\title{
Site C0014
}

\author{
Expedition 331 Scientists $^{2}$
}

\section{Chapter contents}

Background and objectives. ......... 1

Operations................... 1

Lithostratigraphy.............. 3

Biostratigraphy ...............6

Petrology .................. 7

Geochemistry ................9

Microbiology . . . . . . . . . . . . 12

Physical properties .............. 13

References................... 14

Figures................... 17

Tables..................... 55

\section{Background and objectives}

Integrated Ocean Drilling Program (IODP) Site C0014 is located $450 \mathrm{~m}$ east of the main hydrothermal mound chains of the Iheya North field and 350 m east of Site C0013 (see Fig. F3 in Expedition 331 Scientists, 2011a). Site C0014 has a distinct colony of deep-sea clams and a generally rocky seafloor.

Based on a heat flow survey of the entire hydrothermal field (see Fig. F1 in Expedition 331 Scientists, 2011c), Site C0014 is located in a region of relatively low surficial heat flow $\left(1^{\circ}-1.5^{\circ} \mathrm{C} / \mathrm{m}\right)$. Compared with Site C0013, Site C0014 is expected to have a deeper and more moderate hydrothermal mixing zone in the subseafloor. The multichannel seismic (MCS) survey (see Figs. F5 and F6 in Expedition 331 Scientists, 2011a) predicts that the upper part of the sediment column, to 70-80 meters below seafloor (mbsf), consists of well-stratified sequences that are probably pyroclastic deposits interbedded with hemipelagic and hydrothermal sediments. The underlying interval to $120 \mathrm{mbsf}$ seems to be nonstratified pumiceous pyroclastic deposits, and the deepest zone may be volcanic basement.

The scientific objectives for Site C0014 are similar to those for Expedition 331 as a whole, namely, to test for direct evidence of a "subvent biosphere" and to clarify the architecture, function, and impact of subseafloor microbial ecosystems and their relationship to physical, geochemical, and hydrogeologic variations within a mixing zone, in this case one with relatively low hydrothermal input. Preliminary pore water chemistry and microbial community characterization from piston cores that penetrated several meters (J. Ishibashi et al., unpubl. data) suggest a gradual change in microbial activity with increasing depth. Microbial communities appear to be dominated by anoxic methane-oxidizing Archaea and Bacteria, together with typical anaerobic archaeal and bacterial phylotypes often identified in deep-sea sediments. With increasing depth below the seafloor, sulfate in pore water gradually decreases whereas methane increases, possibly supplied by a deeper hydrothermal source.

'Expedition 331 Scientists, 2011. Site C0014. In Takai, K., Mottl, M.J., Nielsen, S.H., and the Expedition 331 Scientists, Proc. IODP, 331: Tokyo (Integrated Ocean Drilling Program Management International, Inc.).

doi:10.2204/iodp.proc.331.104.2011

'Expedition 331 Scientists' addresses.

\section{Operations Arrival at Site C0014}

The transit to Site C0014 from Site C0013 was short, as the sites are only $300 \mathrm{~m}$ apart. The D/V Chikyu arrived during the after- 
noon of 15 September 2010 to conduct a seabed survey. The selected area features a live clam colony and some cool diffuse seafloor seeps. The second guide base landed offset from the clam colony and away from any venting areas on what appeared to be very soft seabed. By early morning on 16 September, we were ready to core the first pilot hole (Table T1; Fig. F1).

\section{Hole C0014A}

Hole C0014A was spudded $7 \mathrm{~m}$ south of the guide base on the morning of 16 September 2010. Fortunately, the remotely operated vehicle (ROV) observed the core barrel drop down from the core bit. Unfortunately, the bit was found to be irretrievable except through a complete pipe trip. Thus ended Hole C0014A after coring to just 4 mbsf.

\section{Hole C0014B}

Surface current conditions required about a mile of drifting before spudding Hole C0014B at $1087.5 \mathrm{~m}$ drilling depth below seafloor (DSF) on the evening of 16 September 2010, $5 \mathrm{~m}$ southwest of Hole C0014A. The first core was a hydraulic piston coring system (HPCS) core shot $3 \mathrm{~m}$ above the seabed and advanced fully. The second core was recovered after advancing $6.5 \mathrm{~m}$ by wash-down. After four good HPCS cores, the liner of the fifth core showed signs of melting, and it was decided to finish the hole on 17 September.

\section{Hole C0014C}

The ROV found a new spudding point $22 \mathrm{~m}$ west of the guide base on the morning of 17 September 2010. Hole C0014C was shot with the HPCS to recover the mudline, after which the Chikyu moved 9 $\mathrm{m}$ south to find a good location to spud Hole C0014D.

\section{Hole C0014D}

Hole C0014D was spudded on 17 September 2010. After another successfully recovered mudline, the second core proved difficult to recover. Pulling up showed that the inner barrel was protruding from the bit, ending Hole C0014D at 16 mbsf.

\section{Hole C0014E}

Hole C0014E was spudded on 17 September 2010, $<1 \mathrm{~m}$ from Hole C0014D, and then drilled to 16 mbsf. Two full-length HPCS cores were recovered, after which coring was stopped at $35 \mathrm{mbsf}$, as we saw little reason to melt more core liner. As the time was approaching for the crew change in Nago Bay, Japan, we decided we had enough pilot holes at Site C0014 and began to move toward Site C0015 to take a few cores at this contingency site until we needed to move to shore.

\section{Hole C0014F}

After returning from the crew change at Nago Bay, we stood by while the R/V Natsushima finished operations in the area. Near midnight on 20 September 2010, we tagged the seafloor at $1088 \mathrm{~m}$ DSF and then shot the HPCS $4 \mathrm{~m}$ above the seabed at Hole C0014F, $5 \mathrm{~m}$ northwest of the guide base. This core was taken as a test of the new aluminum liner, and the hole was abandoned after reaching a depth of $4.2 \mathrm{mbsf}$.

\section{Hole C0014G}

On the morning of 21 September 2010 we finally entered the guide base at Site C0014, intending to shoot three HPCS cores with plastic liners before switching to aluminum liners. The first three HPCS cores took us to 28.2 mbsf with good recovery. The next three cores were shot as HPCS cores with aluminum liners with great success, recovering on average $71 \%$ of the cored interval in decidedly undeformed and unmelted liners. By Core 331-C0014G-6H, reaching 50.2 mbsf after a $3 \mathrm{~m}$ advance, the HPCS was stopped by a hard formation. We switched to the extended shoe coring system (ESCS) and plastic liners until we encountered soft material again. We ended up alternating between the HPCS and ESCS this way until Core 331-C0014G-12H at 66.7 mbsf.

The ESCS system with plastic liners functioned well, despite indications of temperatures well above $200^{\circ} \mathrm{C}$, as the period of no circulation was kept to an absolute minimum.

After Core 331-C0014G-12H, we switched to the extended punch coring system (EPCS). This resulted in generally good recovery for eight cores, reaching 98.2 mbsf with variable recovery (averaging 60\%). After Core 331-C0014G-20T, recovery again became erratic and gradually deteriorated after Core 24T. By Core 331-C0014G-27T, the seals of the inner barrel showed signs of melting. This happened again for Cores 331-C0014G-28T and 29T, which also had issues pressuring up before firing. For the final Core 331-C0014G-30X, we switched to the ESCS and changed to heat-resistant O-rings. Recovery was 0.5 $\mathrm{m}$ for a $9.5 \mathrm{~m}$ advance. We decided that $136.7 \mathrm{mbsf}$ total depth was sufficient to complete the site objectives and left on 24 September to take a couple of cores at Site C0013 before starting casing operations in Hole C0014G. 


\section{Casing and capping Hole C0014G}

The return to Site C0013 was brief, and the Chikyu returned to Hole C0014G on 24 September 2010, preparing to run $5 \frac{1}{2} 2$ inch casing. The casing shoe entered the guide base on the morning of 25 September, but the casing hanger would not go through the wellhead because of a slight incline of the latter. Unlocking the wellhead let the tool through, and, after a trip to surface, the ROV was able to land the cap on the wellhead on the afternoon of 25 September, completing operations at Site C0014.

\section{Lithostratigraphy}

The drilled sequence at Site C0014 comprises interbedded, variably altered, and consolidated volcaniclastic gravel and breccia, as well as hemipelagic mud. Given the location of the site on the upper flank of an active volcanic complex, mass wasting and debris flows are likely to be important sedimentary processes, potentially leading to high rates of redeposition of both hemipelagic and volcaniclastic material. The deeper portion of the rock volume cored has been hydrothermally altered. Differing degrees and styles of hydrothermal alteration form the basis for the division of Site C0014 sediments and lithologies into lithostratigraphic units (Table T2). Unit I, the stratigraphically highest unit, shows little evidence of hydrothermal alteration and comprises a succession of coarse angular woody pumice gravel and hemipelagic mud. Unit I extends to $~ 10-18$ mbsf across Site C0014 (Fig. F2). The contact between Unit I and Unit II is somewhat arbitrarily defined by increasing hydrothermal alteration, which is expressed in drill core by breakdown of pumice texture and mineralogy and bleaching of hemipelagic mud. The nature of the boundary varies in individual cores and may be locally defined by a highangle sharp contact (interpreted as a fault), such as in Section 331-C0014D-2H-3, $130 \mathrm{~cm}$, across which there is a distinct change in alteration intensity. However, in other cores (for example, Sections 331C0014B-2H-6 and 331-C0014G-2H-4 through 2H-5), the increase in alteration intensity is more gradational. Unit II consists of partially consolidated hydrothermally altered mud and hydrothermally altered coarse angular pumice gravel. Clasts of pumice have been devitrified to soft clay that retains its woody texture. Unit II is $12-30 \mathrm{~m}$ thick with a base at 29-45 mbsf. Unit III is characterized by the occurrence of consolidated and often cemented volcanic sediments as lithoclasts within breccia or thin horizons interbedded with hydrothermally altered indurated mud. The greatest thickness of Unit III was en- countered in Hole C0015G from 29 mbsf to the deepest recovered core at 128 mbsf (Fig. F2).

\section{Description of lithostratigraphic units}

\section{Unit I}

Intervals: Sections 331-C0014A-1H-1, $0 \mathrm{~cm}$, to $1 \mathrm{H}-$ CC, $45.5 \mathrm{~cm}$; 331-C0014B-1H-1, $0 \mathrm{~cm}$, to $2 \mathrm{H}-6$, $35.0 \mathrm{~cm}$; 331-C0014C-1H-1, $0 \mathrm{~cm}$, to $1 \mathrm{H}-\mathrm{CC}$, $19.5 \mathrm{~cm}$; 331-C0014D-1H-1, $0 \mathrm{~cm}$, to $2 \mathrm{H}-3,119$ $\mathrm{cm}$; 331-C0014E-1H-0, $0 \mathrm{~cm}$, to $1 \mathrm{H}-2,140.5 \mathrm{~cm}$; $331-\mathrm{C} 0014 \mathrm{~F}-1 \mathrm{H}-1,0 \mathrm{~cm}$, to $1 \mathrm{H}-5,99 \mathrm{~cm} ; 331-$ C0014G-1H-1, $0 \mathrm{~cm}$, to $2 \mathrm{H}-5,117 \mathrm{~cm}$

Depths: Hole C0014A = 0-5.33 mbsf, Hole C0014B $=0-12.12$, Hole C0014C $=0-5.22 \mathrm{mbsf}$, Hole $\mathrm{C} 0014 \mathrm{D}=0-10.45 \mathrm{mbsf}$, Hole C0014E $=16-$ 17.54 , Hole C0014F $=0-4.2$ mbsf, Hole C0014G $=0-15.95 \mathrm{mbsf}$

Lithology: hemipelagic mud and pumice breccia

\section{Sediment types and lithotypes}

Hemipelagic homogeneous mud

Homogeneous gray mud (silty clay to clayey silt) is characterized by abundant microfossils-dominantly intact foraminifers-typical of a hemipelagic sedimentary environment. Dark laminae $(\sim 1 \mathrm{~mm})$ of humic substances and organic debris occur at the top of many sand and silt patches $(1-3 \mathrm{~cm}$ thick) that are intermittently present. Detrital minerals are mostly quartz, feldspar, mica, and minor opaque heavy minerals.

Pumiceous sediments

At Site C0014, coarse angular pumice gravel is predominantly composed of angular clasts of woody pumice, as at Site C0015. Woody pumice exhibits tubular structure, with tubes $\sim 2 \mathrm{~mm}$ in cross section. These tubes give the pumice unique sedimentological properties, as cooling of volcanic gases within the tubes helps them to imbibe water rapidly and thus reduce the buoyancy of clasts. This mechanism probably causes woody pumice to settle near its location of effusion (Kato 1987; Fiske et al., 2001). For clastsupported gravel without a significant matrix component, the unconsolidated nature of deposits makes it difficult to distinguish sedimentary contacts between individual pumice beds. Compared with gravel at Site C0015, however, a significant matrix component is frequently present at Site C0014, which helps to delineate bedding. Matrix components are of two types: (1) hemipelagic mud and (2) silt- to grit-sized, poorly sorted angular quartz, volcanic glass, and pumice fragments (acicular volcanic glass). The bases of many pumice breccia intervals contain a coarse sand matrix of pumice frag- 
ments with a minor but significant mud fraction, whereas the top of pumice gravel typically contains a mud matrix that grades upward into an overlying mud unit.

Pumiceous grit with poorly sorted clasts of angular quartz, volcanic glass, and pumice fragments (acicular volcanic glass) comprises a distinct interval in Hole C0015D (interval 331-C0015D-1H-3, $26 \mathrm{~cm}$, to $1 \mathrm{H}-4,140 \mathrm{~cm}$ ). Lithoclasts of pumice are present but are a very minor component in this interval. Microfossils are generally absent in pumice-rich units. When they are present in gravel matrix or grit, they are typically weathered and broken, indicating that the microfossils have been reworked.

\section{Correlation within Unit I}

Sedimentary logs were used to attempt correlation of pumice horizons within Unit I. All holes at Site C0014 are located in a hollow with $\sim 2 \mathrm{~m}$ of relief from the highest Hole C0014B to the lowest Holes C0014F and C0014G. The bases of debris flows and mud units were used as correlative horizons to assess continuity of pumice layers across the hollow. A general thickening of individual pumice gravel units traceable between holes corresponds to a deepening of the hollow and a downslope location of the drill holes. The slope is a transient depocenter, and the thickest pumice gravel deposits likely accumulated through the amalgamation of successive debris flows, screes, and talus deposits. Resedimenting of pumice and mud is highly likely, and presumably sediments were deposited farther downslope.

\section{Unit II}

Intervals: Sections 331-C0014B $2 \mathrm{H}-6,35.0 \mathrm{~cm}$, to $5 \mathrm{H}-\mathrm{CC}, 22.5 \mathrm{~cm}$; 331-C0014D-2H-3, $119 \mathrm{~cm}$, to $2 \mathrm{H}-\mathrm{CC}, 35.0 \mathrm{~cm} ; 331-\mathrm{C} 0014 \mathrm{E}-1 \mathrm{H}-3,0 \mathrm{~cm}$, to $2 \mathrm{H}-6,62 \mathrm{~cm}$; 331-C0014G-2H-6, $0 \mathrm{~cm}$, to $4 \mathrm{H}-1$, $37.5 \mathrm{~cm}$

Depths: Hole C0014B = 12.12-45.28 mbsf, Hole $\mathrm{C} 0014 \mathrm{D}=10.45-15.42 \mathrm{mbsf}$, Hole C0014E = 17.5-30.6 mbsf, Hole C0014G = 16.2-28.57 mbsf

Lithology: hydrothermally altered mud, mud, and sand with detrital hydrothermal component

\section{Sediment types and lithotypes}

Hydrothermally altered mud

Hydrothermally altered mud from Unit II is light to medium gray and frequently mottled. Most mud layers are interbedded with hydrothermally altered coarse angular pumice gravel over depth intervals of $\sim 30 \mathrm{~cm}$. Mottled mud is generally stiff and somewhat sticky. Illite, quartz, and Mg chlorite are the predominant minerals, along with widely distributed mica flakes. Silt, sand, and gravel, both angular and poorly sorted, are present and, in a few instances, form small beds as thick as $10 \mathrm{~cm}$. In one instance, a thin bed of sand has loaded into underlying mud (interval 331-C0014G-3H-3, 26-27 cm; 21 mbsf).

Toward the base of Unit II, it becomes increasingly difficult to visually distinguish hydrothermally altered mud from hydrothermally altered pumice gravel, although this is not always the case. Hydrothermally altered pumice gravel and grit are whitish to medium gray and comprise clasts of variably devitrified pumice, often with a woody fibrous structure preserved (Fig. F3). Toward the base of Unit II, primary clastic textures are increasingly lost, replaced by white in gray or dark gray in light gray mottling. Devitrified pumice clasts are no longer rigid and deform easily, even when structures are well preserved. Some units lack matrix support and comprise horizons of loosely consolidated clasts of mud (Fig. F3). More typically, hydrothermally altered pumice-breccia is matrix supported in hydrothermally altered mud, and a progression can be seen from the top of the unit at 10 mbsf to the base of the unit at $\sim 30 \mathrm{mbsf}$, where relict pumice clasts are replaced by intense oblate mottling and unconsolidated horizons are scarce.

\section{Unit III}

Intervals: Sections 331-C0014E-2H-6, $62 \mathrm{~cm}$, to $2 \mathrm{H}-\mathrm{CC}, 17.5 \mathrm{~cm}$; 331-C0014G-4H-1, $37.5 \mathrm{~cm}$, to 30X-CC, $19.5 \mathrm{~cm}$

Depths: Hole C0014E $=30.6-34.78 \mathrm{mbsf}$, Hole C0014G $=28.57-127.87 \mathrm{mbsf}$

Lithology: silicified volcanic sediments (either matrix silicified or clasts and matrix silicifed), hydrothermally altered mud, mud, and sand with detrital hydrothermal component, as well as other volcaniclastic sedimentary rock

\section{Sediment types and lithotypes}

Hydrothermally altered mud and volcaniclastic sediments

The predominant lithologies in Unit III are gray, mottled, hydrothermally altered mud as described for Unit I, with horizons of well-cemented clasts of volcanic breccia. The breccia includes volcanic clasts other than woody pumice; both amygdaloidal vesicular lavas and devitrified lapilli in a silica-rich matrix were observed in addition to cemented pumice breccia (Fig. F4). Clasts of pumice breccia in this lithology comprise fragments typically $<1 \mathrm{~cm}$ across, as opposed to the large pumice clasts observed in Unit I. These components probably derive from a source that has gone through different sedimentation cycles 
than the pumice in Units I and II, where the pumice was broken into smaller fragments. Some clasts of volcanic rock were observed in interpreted "right way up" positions interbedded with $5-10 \mathrm{~cm}$ thick layers of hydrothermally altered mud, whereas others were found floating in a hydrothermal mud matrix. How much of this difference is a result of drilling disruption is not always obvious, although it is clear that both poorly consolidated mud and well-cemented volcaniclastic units were cored.

Mineral cements were identified by X-ray diffraction (XRD) as quartz and minor anhydrite (Fig. F5), but cementing is intermittent and absent from some mud layers, many of which were disrupted by drilling. Cemented volcaniclastic breccia horizons were encountered below 30 mbsf in Holes C0015E, C0015B, and C0015G. Anhydrite appears as a rare vein filling and cementing phase below $60 \mathrm{mbsf}$, but cementing is still intermittent and in many instances is absent from mud units even below the onset of anhydrite vein formation.

\section{Lithology and velocity structure}

Figure F2 correlates units between holes for Site C0014. A wide range of $P$-wave velocities are observed at Site C0014, ranging from values typical of unconsolidated sediment to velocities closer to those of igneous and crystalline rocks. A general trend of subtly increasing velocity downhole is seen, consistent with the increasing degree of induration and lithification seen within Unit III at Site C0014.

\section{Grain size distribution}

Mean grain sizes of matrix sediment from Holes C0014A and C0014B vary from $3.35 \Phi$ to $7.83 \Phi$ and from $2.64 \Phi$ to $7.78 \Phi$, respectively. Hole C0014A sediments comprising mud or pumiceous lithotypes have distinctly different grain sizes, with a clear boundary occurring at $\sim 4.3$ mbsf (Fig. F6A; Table T3). Hemipelagic mud in Unit I is characterized by fine-grained sediments in which the clay fraction is $>25 \%$ and the sand fraction ranges from $0 \%$ to $\sim 10 \%$. In pumiceous units, even the matrix consists mostly of sandy sediment, with a clay fraction $<15 \%$ and a sand fraction $>50 \%$. Similarly, sediments in Hole C0014B show large downhole variations in grain size patterns between different depositional units (Fig. F6B). The hemipelagic mud has a similar grain size distribution to that of Hole C0014B, with a clay proportion $>25 \%$ and a sand fraction $<1 \%$. The sand and silt units in pumiceous horizons are composed primarily of silty sand, with a clay fraction of $<10 \%$ and a sand fraction of $20 \%-74 \%$.
The standard deviation of the grain sizes reveals that measured sediments from Hole C0014A are poorly sorted to very poorly sorted, whereas those from Hole C0014B are very well sorted to very poorly sorted. Depositional units in both holes show variable skewness, among which all hemipelagic mud skews coarse and all pumiceous and hydrothermally altered units skew fine. Kurtosis measurements suggest that grain size patterns of hemipelagic mud in both holes are platykurtic, whereas pumiceous units are mesokurtic in Hole C0014A and mesokurtic to leptokurtic in Hole C0014B. On the classic ternary diagram of Folk and Ward (1957) for grain size discrimination, sediments in both holes are classified mostly as silt within the hemipelagic mud lithotype and silty sand to sandy silt in the pumiceous and hydrothermally altered sediments (Fig. F7).

Grain size distribution patterns further discriminate different sediment origins (Fig. F8), showing three significantly different types. The uppermost part of Unit I contains hemipelagic mud that exhibits similar grain size patterns in Holes C0013F, C0014A, and $\mathrm{C} 0014 \mathrm{~B}$, with one dominant peak at $\sim 7.5 \Phi$, which is probably diagnostic of the deposition of normal hemipelagic terrigenous sediment in the central Okinawa Trough. Hydrothermal grit (hydrothermally altered sand and gravel in Hole C0014B) has distinctly different grain size patterns from hemipelagic mud: it shows very fine skew, mostly mesokurtic to leptokurtic, and has major peaks at $1 \Phi$ to $\sim 2.5 \Phi$. In comparison, hydrothermal mud with pumiceous clasts or mud-supported pumiceous gravel generally have variable grain size patterns with several dominant peak percentages. The grain size patterns of these sediments vary between typical hemipelagic mud and hydrothermal grit (Fig. F8). Although we used the term mud for operational purposes during visual core description, it is clear that grain size analysis has considerable potential for discriminating the provenance of fine-grained sediments.

Comparison of grain size distributions between Holes C0013F, C0014A, C0014B, and piston Core DGKS9604, which were all taken from the central Okinawa Trough, shows that the uppermost hemipelagic mud in each hole has a similar mean grain size of $\sim 7 \Phi$ (Fig. F9). Nevertheless, it is impossible at present to make a detailed correlation between these sediments because of the lack of chronostratigraphy for Holes C0013F, C0014A, and C0014B coupled with variable sediment accumulation rates in the central Okinawa Trough. The chronostratigraphy of Core DGKS9604 is well established by $11{ }^{14} \mathrm{C}$ dates and oxygen isotope measurements of planktonic and benthic foraminifers, which indicate that $2.05 \mathrm{~m}$ of mud 
has been deposited during the Holocene at this location (Yu et al., 2009; Dou et al., 2010). Hemipelagic mud is 4.3 to $8.0 \mathrm{~m}$ thick in Holes C0014A and C0014B but $<1.0 \mathrm{~m}$ thick in Hole C0013F (Fig. F9), suggesting much higher Holocene sedimentation rates in Holes C0014A and C0014B. The depths of the seafloor at Holes C0014A (1059.5 meters below sea level [mbsl]) and C0014B (1059.0 mbsl) are almost the same as at Hole C0013F (1059.8 mbsl) and are much deeper than at Core DGKS9604 (766 mbsl). Different sediment accumulation rates during the Holocene at these locations could readily be caused by variation in sediment supply, particularly local volcaniclastic input, local topography, and ocean circulation patterns, and deserves more in depth investigation.

\section{Biostratigraphy}

At depths shallower than $\sim 10$ mbsf, core catcher samples from Site C0014 generally contain microfossils. Paleontological (PAL) samples from core catchers at depths greater than $\sim 10$ mbsf contain no microfossils (Table T4). Core catcher samples also include glass at shallow depths near the seafloor; at intermediate depths they contain pumice clasts and fragments with varying amounts of weathered white clay, transitioning to gray clay above a second white clay-anhydrite zone near the bottom of the deepest Hole C0014G. Microfossils are also abundant in sediment samples from Hole C0014A at 0.01 mbsf, Hole C0014B at 0.06 and 6.04 mbsf, and Hole C0014F at 2.04 mbsf. In contrast, no microfossils were observed in any material from Holes C0014C, C0014D, C0014E, or C0014G (Table T5; Fig. F10).

The foraminifers observed are dominated by planktonic species, suggesting either that there is a large input of foraminifers from the overlying water column or that the environment surrounding Site C0014 is preferentially dissolving benthic foraminifers, which are typically more prominent in South China Sea samples (Saidova, 2007). Although some fragmentation occurred, preservation of foraminiferal microfossils is generally good, with little or no evidence of dissolution and/or overgrowth; diagnostic characteristics are preserved, and many species can be identified. Consistent with good preservation, microfossils from Site C0014 represent foraminifers that are observed in modern surface waters. The greater relative abundance of Neogloboquadrina pachyderma dextral (e.g., right-hand coil sense) versus the sinistral (e.g., left-hand coil sense) variant demonstrates the influence of the warmer Kuroshiro Current at this site (Bandy, 1960; Ericson, 1959).
A sediment sample from Hole C0014A at $4.1 \mathrm{mbsf}$ contained a large fraction of pyritized foraminifers (Fig. F11A-F11C). These pyritized foraminifers are extremely well preserved, allowing species identification. Pyritization in these samples differs from those in previous reports with respect to infilling of the foraminiferal tests and the preservation of pseudomorphs (Kohn et al., 1998). The broken, pyritized foraminifers are hollow (Fig. F11C), highlighting complete replacement of the carbonate wall with fine-grained iron sulfide. Preliminary observations suggest that they are coated in fine-grained framboidal pyrite (Fig. F11E); at high resolution, framboids were shown to consist of well-ordered acicular iron sulfide crystals (Fig. F11F). Smaller foraminifers are also pyritized within more classically structured framboidal pyrite aggregates (Fig. F12), suggesting that the foraminiferal carbonate tests were controlling iron sulfide crystallization during pyrite replacement (Fig. F11).

Only a few coccolithophorids were recovered at Site C0014. One sample from Hole C0014A at $0.01 \mathrm{mbsf}$ was processed as a surface (i.e., modern) sample (Table T6; Fig. F13A-F13C) and compared to a core catcher sample from Hole C0014B from 7.0 mbsf. The coccolithophorid diversity of this deeper sample is generally consistent with the shallow modern mud sample (Winter and Siesser, 1994; Raffi et al., 2006), as Emiliania huxleyi is the predominant species. Coccolith preservation at $\sim 7.09$ mbsf is poor (Fig. F13D). Damage to coccoliths at such a shallow depth suggests they may have been reworked or deposited under more energetic conditions; in addition, pore water at this depth is corrosive to coccolithophorids (see "Geochemistry").

Small numbers of radiolarians were observed in the 63-150 $\mu \mathrm{m}$ sieved fraction recovered from $0.01 \mathrm{mbsf}$ in Hole C0014A. Radiolarian fragments were commonly observed in samples that contain abundant foraminifers (Fig. F14).

Based on their relatively high abundance and enhanced preservation, foraminifers were targeted for paleontological examination during Expedition 331. The restriction of microfossils to one or two samples (when they occur at all) and to only the upper few meters of sediment limits biostratigraphic interpretation at this site using core catcher material. The recovery of as much as $5 \mathrm{~m}$ of sediment containing foraminifers from Holes C0014A and C0014B, along with the $50 \mathrm{~cm} / \mathrm{k} . \mathrm{y}$. average sedimentation rate described by Chang et al. (2008), suggests a maximum of 10 k.y. of sediment accumulation at Site C0014. This estimate does not account for the contribution of pumice clasts and fragments (Table T4), which 
represent a major part of the sediment accumulating in the upper stratigraphic units at this site. The microfossils may therefore be even younger (i.e., essentially modern and encompassing only the earliest paleontological unit described by Xiang et al., 2003).

\section{Petrology}

Seven holes were drilled at Site C0014, which was targeted at a low heat flow site $\sim 0.5 \mathrm{~km}$ east of the main high-temperature chimneys of the Iheya North hydrothermal field (Takai et al., 2010). Of these seven holes, three (Holes C0014A, C0014C, and C0014F) were drilled no deeper than $6.5 \mathrm{mbsf}$ and did not encounter significant hydrothermal alteration. The four deeper holes-Holes C0014B (cored interval 0.0-44.5 mbsf), C0014D (cored interval 0.0$16.0 \mathrm{mbsf}$ ), C0014E (cored interval 16.0-35.0 mbsf), and C0014G (cored interval 0.0-136.7 mbsf)-penetrated a sequence of hydrothermal alteration that is broadly consistent with the alteration assemblages seen at Site C0013. Although trace concentrations of sulfide minerals, most commonly pyrite, were present in almost all cores recovered from Site C0014, no significant mineralization was encountered.

The following description of hydrothermal alteration and mineralization from Site C0014 is based primarily on visual descriptions of cores from Holes C0014A-C0014G, supplemented by XRD analyses, scanning electron microscope (SEM) imaging, and energy dispersive spectrometry (EDS) characterization of representative samples. Most of the rocks cored at the site are composed of very fine grained material. With the exception of pumiceous volcanic glass, anhydrite, quartz, and sulfide minerals, most mineralogical determinations were made or confirmed using XRD analysis. This is particularly true of $\mathrm{Mg}$ chlorite, talc, kaolinite, and muscovite within the altered sequence.

The seven holes at Site C0014 were drilled within a $15 \mathrm{~m} \times 15 \mathrm{~m}$ area and over a change in seafloor elevation of $2 \mathrm{~m}$ (Fig. F1), meaning that they can be considered to represent a single stratigraphic hole for petrographic interpretation.

\section{Overview of hydrothermal alteration and mineralization at Site $\mathrm{C} 0014$}

Hydrothermal alteration and mineralization at Site C0014 can be spatially divided into three assemblages that exhibit broadly consistent vertical distribution beneath the seafloor (Fig. F15):

1. From 0 to $8-10$ mbsf, hemipelagic ooze and pumiceous volcaniclastic sediments exhibit little evidence of hydrothermal alteration.
2. From $\sim 8-10$ to $\sim 25-30$ mbsf, the sedimentary sequence is hydrothermally altered to pale gray mottled clay, with detrital quartz and muscovite the dominant phases detected by XRD, along with alteration products illite/montmorillonite and, less commonly, kaolinite. The uppermost 1-2 $\mathrm{m}$ of this zone shows a gradational increase in alteration intensity, with the replacement of the fine-grained matrix occurring at shallower depths than that of coarser pumiceous clasts. Unlike Site C0013, no significant anhydrite is associated with illite/montmorillonite alteration at Site C0014, implying less direct seawater input into the system at this site. Pyrite occurs in trace amounts as fine-grained disseminations and as very rare coarser veins throughout the sequence.

3. At depths below $\sim 25-30$ mbsf to the maximum drilling depth of 136.7 mbsf in Hole C0014G, XRD indicates that $\mathrm{Mg}$ chlorite becomes an important alteration phase, irrespective of lithology. Unlike Site C0013, detrital muscovite persists within this alteration zone, as does quartz. Anhydrite is present, mostly in millimeter-scale irregular veinlets with halite, below $57 \mathrm{mbsf}$ in Hole C0014G but in much lower abundance than was seen at Site C0013. Pyrite occurs in trace amounts as fine-grained disseminations and very rare coarser veins throughout the sequence.

\section{Near-surface unaltered sediment}

As noted above, the sequence of mud, sand, and pumiceous gravel cored in the three shallow holesHoles C0014A (0-6.5 mbsf), C0014C (0-6.5 mbsf), and C0014F (0-4.2 mbsf)-shows no evidence of hydrothermal alteration. Additionally, the uppermost portions of Holes C0014B (0-10.4 mbsf), C0014D (0$8.4 \mathrm{mbsf})$, and C0014G (0-7.9 mbsf) comprise similar unaltered material.

Sediment from just below the seafloor is a combination of pumiceous felsic volcaniclastic material, bioclastic fragments, and hemipelagic sediment. Based on XRD analyses (Table T7), quartz, muscovite, and calcite are the most abundant phases, with opaline silica, crystobalite, halite, feldspars, and chlorite also commonly detected. Fine-grained disseminated and framboidal pyrite (interpreted to be formed primarily by microbial processes) was also seen in most samples, both visually and by XRD.

Although there is no evidence of hydrothermal alteration in the near-surface sediments at Site C0014, the top few centimeters of Holes C0014F and C0014G show weak oxidation, expressed as brown coloration. In addition, the lower part of Hole 
C0014C, below $\sim 1.5$ mbsf, shows slight green staining of pumiceous gravel, interpreted to be glauconitic "greensand," which implies an anoxic marine environment that is rich in organic detritus and low in sedimentary input (Odin, 1988). However, this interpretation is tentative, and no evidence of glauconite was found in XRD samples from the interval.

\section{Illite/montmorillonite alteration}

At the base of the unaltered sedimentary sequence in Holes C0014B, C0014D, and C0014G, a gradation toward increasing hydrothermal alteration is observed over a distance of $1-5 \mathrm{~m}$ in coarse pumiceous sediments. At the top of this zone, pumice clasts show incipient devitrification, and the fine-grained matrix is partially altered to pale clay (Fig. F16A). With increasing depth, pumice clasts increasingly lose their original texture and clay alteration becomes more intense (Fig. F16B, F16C). When fully altered, there is no textural difference between the remnant pale pseudoclasts after pumice and the darker clay that surrounds them (Fig. F16D). Hole C0014E, which began coring at 16.0 mbsf, commences in strongly altered material.

XRD analyses reveal an assemblage of quartz and muscovite, with variable occurrence of illite/montmorillonite and much less widespread kaolinite (Table T7). Illite/montmorillonite is detected in Holes C0014B and C0014D-C0014F, whereas kaolinite is only detected in Holes C0014B and C0014D and is significantly less abundant than at Site C0013.

It is likely that much of the quartz and muscovite within the kaolinite-illite/montmorillonite alteration zone at Site C0014 is detrital in origin, as both phases are abundant in fresh sediments at the site. The intensity of alteration, although estimated visually as "very high" (defined as $>80 \%$ alteration products) in the lower parts of the interval, based primarily on the destruction of pumice clasts and the pale color of the sediment, is clearly lower than that observed at Site C0013. Additionally, the absence of anhydrite in this alteration zone at Site C0014 is suggestive of a much lower degree of fluid-rock interaction than at Site C0013.

The base of the illite/montmorillonite alteration zone at Site C0014 is defined via XRD by the appearance of $\mathrm{Mg}$ chlorite within the alteration assemblage. It occurs at 29.9 mbsf in Hole C0014B, 25.5 mbsf in Hole C0014E, and 28.2 mbsf in Hole C0014G. Hole C0014D, which was cored to a total depth of 16 mbsf, ends in illite/montmorillonite-altered material.

There is little mineralization associated with illite/ montmorillonite alteration at Site C0014. Sulfide is mostly limited to fine-grained disseminated pyrite that occurs at low abundances (typically visually estimated at $<<1 \%$ ) throughout the sequence. A handful of slightly coarser pyrite-sphalerite veins, up to 2 $\mathrm{mm}$ in width, were also observed. A handful of XRD traces were also interpreted to indicate covellite and "copper sulfide" (Table T7), although none was identified visually in core.

\section{Mg chlorite alteration}

As was noted above, $\mathrm{Mg}$ chlorite-bearing alteration persists from $~ 25-30$ mbsf to the maximum depth of drilling in Holes C0014B (44.5 mbsf), C0014E (35.0 mbsf), and C0014G (136.7 mbsf, with very poor recovery below $\sim 115 \mathrm{mbsf}$ ).

A broad diversity of lithologies is present within the $\mathrm{Mg}$ chlorite-altered interval (see Site C0014 visual core descriptions in "Core descriptions"), including unconsolidated soft pale gray clay; heavily indurated dark gray clay that is verging on mudstone; hard fragmentally textured volcanic clasts featuring pale clay-altered fragments in a dark quartz-rich matrix; and sugary pale gray silicified fragmentally textured, flow-banded, and pumiceous volcanic clasts in a soft greenish-gray clay matrix. Despite the wide lithological diversity, the mineralogical assemblage shows remarkable consistency throughout the drilled sequence. As in the overlying kaolinite-illite/ montmorillonite-altered interval, quartz and muscovite are present throughout the $\mathrm{Mg}$ chlorite-altered interval at Site C0014 and likely reflect the primary mineralogy of the volcaniclastic and pelagic sediments that comprised the sequence prior to alteration. $\mathrm{Mg}$ chlorite is present in almost all samples analyzed (Table T7). Anhydrite is found only below depths of $\sim 57$ mbsf in Hole C0014G and in low abundances. Although a small number of coarse 1 $\mathrm{cm}$ crystals were noted, most anhydrite occurs in irregular submillimeter-scale veinlets with halite. SEM imaging of a coarse anhydrite crystal (Fig. F17A) shows corrosion of the crystal surface, indicating partial dissolution of the mineral following precipitation, presumably by fluids at temperatures $<150^{\circ} \mathrm{C}$ (Bischoff and Seyfried, 1978).

As was noted for the overlying kaolinite-illite/montmorillonite alteration, the lack of significant concentrations of anhydrite at Site C0014 is in stark contrast to Site C0013, where anhydrite is a major component in the $\mathrm{Mg}$ chlorite alteration zone. This difference is interpreted to reflect a relative lack of direct seawater influence on hydrothermal alteration at Site C0014.

Little mineralization is associated with $\mathrm{Mg}$ chlorite alteration at Site C0014. Sulfide is mostly limited to fine-grained disseminated pyrite that occurs at low 
abundances (typically visually estimated at $<<1 \%$ ) throughout the sequence. A handful of slightly coarser pyrite-sphalerite veins, up to $2 \mathrm{~mm}$ in width, were also observed, and 1\% euhedral pyrite is also associated with the rare coarse anhydrite veining (Fig. F17B). In the lower part of the sequence, chalcopyrite was also identified visually in Cores 331C0014G-24T (hosted in a vein with sphalerite and galena) (Fig. F18) and 331-C0014G-30X (disseminated in siliceous altered volcanic fragments, with pyrite). A handful of XRD traces were also interpreted to indicate covellite and "copper sulfide" (Table T7), although none was identified visually in core.

\section{Interpretation of alteration at Site C0014}

Hydrothermal alteration at Site C0014 shows a change with increasing depth from illite/montmorillonite to $\mathrm{Mg}$ chlorite-bearing rocks. This is similar to the change from kaolinite-muscovite to $\mathrm{Mg}$ chlorite alteration seen at Site C0013. As discussed in "Petrology" in Expedition 331 Scientists (2011c), this transition is consistent with the generally accepted compositional evolution of upwelling hydrothermal fluids in seawater-dominated subseafloor systems (Seyfried et al., 1999), so it is likely that the alteration observed at Site C0014 was produced by a single hydrothermal event.

Compared with Site C0013, the predominance of illite/montmorillonite over kaolinite at Site C0014 and the absence of native sulfur at shallow depths imply higher fluid $\mathrm{pH}$ for the altered sequence at Site C0014, which is consistent with an absence at Site C0014 of high-temperature $\mathrm{H}_{2} \mathrm{~S}$-rich fluids that form sulfide chimneys in the Okinawa Trough (cf. Marumo and Hattori, 1999).

Significantly, transitions in alteration mineralogy occur at much greater depth at Site C0014 than at Site C0013, which is closer to current hydrothermal venting, consistent with the lower temperature gradient observed at the more distant site. As was discussed for Site C0013, temperature estimation is difficult, based on phyllosilicate and clay assemblages. Illite in particular may be stable over a very broad temperature range from $<100^{\circ} \mathrm{C}$ to $\sim 300^{\circ} \mathrm{C}$ (Srodon and Eberl, 1984), whereas, as previously noted, $\mathrm{Mg}$ chlorite implies alteration temperatures of $220^{\circ}-$ $300^{\circ} \mathrm{C}$ (Browne, 1978; Árkai, 2002) below 25 mbsf.

Anhydrite is much less abundant at Site C0014 than Site C0013, and primary volcanosedimentary mineralogy is partially preserved throughout the altered sequence, implying a significantly lower fluid flux than at Site C0013. This observation is consistent with the interpretation that Site C0013 represents a site of recent high-temperature discharge, whereas Site C0014 is a "background" location within the hydrothermal system at Iheya North Knoll.

\section{Geochemistry}

\section{Interstitial water}

A total of 75 whole-round samples were processed at Site C0014 from four different holes (Table T8). Routine samples were collected immediately above or below whole rounds dedicated for microbiology at a frequency of about one sample per $1.5 \mathrm{~m}$ section. We squeezed whole rounds at the laboratory temperature of $\sim 20^{\circ} \mathrm{C}$ rather than at in situ temperature. Depth profiles show discrete layering and large lateral heterogeneity within the uppermost $45 \mathrm{mbsf}$ that was sampled by multiple holes. Lateral variation is especially evident within the uppermost 9 mbsf, especially for those chemical species that are most influenced by diagenetic reactions involving organic matter, such as sulfate and alkalinity, but also for those involved in hydrothermal reactions, such as $\mathrm{K}$ and $\mathrm{Ca}$.

\section{Layering in pore water profiles}

Profiles of dissolved $\mathrm{Mg}$ and $\mathrm{Na}$ show stepwise decreases with depth in Holes C0014B and C0014D between $\sim 9$ and 13 mbsf and in Hole C0014E at $\sim 28-31$ mbsf (Fig. F19). As both $\mathrm{Mg}$ and $\mathrm{Na}$ are taken up into alteration minerals at rates that increase with temperature (e.g., You et al., 1996; You and Gieskes, 2001; Gieskes et al., 2002), we interpret these stepwise decreases as being generated by the presence of discrete less permeable layers within more permeable sediment. The stepwise decreases in $\mathrm{Mg}$ and $\mathrm{Na}$ would then result either from removal of $\mathrm{Mg}$ and $\mathrm{Na}$ into alteration minerals within the deeper more permeable layers, most likely into smectite at the prevailing temperatures of $45^{\circ}-132^{\circ} \mathrm{C}$, or by lateral transport of $\mathrm{Mg}$ - and Na-depleted hydrothermal solutions into these layers from elsewhere. The two relatively impermeable layers inferred from the pore water profiles, at $\sim 9-13$ and 28-31 mbsf, are both defined by higher density and lower porosity relative to the adjacent sediment (see "Physical properties"). Within these layers the concentrations of $\mathrm{Mg}$ and $\mathrm{Na}$ appear to be controlled by diffusion between the overlying and underlying more permeable layers. The low-permeability layer inferred at 9-13 mbsf also causes stepwise changes in $\mathrm{K}, \mathrm{Ca}$, sulfate, and ammonium that show up as steep gradients in the concentrations of these species over this interval (Fig. F19). The intervening, more permeable layers are characterized by nearly uniform $\mathrm{Mg}$ concentrations: the upper layer at 0-9 mbsf approximates sea- 
water, the middle layer at $13-28$ mbsf has intermediate concentrations of $14-18 \mathrm{mM}$, and the deeper layer below $31 \mathrm{mbsf}$ has low concentrations of 4-11 $\mathrm{mM}$. The profile for Hole C0014G is more complex, indicating that the upper low-permeability layer is laterally discontinuous, but this hole does display a steep $\mathrm{Mg}$ gradient roughly within the zone of the deeper less permeable layer, as does Hole C0014E (Fig. F19).

Layers defined by the pore water profiles correspond to changes in alteration intensity and mineralogy within the sediment (see "Petrology"). The uppermost zone at 0-9 mbsf, which is occupied mainly by seawater that has been more or less affected by organic matter diagenesis, lies between the bottom water temperature of $4.5^{\circ}$ and $16^{\circ} \mathrm{C}$, as measured in Hole C0014G, to $33^{\circ} \mathrm{C}$, as measured in Holes C0014C, C0014D, and C0014F. Sediment in this layer is visually estimated to contain $<2 \%$ alteration minerals. The next deeper layer, at 13-28 mbsf, presently lies at $45^{\circ}-90^{\circ} \mathrm{C}$ and is altered to illite/montmorillonite, kaolinite, and pyrite. The next deepest layer, from 31 to $42 \mathrm{mbsf}$, presently lies at $99^{\circ}-132^{\circ} \mathrm{C}$ and is altered to $\mathrm{Mg}$ chlorite, with disseminated pyrite. As $\mathrm{Mg}$ chlorite forms only above $220^{\circ}-300^{\circ} \mathrm{C}$ (Browne, 1978; Árkai, 2002), this layer was certainly hotter in the past, possibly explaining its relative paucity of microbial life. A third less permeable layer, which is defined by its physical properties in Hole $\mathrm{C} 0014 \mathrm{~B}$, lies at $42-44 \mathrm{mbsf}$ and $132^{\circ}-138^{\circ} \mathrm{C}$ and separates a vapor-rich permeable layer above from a brine-rich layer below, as discussed below. The present temperature gradient measured at Site C0014 increases nearly linearly from the ocean bottom water temperature at this site of $4.5^{\circ} \mathrm{C}$ to $145^{\circ} \mathrm{C}$ at $47 \mathrm{mbsf}$ in Hole C0014G and then increases abruptly over only $3 \mathrm{~m}$ to $>210^{\circ} \mathrm{C}$ at $50 \mathrm{mbsf}$. These higher temperatures are consistent with the observed alteration to Mg chlorite.

Within the uppermost layer at $0-9$ mbsf there is great variation from hole to hole for those chemical species that are most influenced by diagenetic reactions involving organic matter, including sulfate (Fig. F20), alkalinity, phosphate, silicon (Fig. F21), ammonium (Fig. F22), and methane (Fig. F23). Holes C0014B and C0014D both show large and complementary spikes in alkalinity and sulfate within this interval, but at different depths. These profiles indicate rapid reduction of seawater sulfate, coupled with oxidation of organic matter to dissolved carbonate (alkalinity), within discrete layers. Ca, K (Fig. F19), Li, Rb, B (Fig. F24), Ba (Fig. F25) and ammonium all show a pronounced spike at $6 \mathrm{mbsf}$ that likely comes from lateral intrusion of a hydrothermal solution. The effects of both reaction and injec- tion are diluted, in turn, by lateral intrusion of seawater within this uppermost layer, especially at 9 mbsf.

Within the middle permeable layer at 12-28 mbsf are small and regular decreases in $\mathrm{Mg}, \mathrm{Na}$, and $\mathrm{Na} / \mathrm{Cl}$ and increases in $\mathrm{K}$, $\mathrm{Ca}$ (Fig. F19), Cl, Br, ammonium (Fig. F22), and $\mathrm{Br} / \mathrm{Cl}$ with depth. Sulfate, alkalinity, dissolved inorganic carbon, and Si are nearly constant, as is $\mathrm{pH}$, which ranges from 6.4 to 7.0 over this depth interval (Table T8). A pair of sharp methane peaks in Hole C0014B, similar to the one at $5.6 \mathrm{mbsf}$ in the layer above, exactly bound this middle layer; they lie so close to its upper and lower edges that it is not obvious whether they originate within the permeable layer or within the impermeable caprocks we have inferred to bound it above and below. Hydrogen does not exceed $1 \mu \mathrm{M}$ at depths shallower than 36 mbsf.

Below the deeper caprock at 28-31 mbsf we sampled a vapor-rich zone which extends from $\sim 29$ to $42-48$ mbsf (gray shading, Fig. F22; sampling density precludes a more precise estimate of depth at the base). Chlorinity begins to decrease at the top of the lower caprock we inferred from the $\mathrm{Mg}$ profile. The vaporrich zone is characterized by low chloride, bromide, sulfate, $\mathrm{Na}$ and $\mathrm{Na} / \mathrm{Cl}, \mathrm{Mg}$, and relatively low alkalinity. It displays relatively high $\mathrm{pH}$ in the range 6.77.4; high $\mathrm{K}, \mathrm{Si}$, ammonium, and $\mathrm{Br} / \mathrm{Cl}$ (to 1.86); and an increase in hydrogen to concentrations as high as $1 \mathrm{mM}$, which persists to the deepest sample at 127 mbsf but is likely an artifact of reaction with the aluminum core liners we used for coring at high temperatures (Fig. F26). Such vapor-rich fluids are seen throughout this region in association with high-temperature hydrothermal venting (e.g., Kawagucci et al., 2011; Suzuki et al., 2008). At Site C0014 the vapor-rich zone is weakly mineralized and the recovered cores were especially gas-rich.

Below the bottom of the vapor-rich zone at $42-48$ mbsf we encountered a brine, with chlorinity up to $620 \mathrm{mM}$ and elevated $\mathrm{Br} / \mathrm{Cl}$ that is as high as 1.79. As noted earlier, this brine is separated from the vaporrich zone above by a high-density, low-porosity layer at $42-44$ mbsf. High alkalinity $(10 \pm 5 \mathrm{mM})$ and ammonium (1-1.5 mM) persist in the brine. Sulfate ranges from 4 to $21 \mathrm{mM}$ and Ca from 22 to $54 \mathrm{mM}$, but both may be affected by dissolution of anhydrite during core processing, as anhydrite was detected visually and via XRD at this site at $57 \mathrm{mbsf}$ and deeper. $\mathrm{Mg}$ is low, ranging from 3 to $12 \mathrm{mM}$. $\mathrm{K}$ reaches 70 $\mathrm{mM}$ at the high end of concentrations seen in hightemperature fluids from this region (Sakai et al., 1990; Kawagucci et al., 2011; Suzuki et al., 2008). Si is also high, as is methane, which reaches $340 \mathrm{mM}$ (Fig. F23). 


\section{Minor and trace elements}

The minor cations $\mathrm{B}$ and $\mathrm{Li}$, to first order, mimic $\mathrm{K}$ (i.e., compare Fig. F24 with Fig. F19), consistent with the influence of high-temperature solutions at this site. Likewise, Sr mimics Ca. Ba exhibits a maximum (Fig. F25) within the zone of sulfate depletion, consistent with possible dissolution of dispersed barite within the sediment. Dissolved Mn (Fig. F25) increases abruptly at $\sim 10$ mbsf, roughly coincident with several other major and trace elements. A second, more pronounced Mn peak lies with the zone of volatile enrichment in Hole C0014G and somewhat deeper but near the boundary of that enrichment in Hole C0014B (Fig. F22). After decreasing with depth to $\sim 40 \mathrm{mbsf}, \mathrm{Mn}$ increases again, gradually, toward the base of the profile in Hole C0014G. Iron is quite low through much of the sediment column with some increase near the base of the profile (Fig. F25).

\section{Alkalinity, phosphate, and silicon}

Although high-temperature, basalt-hosted midocean-ridge hydrothermal systems tend to be a sink for alkalinity (Mottl, 1983; Wheat and Mottl, 2004), systems where sediment is present can have elevated alkalinities (e.g., Wheat and Mottl, 2000). Within the upper sediment column at Site C0014, high alkalinities (Fig. F21) are driven by relatively high rates of sulfate reduction of organic matter, which is approximated by

$$
\mathrm{SO}_{4}{ }^{2-}+2 \mathrm{CH}_{2} \mathrm{O}=\mathrm{H}_{2} \mathrm{~S}+2 \mathrm{HCO}_{3}{ }^{-} .
$$

With increasing depth, alkalinity at this site becomes quite variable, but there appears to be a deep alkalinity minimum at the base of Hole C0014G that also seems to coincide with a minimum in $\mathrm{Mg}$. This coincidence may result from addition of acidity during Mg removal (Mottl, 1983). Phosphate, like alkalinity and sulfate, may have a significant imprint of organic matter diagenesis or other microbial processes within the upper sediment column. Silicon profiles are generally consistent among the different holes, showing increasing concentrations with depth (Fig. F21). High concentrations of silicon are not unusual for high-temperature systems, which are typically saturated with quartz at temperatures above $130^{\circ}-$ $180^{\circ} \mathrm{C}$ (Mottl, 1983). Si concentrations at depths $>90$ mbsf ( $\sim 4.5 \mathrm{mM})$ are consistent with equilibrium with quartz (Von Damm et al., 1991) at these temperatures, which exceed $210^{\circ} \mathrm{C}$ below 50 mbsf. However, $\mathrm{Si}$ concentrations at Site C0014 are generally lower than values for hot springs previously published for this region (Sakai et al., 1990; Kawagucci et al., 2011; Suzuki et al., 2008), which can exceed $12 \mathrm{mM}$ and presumably reflect higher temperatures.

\section{Headspace gas}

Methane was detected in all samples at Site C0014 (Fig. F23). Similar trends were found for both safety gas (Table T9) and science gas (Table T10) samples. As at other sites, heated safety gas samples yielded higher estimates of pore water methane.

In Hole C0014B, spikes in methane were found in the science gas samples, which measure methane with higher depth resolution than the safety gas samples. These spikes correlate with intervals of low sulfate in the pore waters. In the other holes, methane generally remains low within the uppermost $\sim 50$ mbsf and then increases with depth. Gases sampled from void spaces in these holes at 10-25 mbsf, however, indicate that the gas content measured in headspace samples is a significant underestimate for this interval. The methane to ethane ratio in safety gas samples is high (Fig. F23), with multiple horizons throughout the sediment column showing no detectable ethane. Void gas was sampled at eight depths between 12 and 24 mbsf. This gas has an average methane to ethane ratio of $7508 \pm 474(1 \sigma)$, with a maximum of 8115 at 21 mbsf. Methane content of these void gases is estimated to be as high as $44.6 \%$ by volume at 24 mbsf.

Methane concentrations were observed to be both variable (Hole C0014B) and low (Hole C0014G) within the upper part of the sediment column, indicating zones of anaerobic methanotrophy at sulfatemethane transitions. The observed high methane to ethane ratios suggest that the methane is biogenic, with production certainly occurring in the zone where void gas was observed. Higher temperatures measured at greater depth (e.g., $>120^{\circ} \mathrm{C}$ at $38 \mathrm{mbsf}$ ) would seem to preclude in situ methanogenesis for the deeper peaks. Biogenic methane could be migrating downward from the biologically active zone, or the observed methane at depth (Hole C0014G) could be hydrothermal in origin.

Hydrogen concentrations (Table T11; Fig. F26) are low at depths above $~ 40$ mbsf; at greater depths, concentrations are high but variable. Cores taken with aluminum core liners show higher hydrogen than those taken with plastic core liners, making interpretation of these data difficult. We also found that headspace samples with high hydrogen yielded an even higher concentration when analyzed again 2 days later.

\section{Sediment carbon, nitrogen, and sulfur composition}

Calcium carbonate $\left(\mathrm{CaCO}_{3}\right)$ content calculated from inorganic carbon concentration ranges from 33.1 $\mathrm{wt} \%$ to below the detection limit of $0.001 \mathrm{wt} \%$ and 
is generally $<0.1$ wt\% (Table T12; Fig. F27). High $\mathrm{CaCO}_{3}$ contents $(>1 \mathrm{wt} \%)$ were observed at depths shallower than $10 \mathrm{mbsf}$, where the sediment is hemipelagic silty clay or clay and the carbonate is probably biogenic, and at $\sim 30 \mathrm{mbsf}$, where the sediment is hydrothermally altered and contains detrital sulfide and the carbonate may be authigenic. The highest concentration (33.1 $\mathrm{wt} \%)$ was measured in a vein from 25 mbsf in Hole C0014G where there is some dolomite present. At depths below $30 \mathrm{mbsf}$, the $\mathrm{CaCO}_{3}$ content is $<0.1 \mathrm{wt} \%$.

Total organic carbon (TOC) ranges from $1.20 \mathrm{wt} \%$ to below the detection limit of $0.001 \mathrm{wt} \%$ (Fig. F28). TOC is high near the seafloor and decreases with depth to concentrations $<0.1 \mathrm{wt} \%$ below $30 \mathrm{mbsf}$, reflecting changes in lithology. Sediments from 0 to 20 mbsf are hemipelagic mud and pumice that are hydrothermally altered and contain detrital hydrothermal sulfide at 20-30 mbsf. Below 30 mbsf there are silicified volcanic sediments. Total nitrogen (TN) ranges from $0.6 \mathrm{wt} \%$ to below the detection limit of $0.001 \mathrm{wt} \%$. Like TOC, TN is high near the seafloor and decreases with depth to $\sim 30$ mbsf. Ratios of TOC to $\mathrm{TN}(\mathrm{C} / \mathrm{N})$ within the uppermost $30 \mathrm{mbsf}$ are generally larger than the Redfield ratio of 6.6 , indicating an organic origin for these elements. Some values are smaller than the Redfield ratio, however, suggesting that some portion of nitrogen may be inorganic in origin. Below $30 \mathrm{mbsf}, \mathrm{TN}$ is generally higher than TOC, indicating that most nitrogen is inorganic.

The total sulfur (TS) content is generally high, ranging from 0.66 to $15.7 \mathrm{wt} \%$. The high content reflects the significant amount of sulfide and sulfate minerals that are present. TS increases with depth to a maximum at $\sim 30 \mathrm{mbsf}$, where hydrothermally altered sediment is abundant (see "Lithostratigraphy"). The highest TS was measured in Hole C0014D within a layer of coarse sphalerite and pyrite.

\section{Microbiology}

\section{Total prokaryotic cell counts}

The abundance of microbial cells in the subseafloor at Site C0014 was evaluated by fluorescent microscopy using SYBR Green I as a fluorochrome dye. Commonly among the holes at Site C0014, the highest cell abundances were found in sediments near the seafloor. The maximal abundances in Holes C0014B and C0014G are $1.8 \times 10^{7}$ and $3.3 \times 10^{7}$ cells $/ \mathrm{mL}$ sediment (at 0.33 and $0.27 \mathrm{mbsf}$ ), respectively, whereas that in Hole C0014D is $4.7 \times 10^{8}$ cells/mL sediment (at $0.23 \mathrm{mbsf}$ ) (Fig. F29; Table T13). Cell numbers generally decrease with increas- ing depth, although there are secondary peaks at 14.3, 8.6, and $22.1 \mathrm{mbsf}$ in Holes C0014B, C0014D, and $\mathrm{C} 0014 \mathrm{E}$, respectively. At depths below $17.2 \mathrm{mbsf}$ in Hole C0014B, 11.4 mbsf in Hole C0014D, and 4.1 mbsf in Hole C0014G, microbial cell numbers decrease to below our detection limit of $\sim 1-4 \times 10^{6}$ cells/mL. Maximum cell abundances in Holes C0014B and C0014G are similar to those at Sites C0015 and C0017, but Hole C0014D yielded a significantly higher maximum than any other hole drilled on Expedition 331.

\section{Cultivation of thermophiles}

Growth of Thermococcales (e.g., Thermococcus) at $80^{\circ} \mathrm{C}$ and Aquificales (e.g., Persephonella) and thermophilic Epsilonproteobacteria (e.g., Nitratiruptor) at $55^{\circ} \mathrm{C}$ was examined for all core samples taken at Site C0014. No growth of any thermophilic microorganism tested for was observed.

\section{Cultivation of iron-oxidizing bacteria}

Selected samples from Site C0014 were incubated in artificial seawater (ASW) media A and B for depths from 0.23 to $42.45 \mathrm{mbsf}$ (Table T14). Growth was observed only within the uppermost $1.93 \mathrm{~m}$. It is likely that extreme temperatures at depth at Site C0014 make the habitat inhospitable for mesophilic iron oxidizers, as was also inferred for Site C0013. Of the samples that grew, observed cellular morphologies are similar to what was seen at Site C0015. From Section 331-C0014B-1H-1, rod-shaped cells $\sim 2 \mu \mathrm{m}$ long were observed aggregated on large particles (Fig. F30A, F30B). Figure F30C and F30D shows a sheathlike structure containing two rod-shaped particle-associated cells. Though found only in shallow sediments, these Site C0014 enrichments may prove useful for comparisons with Site C0015 iron oxidizers, both shallow and deep.

\section{Contamination tests}

Fluorescent microspheres were used to test for contamination in all cores from Site C0014 obtained with the HPCS (Table T15). Perfluorocarbon tracer (PFT) was also used as a contamination tracer in all cores from this site (Table T16). Microspheres were not observed in most of the core samples, even in exterior parts of the cores. As at Site C0013, the plastic microspheres may have melted at greater depths, as temperature exceeded $120^{\circ} \mathrm{C}$ at $38 \mathrm{mbsf}$ and deeper in Hole C0014G.

PFT was not detected from the interior of more than half of the core samples obtained by the HPCS. Conversely, it was detected in the interiors of most samples taken by the ESCS or EPSC, although at concen- 
trations much lower than in the drilling mud (Table T16). PFT was also detected in cores exposed to high temperatures. Although PFT is a highly volatile chemical, our results suggest that it may be used as a tracer for contamination even at high temperatures.

Relatively high numbers of microspheres and high concentrations of PFT were observed in samples containing pumice, for example at $6.67 \mathrm{mbsf}$ in Hole C0014D and at 7.84 mbsf in Hole C0014G. PFT concentrations in such samples, however, were at least an order of magnitude lower than concentrations in the drilling fluid. Permeable layers are often highly disturbed during recovery, making the external contamination unavoidable.

\section{Conclusion}

Site C0014 is located at a Calyptogena colony site in the Iheya North hydrothermal field. Also observed at this site are patches of black-colored sediments and white bacterial or sulfur mats. Calyptogena clams require $\mathrm{H}_{2} \mathrm{~S}$ as an energy source (Cavanaugh et al., 2006). Consequently, the transition from a psychrophilic microbial community at and near the seafloor that is not obviously dependent on hydrothermal input to a deeper one that is thermophilic and highly dependent on hydrothermal input was the major focus for microbiology at Site C0014. Unfortunately, our shipboard cell counts and cultivation experiments did not detect a deeper (hyper)thermophilic community, even though there is a potentially habitable zone at $<120^{\circ} \mathrm{C}$ that extends as deep as $38 \mathrm{mbsf}$, over which sulfate decreases to nearly zero (by 12-31 mbsf in all holes) and methane is generated biogenically. Growth of mesophilic FeOB was detected within the uppermost $2 \mathrm{~m}$ only. It appears that functionally active, metabolically diverse microbial communities may be limited to the shallower zones of the subseafloor at Site C0014. As was the case at Site C0013, it is likely that temperatures over the key depth interval of $\sim 15-38$ mbsf exceeded the limits for life recently enough that microbial communities are largely absent. This conclusion is consistent with the presence of illite at $\sim 10-25 \mathrm{mbsf}$ and $\mathrm{Mg}$ chlorite at 25 mbsf to the maximum depth drilled at Site C0014.

\section{Physical properties}

Physical property measurements were made at Site C0014 to nondestructively characterize lithological units and states of sediment consolidation.

\section{Density and porosity}

Bulk density was determined from both gamma ray attenuation (GRA) measurements on whole cores (with the multisensor core logger for whole-round samples [MSCL-W]) and moisture and density (MAD) measurements on discrete samples (see "Physical properties" in Expedition 331 Scientists, 2011b). A total of 208 discrete samples were analyzed for MAD $(6,66,6,17,18,5$, and 90 samples from Holes C0014A, C0014B, C0014C, C0014D, C0014E, C0014F, and C0014G, respectively). Wet bulk density is roughly constant with depth, as determined by both MAD and GRA, although the latter values are generally lower than the former and exhibit more scatter (Fig. F31). This is expected of the GRA-derived density, as GRA measured by the MSCL-W is very sensitive to incompletely filled core liners and the presence of voids and cracks.

Bulk density values are very similar for all holes at this site (Table T17). Average bulk density in Hole C0014G is $\sim 1.7 \mathrm{~g} / \mathrm{cm}^{3}$; bulk density lies between 1.2 and $1.6 \mathrm{~g} / \mathrm{cm}^{3}$ in the uppermost $60 \mathrm{~m}$ of the hole and increases slightly to values between 1.6 and 1.9 $\mathrm{g} / \mathrm{cm}^{3}$ between 60 and 130 mbsf. At 127 mbsf bulk density is $2.7 \mathrm{~g} / \mathrm{cm}^{3}$.

Grain density was calculated from discrete MAD measurements and is also approximately constant with depth $\left(\sim 2.7-3.1 \mathrm{~g} / \mathrm{cm}^{3}\right)$ (Table T17). Lower grain densities $\left(2-2.5 \mathrm{~g} / \mathrm{cm}^{3}\right)$ are present between 5 and 15 mbsf. Higher grain densities $\left(>3.25 \mathrm{~g} / \mathrm{cm}^{3}\right)$ are present in two intervals, from 20 to 50 mbsf and at $\sim 80$ mbsf.

Porosity was calculated from MAD measurements. It is generally quite high $(60 \%-80 \%)$ in the shallower holes (C0014A-C0014F) and in the uppermost 60-80 $\mathrm{m}$ of Hole C0014G (Fig. F32). Porosity decreases slightly with depth between 80 and 120 mbsf in Hole C0014G to values between $40 \%$ and $60 \%$. Porosity decreases sharply at 127 mbsf to $0.13 \%$, consistent with the increase in bulk density.

Density and porosity results from the seven holes at Site C0014 reveal a pattern consistent with the presence of thick water-rich sediments. Only below 127 mbsf is there any indication that sediments have become significantly more lithified. There are no obvious lithological units that can be distinguished based on the density and porosity data.

\section{Electrical resistivity (formation factor)}

Formation factor is a measure of the connected pore space within sediments and is used to calculate the bulk sediment diffusion coefficient. Electrical impedance measurements were made at 227 depths (10, $71,8,20,20,5$, and 93 measurements in Holes C0014A, C0014B, C0014C, C0014D, C0014E, C0014F, and C0014G, respectively). Formation factors (a resistivity ratio and thus a unitless parameter) 
calculated for Hole C0014G range from $~ 2$ to 12 and increase with depth (Fig. F33). The average value for the formation factor at this site was $4.36 \pm 1.5$ (Table T17). Values for formation factor and the rate of increase in formation factor with depth are similar for all holes at this site.

\section{Discrete $P$-wave velocity and anisotropy measurements}

$P$-wave velocity and relative anisotropy were measured on samples indurated enough to cut sample polyhedrons, which was rarely the case. $P$-wave velocity on discrete samples from $\sim 127 \mathrm{mbsf}$ in Hole C0014G range from 3000 to $4000 \mathrm{~m} / \mathrm{s}$ (data not shown).

\section{Thermal conductivity}

Thermal conductivity was measured on whole-round cores. A total of 221 measurements were made (13, 95, 3, 15, 28, 4, and 63 measurements from Holes C0014A, C0014B, C0014C, C0014D, C0014E, C0014F, and C0014G, respectively). Thermal conductivity in Hole C0014G ranged from a low value of $\sim 0.9 \mathrm{~W} /(\mathrm{m} \cdot \mathrm{K})$ to as high as $\sim 2 \mathrm{~W} /(\mathrm{m} \cdot \mathrm{K})$ (Fig. F34). Average thermal conductivity for all seven holes is $0.88 \pm 0.22 \mathrm{~W} /(\mathrm{m} \cdot \mathrm{K})$. Thermal conductivity increases slightly with depth and is loosely and inversely correlated with porosity. As porosity decreases, thermal conductivity increases as water is forced from void spaces because thermal conductivity of grains is greater than that of water. Narrow zones of higher thermal conductivity are also roughly coincident with peaks in the MSCL-W $P$-wave velocity (Fig. F35), where higher velocities should also correspond to regions with less porous, more dense material (data not shown).

\section{In situ temperature}

In situ temperature was measured using the advanced piston corer temperature tool (APCT3) (four measurements at 4.2-16 mbsf) and thermoseal strips (three measurements at 38, 47, and $50 \mathrm{mbsf}$ ) (Table T18; Fig. F36). For the APCT3, the temperature-time series was recorded at $1 \mathrm{~s}$ intervals. The APCT3 was stopped at the mudline for as long as $10 \mathrm{~min}$ prior to penetration, and the average of four measurements of apparent bottom water temperature is $4.51^{\circ} \pm 0.17^{\circ} \mathrm{C}(1 \sigma)$. Temperature-time series for each of the four measurement intervals are shown in Figure F37. Temperature records show significant frictional heating as the coring shoe penetrated the sediment (time $=0$ ), followed by subsequent temperature decay toward the in situ value. For most of the measurements, the probe was kept in the sediment for $>5 \mathrm{~min}$, allowing a more accurate extrapolation to the equilibrium formation temperature based on a 1/time approximation (Table T18). All measurements (except perhaps for the one collected from Core 331-C0014D-2H) appear to be reliable, exhibiting good penetration heating and smooth initial decay curves. Equilibrium fits to the temperature-time series are also good and yield the formation temperatures that are plotted versus depth in Figure F36. The temperature recorded during collection of Core 331-C0014D-2H at $16 \mathrm{mbsf}$ was very slightly higher $\left(55.1^{\circ} \mathrm{C}\right)$ than the maximum calibration temperature for the APCT3 probe $\left(55^{\circ} \mathrm{C}\right)$. Two of the three temperature measurements with thermoseal strips exceeded the range of beads on the strip used and are thus minimum temperature estimates ( 37.6 and $50.2 \mathrm{mbsf}$ ). For the third measurement (46.9 mbsf), the beads for $125^{\circ}, 130^{\circ}$, and $140^{\circ} \mathrm{C}$ were blackened but those for $150^{\circ}$ and $160^{\circ} \mathrm{C}$ were not, indicating that the temperature reached or exceeded $140^{\circ} \mathrm{C}$ but did not reach $150^{\circ} \mathrm{C}$. We report this value as $145^{\circ} \pm 5^{\circ} \mathrm{C}$. We have not calculated heat flow at this time because of the strongly nonlinear increase in temperature with depth.

\section{MSCL-I and MSCL-C imaging}

MSCL-derived core images and color analyses are presented in the visual core descriptions (VCDs).

\section{MSCL-W derived electrical resistivity}

MSCL-W-based resistivity data are generally low $(<10 \Omega \mathrm{m})$ at depths shallower than 25 mbsf. There are some zones that exhibit increased resistivity where densities are high and porosities are low: $>20$ $\Omega \mathrm{m}$ at $\sim 18 \mathrm{mbsf}$ in Hole C0014D, $>40 \Omega \mathrm{m}$ at $\sim 30$ mbsf in Hole C0014E, and as high as $300 \Omega \mathrm{m}$ at $\sim 25$ mbsf in Hole C0014B. However, there is no obvious relationship with discrete measurements of formation factor (Fig. F38 versus Fig. F33).

\section{References}

Árkai, P., 2002. Phyllosilicates in very low-grade metamorphism: transformation to micas. In Mottana, A., Sassi, F.P., Thompson, J.B., Jr., and Guggenheim, S. (Eds.), Micas: Crystal Chemistry and Metamorphic Petrology. Rev. Mineral. Geochem., 46(1):463-478. doi:10.2138/ rmg.2002.46.11

Bandy, O.L., 1960. The geologic significance of coiling ratios in the foraminifer Globigerina pachyderma (Ehrenberg). J. Paleontol., 34(4):671-681. http://jpaleontol.geoscienceworld.org/cgi/content/abstract/34/4/ 671

Bischoff, J.L., and Seyfried, W.E., 1978. Hydrothermal chemistry of seawater from $25^{\circ} \mathrm{C}$ to $350^{\circ} \mathrm{C}$. Am. J. Sci., 278(6):838-860. doi:10.2475/ajs.278.6.838 
Browne, P.R.L., 1978. Hydrothermal alteration in active geothermal fields. Annu. Rev. Earth Planet. Sci., 6:229248. doi:10.1146/annurev.ea.06.050178.001305

Cavanaugh, C., McKiness, Z., Newton, I., and Stewart, F., 2006. Marine chemosynthetic symbioses. Prokaryotes, 1:475-507. doi:10.1007/0-387-30741-9_18

Chang, Y.-P., Wang, W.-L., Yokoyama, Y., Matsuzaki, H., Kawahata, H., and Chen, M.-T., 2008. Millennial-scale planktic foraminifer faunal variability in the East China Sea during the past 40,000 years (IMAGES MD012404 from the Okinawa Trough). Terr. Atmos. Oceanic Sci., 19(4):389-401. doi:10.3319/

TAO.2008.19.4.389(IMAGES)

Dou, Y., Yang, S., Liu, Z., Clift, P.D., Yu, H., Berne, S., and Shi, X., 2010. Clay mineral evolution in the central Okinawa Trough since $28 \mathrm{ka}$ : implications for sediment provenance and paleoenvironmental change. Palaeogeogr., Palaeoclimatol., Palaeoecol., 288(1-4):108-117. doi:10.1016/j.palaeo.2010.01.040

Ericson, D.B., 1959. Coiling direction of Globigerina pachyderma as a climatic index. Science, 130(3369):219-220. doi:10.1126/science.130.3369.219

Expedition 331 Scientists, 2011a. Expedition 331 summary. In Takai, K., Mottl, M.J., Nielsen, S.H., and the Expedition 331 Scientists, Proc. IODP, 331: Tokyo (Integrated Ocean Drilling Program Management International, Inc.). doi:10.2204/iodp.proc.331.101.2011

Expedition 331 Scientists, 2011b. Methods. In Takai, K., Mottl, M.J., Nielsen, S.H., and the Expedition 331 Scientists, Proc. IODP, 331: Tokyo (Integrated Ocean Drilling Program Management International, Inc.). doi:10.2204/iodp.proc.331.102.2011

Expedition 331 Scientists, 2011c. Site C0013. In Takai, K., Mottl, M.J., Nielsen, S.H., and the Expedition 331 Scientists, Proc. IODP, 331: Tokyo (Integrated Ocean Drilling Program Management International, Inc.). doi:10.2204/iodp.proc.331.103.2011

Fiske, R.S., Naka, J., Iizasa, K., Yuasa, M., and Klaus, A., 2001. Submarine silicic caldera at the front of the IzuBonin arc, Japan: voluminous seafloor eruptions of rhyolite pumice. Geol. Soc. Am. Bull., 113(7):813-824. doi:10.1130/00167606(2001)113<0813:SSCATF >2.0.CO;2

Folk, R.L., and Ward, W.C., 1957. Brazos River bar [Texas]: a study in the significance of grain size parameters. $J$. Sediment. Res., 27(1):3-26. http://jsedres.sepmonline.org/cgi/content/abstract/27/1/3

Gieskes, J.M., Simoneit, B.R.T., Shanks, W.C., III, Goodfellow, W.D., James, R.H., Baker, P.A., and Ishibashi, J., 2002. Geochemistry of fluid phases and sediments: relevance to hydrothermal circulation in Middle Valley, ODP Legs 139 and 169. Appl. Geochem., 17(11):13811399. doi:10.1016/S0883-2927(02)00108-7

Kato, Y., 1987. Woody pumice generated with submarine eruption. Chishitsugaku Zasshi, 93:11-20.

Kawagucci, S., Chiba, H., Ishibashi, J., Yamanaka, T., Toki, T., Muramatsu, Y., Ueno, Y., Makabe, A., Inoue, K., Yoshida, N., Nakagawa, S., Nunoura, T., Takai, K., Takahata, N., Sano, Y., Narita, T., Teranishi, G., Obata, H., and Gamo, T., 2011. Hydrothermal fluid geochemistry at the Iheya north field in the mid-Okinawa Trough: implication for origin of methane in subseafloor fluid circulation systems. Geochem. J., 45(2):109-124. http:// www.terrapub.co.jp/journals/GJ/abstract/4502/ 45020109.html

Kohn, M.J., Riciputi, L.R., Stakes, D., and Orange, D.L., 1998. Sulfur isotope variability in biogenic pyrite: reflections of heterogeneous bacterial colonization? Am. Mineral., 83(11-12):1454-1468. http://www.minsocam.org/msa/ammin/TOC/Articles_Free/1998/ Kohn_p1454-1468_98.pdf

Marumo, K., and Hattori, K.H., 1999. Seafloor hydrothermal clay alteration at Jade in the back-arc Okinawa Trough: mineralogy, geochemistry, and isotope characteristics. Geochim. Cosmochim. Acta, 63(18):2785-2804. doi:10.1016/S0016-7037(99)00158-1

Mottl, M.J., 1983. Metabasalts, axial hot springs, and the structure of hydrothermal systems at mid-ocean ridges. Geol. Soc. Am. Bull., 94(2):161-180. doi:10.1130/ 0016-7606(1983)94<161:MAHSAT>2.0.CO;2

Odin, G.S. (Ed.), 1988. Green Marine Clays: Amsterdam (Elsevier).

Raffi, I., Backman, J., Fornaciari, E., Pälike, H., Rio, D., Lourens, L., and Hilgen, F., 2006. A review of calcareous nannofossil astrobiochronology encompassing the past 25 million years. Quat. Sci. Rev., 25(23-24):3113-3137. doi:10.1016/j.quascirev.2006.07.007

Saidova, K.M., 2007. Benthic foraminiferal assemblages of the South China Sea. Oceanology, 47(5):653-659. doi:10.1134/S0001437007050074

Sakai, H., Gamo, T., Kim, E.-S., Tsutsumi, M., Tanaka, T., Ishibashi, J., Wakita, H., Yamano, M., and Oomori, T., 1990. Venting of carbon dioxide-rich fluid and hydrate formation in mid-Okinawa Trough backarc basin. Science, 248(4959):1093-1096. doi:10.1126/science.248.4959.1093

Seyfried, W.E., Jr., Ding, K., Berndt, M.E., and Chen, X., 1999. Experimental and theoretical controls on the composition of mid-ocean ridge hydrothermal fluids. Rev. Econ. Geol., 8:181-200.

Srodon, J., and Eberl, D.D., 1984. Illite. In Bailey, S.W. (Ed.), Micas. Rev. Mineral., 13(1):495-544.

Suzuki, R., Ishibashi, J.-I., Nakaseama, M., Konno, U., Tsunogai, U., Gena, K., and Chiba, H., 2008. Diverse range of mineralization induced by phase separation of hydrothermal fluid: case study of the Yonaguni Knoll IV hydrothermal field in the Okinawa Trough back-arc basin. Resour. Geol., 58(3):267-288. doi:10.1111/j.17513928.2008.00061.x

Takai, K., Mottl, M.J., and Nielson, S.H.H., 2010. Deep hot biosphere. IODP Sci. Prosp., 331. doi:10.2204/ iodp.sp.331.2010

Von Damm, K.L., Bischoff, J.L., and Rosenbauer, R.J., 1991. Quartz solubility in hydrothermal seawater: an experimental study and equation describing quartz solubility for up to $0.5 \mathrm{M} \mathrm{NaCl}$ solutions. Am. J. Sci., 291:9771007. doi:10.2475/ajs.291.10.977

Wheat, C.G., and Mottl, M.J., 2000. Composition of pore and spring waters from Baby Bare: global implications of geochemical fluxes from a ridge flank hydrothermal system. 
Geochim. Cosmochim. Acta, 64(4):629-642. doi:10.1016/ S0016-7037(99)00347-6

Wheat, C.G., and Mottl, M.J., 2004. Geochemical fluxes through mid-ocean ridge flanks. In Davis, E.E., and Elderfield, H. (Eds.), Hydrogeology of the Oceanic Lithosphere: Cambridge (Cambridge Univ. Press), 627-658.

Winter, A., and Siesser, W.G., 1994. Atlas of living coccolithophores. In Winter, A., and Siesser, W.G. (Eds.), Coccolithophores: Cambridge (Cambridge Univ. Press), 107-159.

Xiang, R., Li, T., Yang, Z., Li, A., Jiang, F., Yan, J., and Cao, Q., 2003. Geological records of marine environmental changes in the southern Okinawa Trough. Chin. Sci. Bull., 48(2):194199. http://www.springerlink.com/content/ 4408tv621836x703/

You, C.-F., Castillo, P.R., Gieskes, J.M., Chan, L.H., and Spivack, A.J., 1996. Trace element behavior in hydrothermal experiments: implications for fluid processes at shallow depth in subduction zones. Earth Planet Sci. Lett., 140(1-4):41-52. doi:10.1016/0012-821X(96)00049-0

You, C.-F., and Gieskes, J.M., 2001. Hydrothermal alteration of hemi-pelagic sediments: experimental evaluation of geochemical processes in shallow subduction zones. Appl. Geochem., 16(9-10):1055-1066. doi:10.1016/ S0883-2927(01)00024-5

Yu, H., Liu, Z., Berné, S., Jia, G., Xiong, Y., Dickens, G.R., Wei, G., Shi, X., Liu, J.P., and Chen, F., 2009. Variations in temperature and salinity of the surface water above the middle Okinawa Trough during the past 37 kyr. Palaeogeogr., Palaeoclimatol., Palaeoecol., 281(1-2):154-164. doi:10.1016/j.palaeo.2009.08.002

Publication: 4 October 2011

MS 331-104 
Figure F1. Bathymetric map, Site C0014.

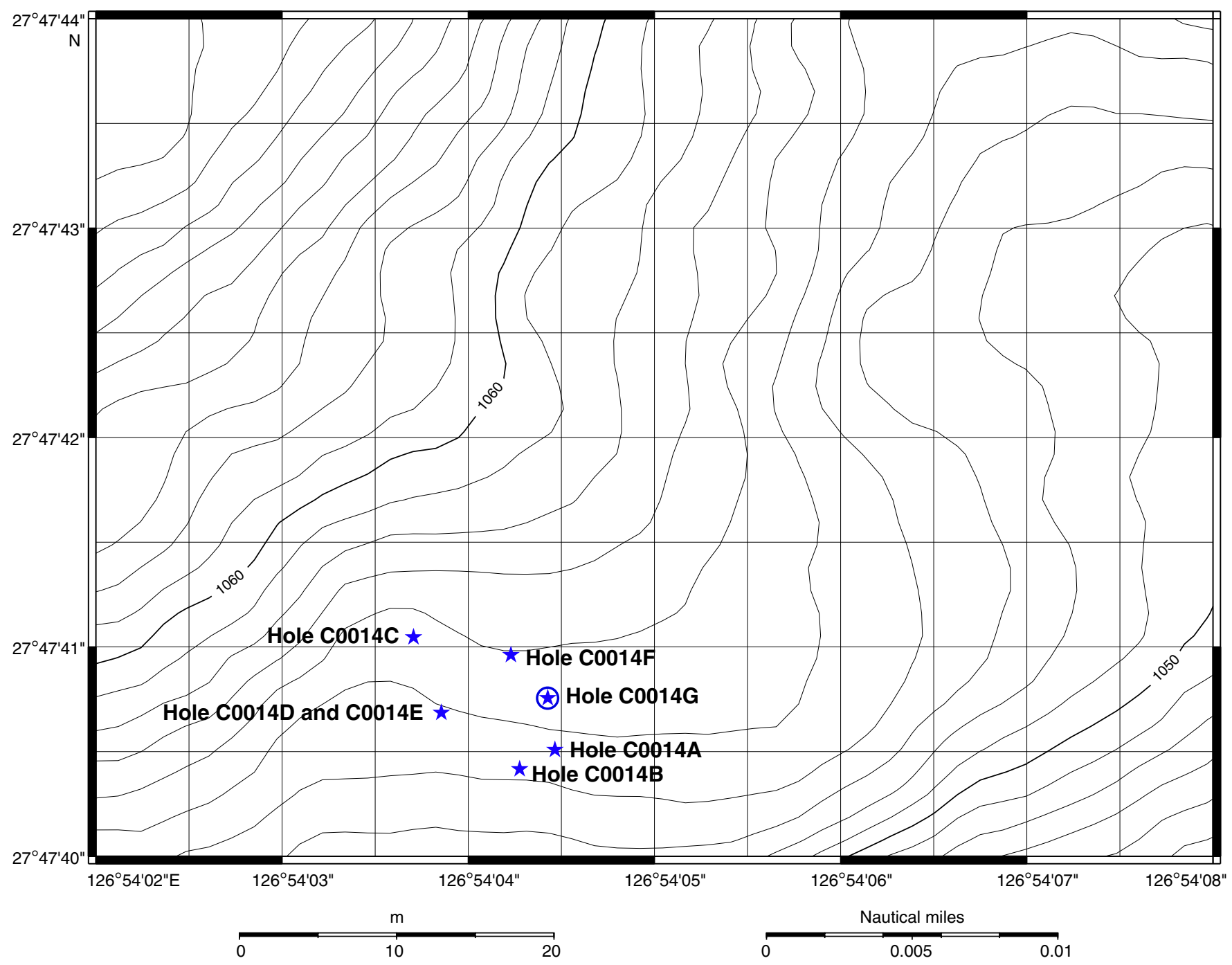


Figure F2. Diagram of stratigraphic units correlated across Site C0014, with accompanying $P$-wave profiles for the two deepest holes: C0014B and C0014G.

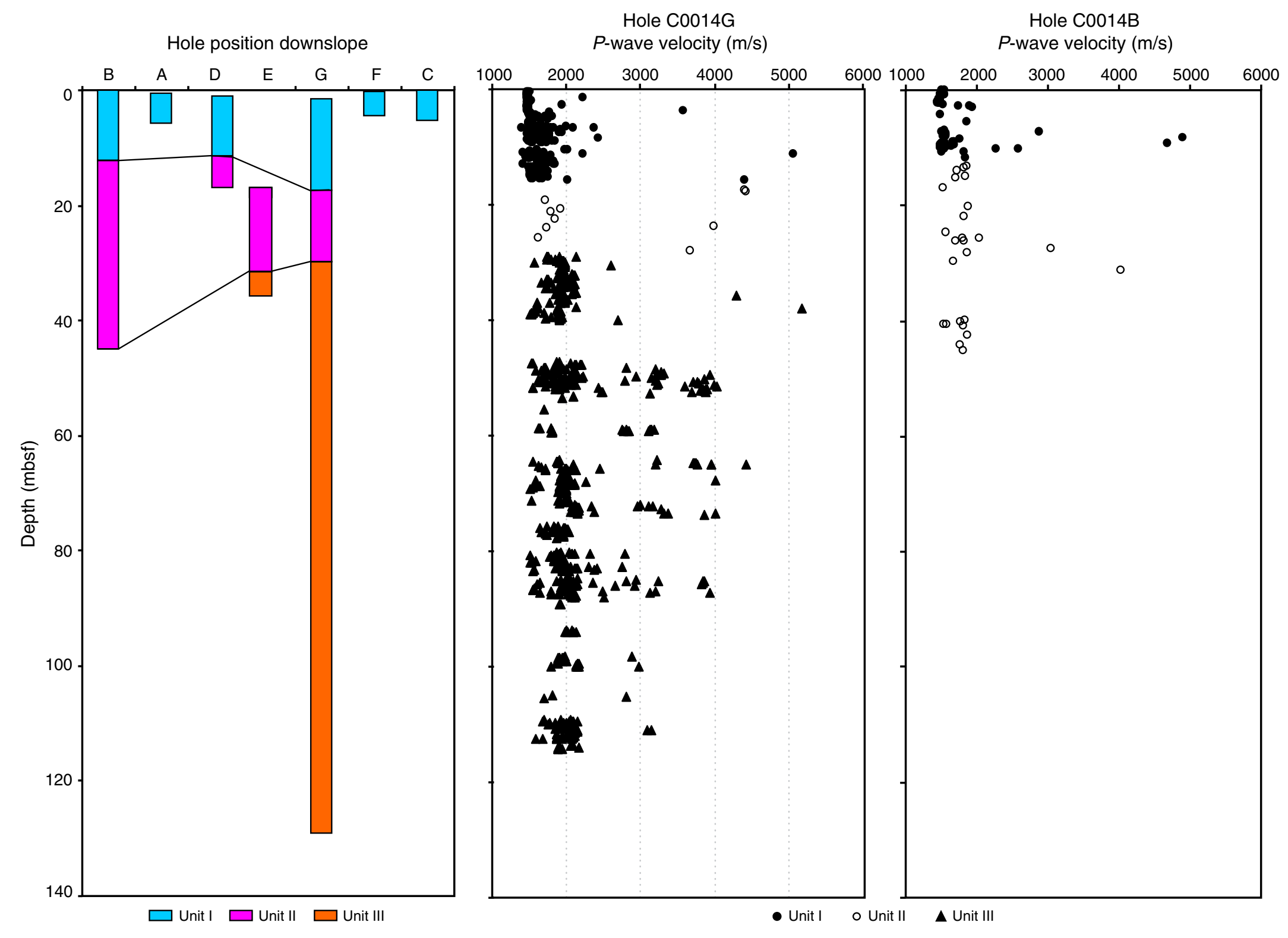


Figure F3. Core photograph of poorly consolidated devitrified pumice clasts exhibiting relict structures (interval 331-C0014G-3H-1, 16-31 cm).

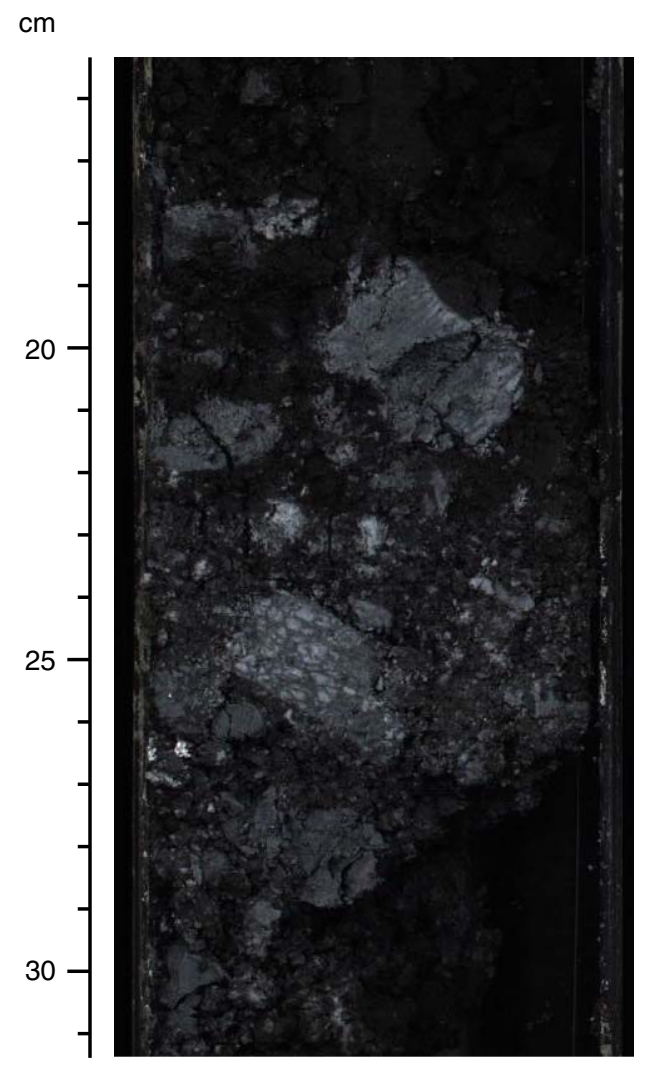


Figure F4. Core photograph of clast and layers of cemented volcaniclastic sediment interbedded in poorly consolidated hydrothermally altered mud (interval 331-C0014G-12H-3, 64-74 cm).

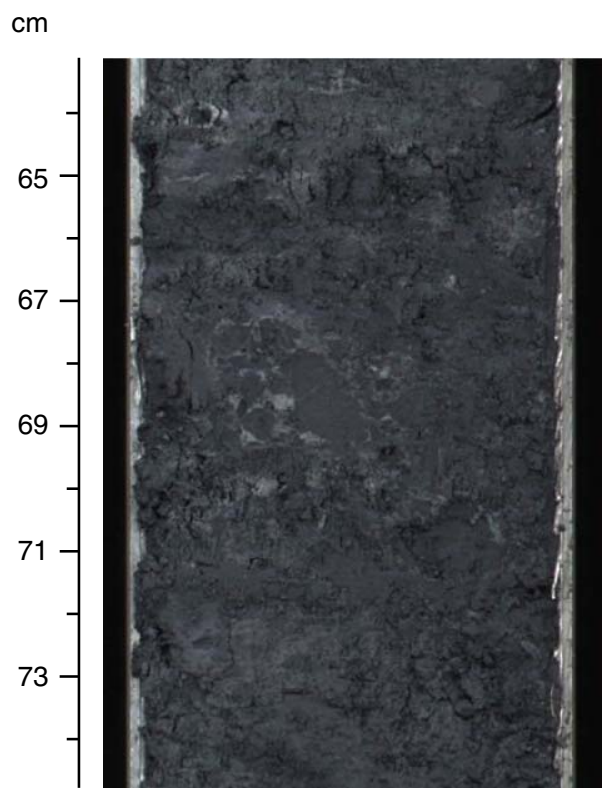


Figure F5. Core photograph of anhydrite vein from Unit III, 65 mbsf (interval 331-C0014G-12H-3, 42-66 cm).

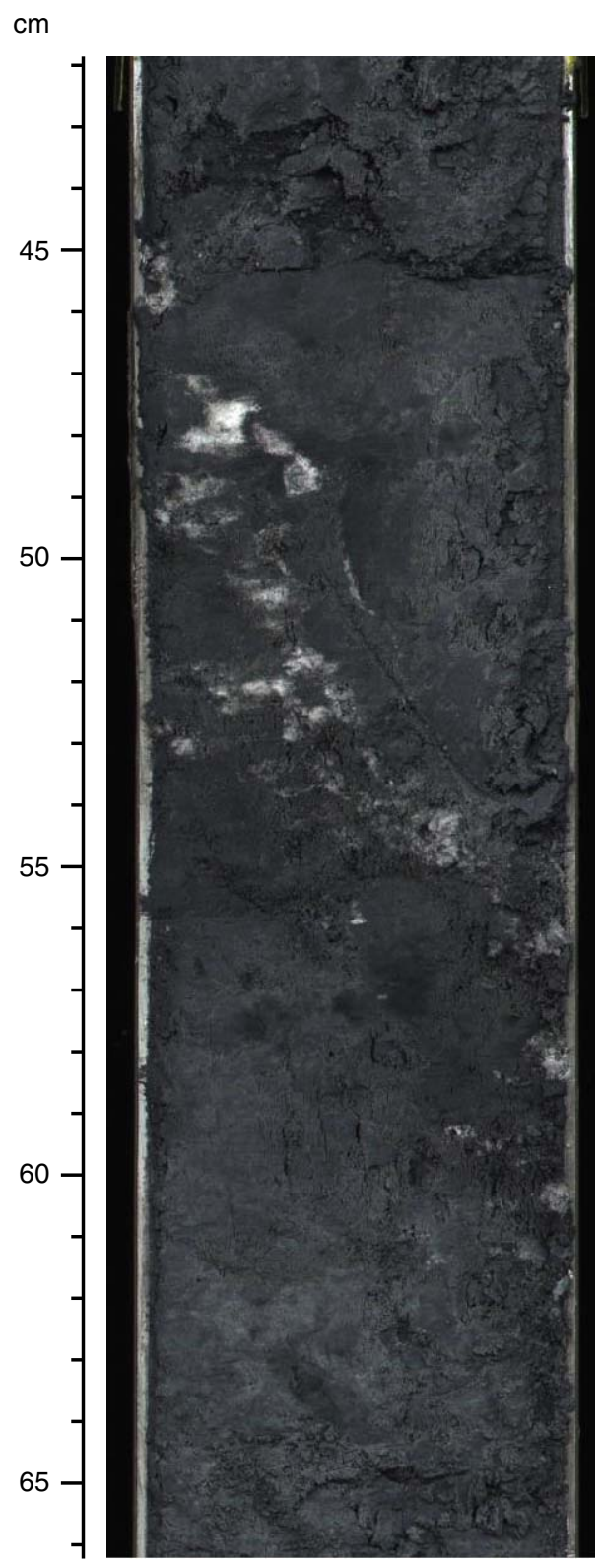



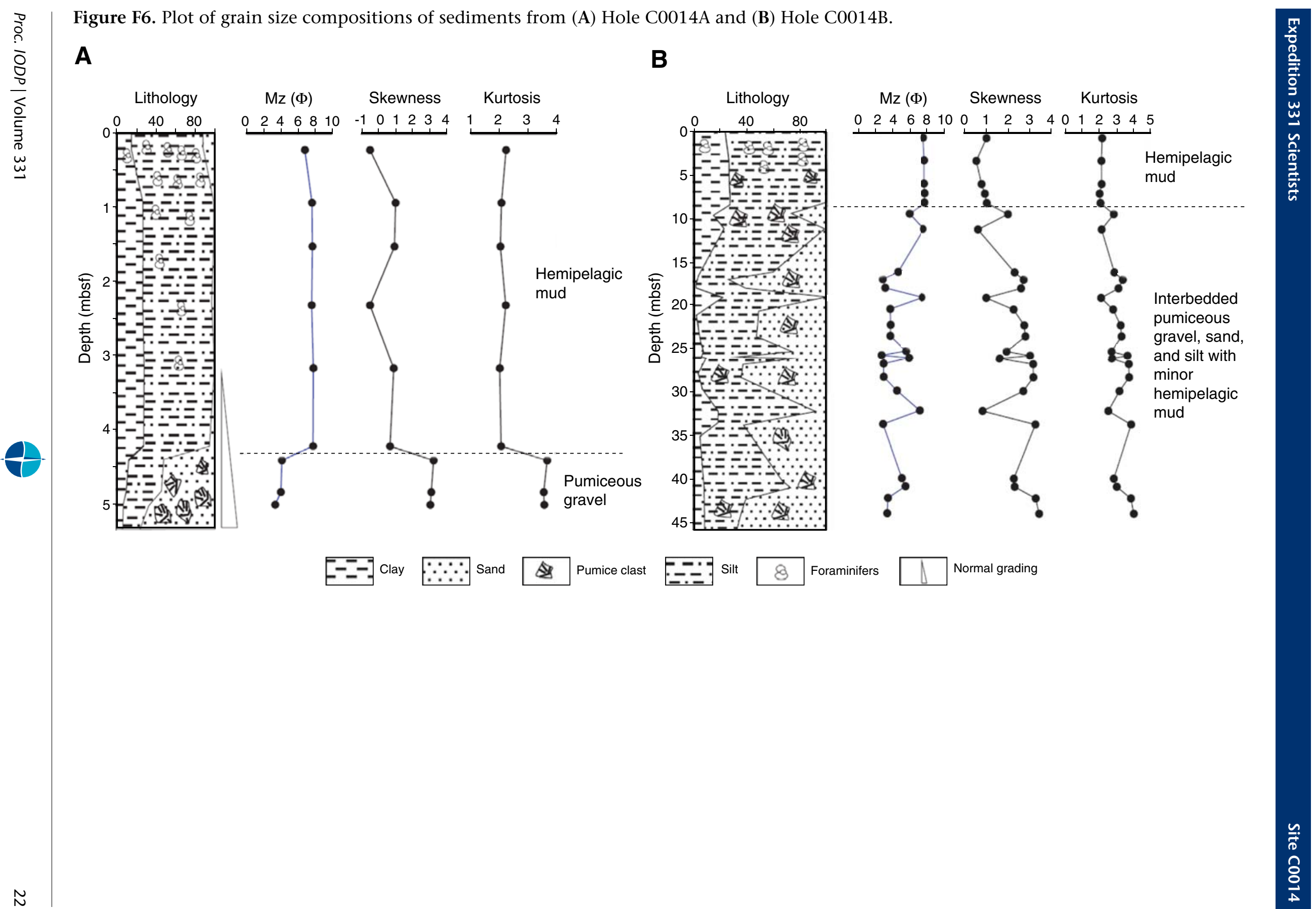
Figure F7. Grain size classification based on Fork and Ward (1957), Holes C0014A, C0014B, and C0013F. s = sand, $\mathrm{cs}=$ clayey sand, $\mathrm{ms}=$ muddy sand, $\mathrm{zs}=$ silty sand, $\mathrm{sc}=$ sandy clay, $\mathrm{sm}=$ sandy mud, $\mathrm{sz}=\mathrm{sandy}$ silt, $\mathrm{c}=$ clay, $\mathrm{m}=$ mud, $\mathrm{z}=$ silt.

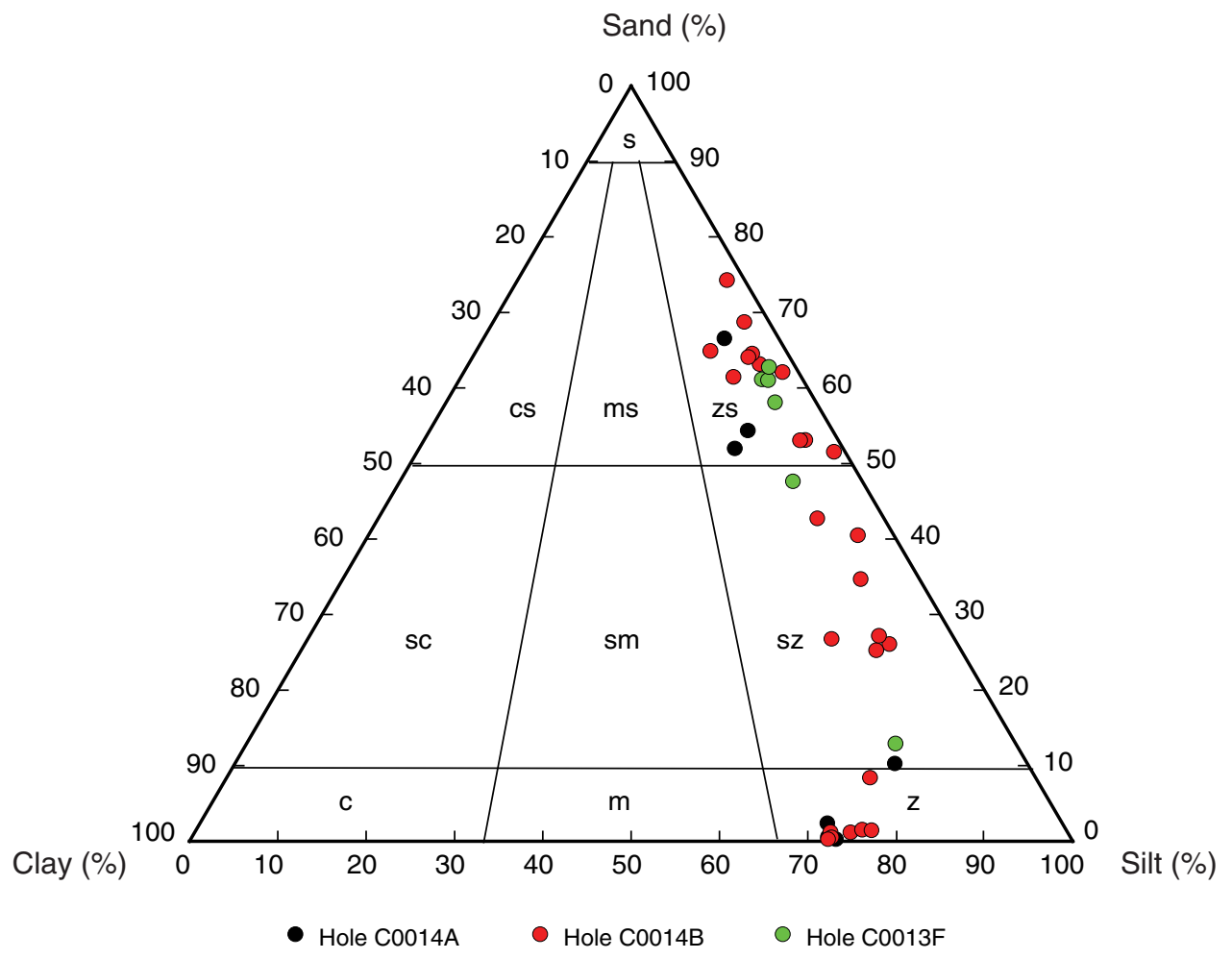


Figure F8. Comparison of grain size patterns among different sediments in Holes C0013F, C0014A, and C0014B.
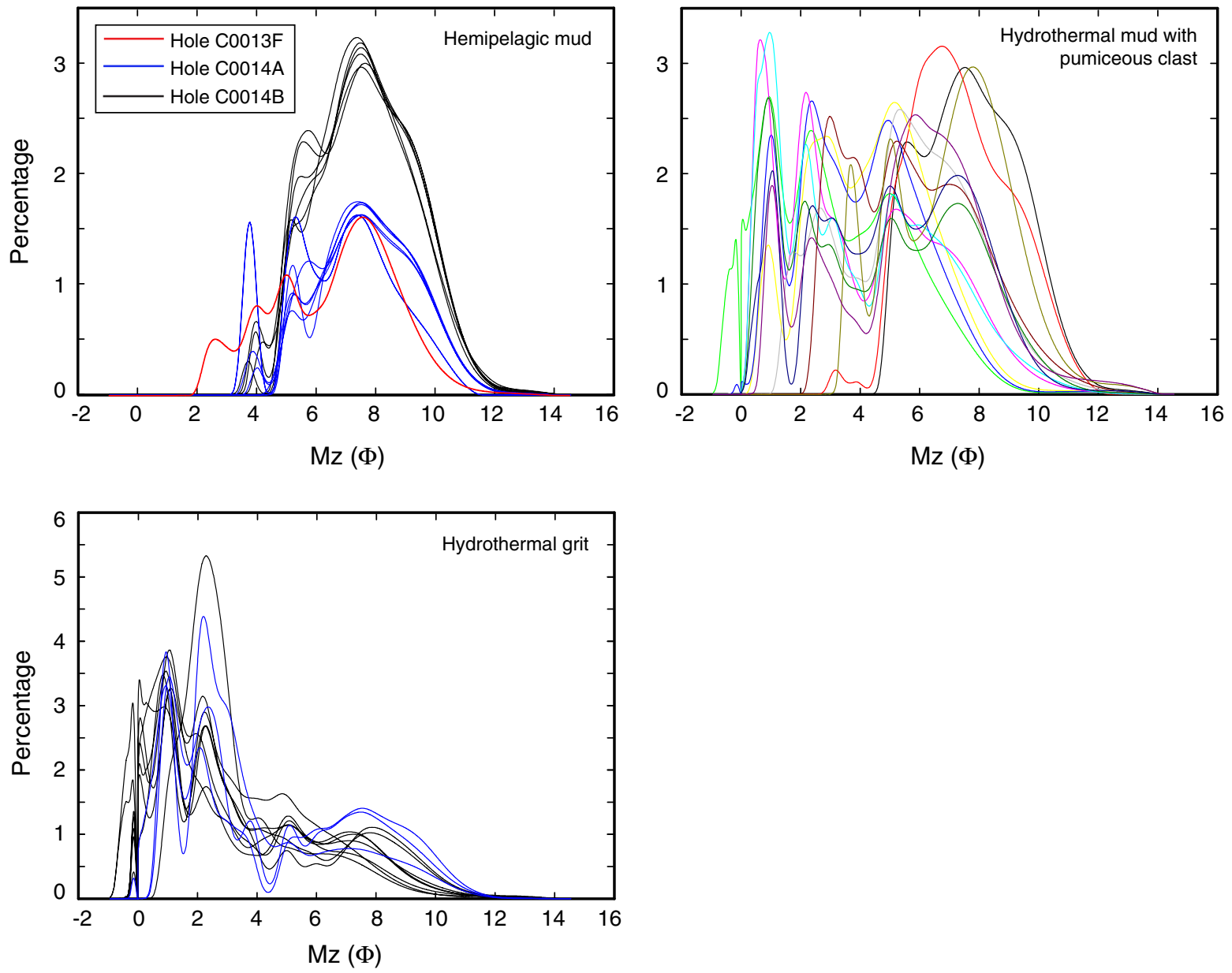
Figure F9. Comparison of grain size patterns for holes drilled during Expedition 331 (Holes C0013F, C0014A, and C0014B) with Core DGKS9604 from the central Okinawa Trough (taken from Yu et al., 2009).
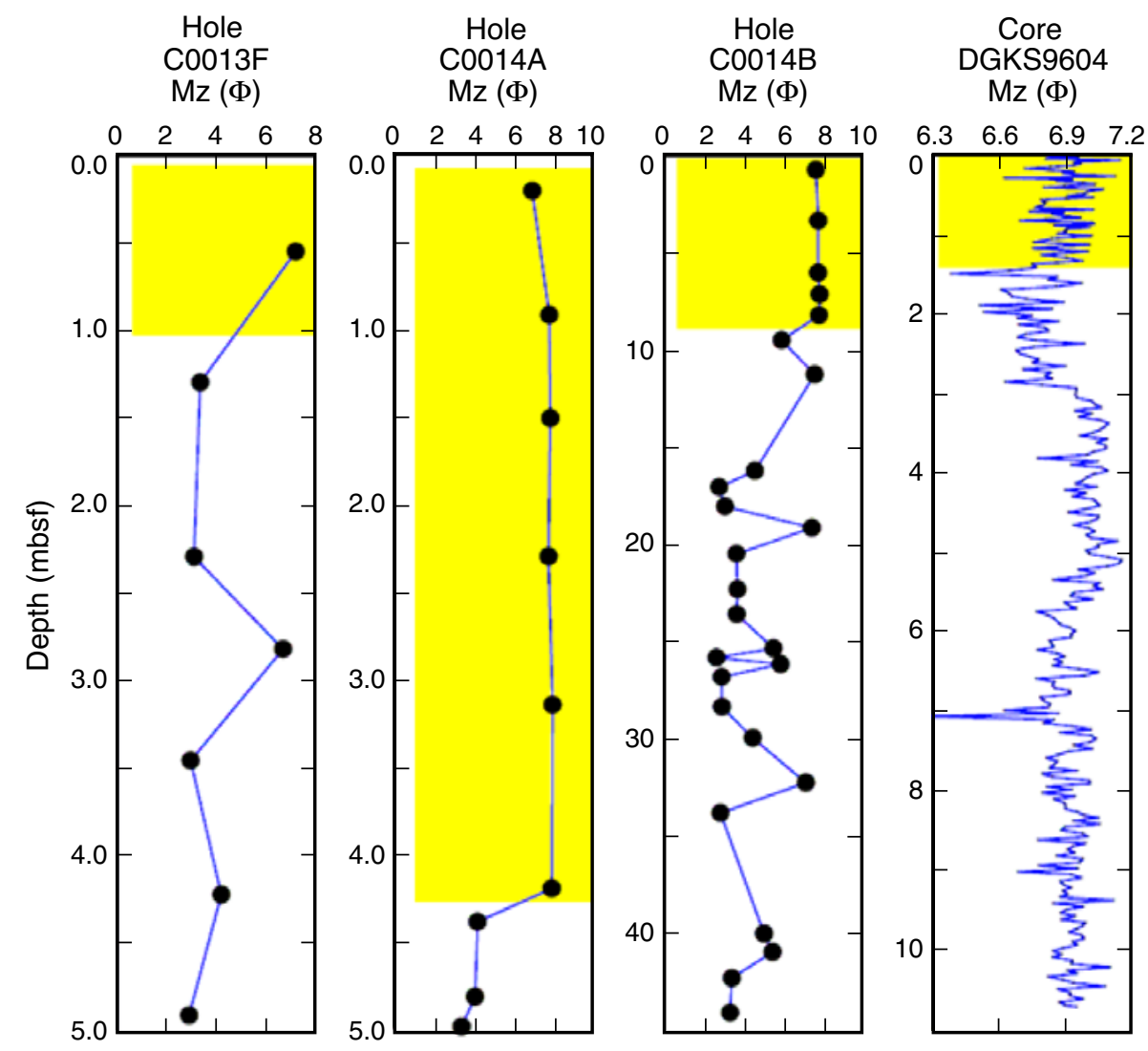
Figure F10. SEM photomicrographs of representative, dominant foraminifers hand-picked from Sample 331C0014A-1H-1, 1-2 cm (0.01 mbsf). A. Globerinoides ruber. B. Globerinoides sacculifer. C. Globorotalia menardi. D. Neogloboquadrina pachyderma (dextral). E. Neogloboquadrina eggeri. F. Neogloboquadrina himiensis. G. Orbulina universa. H. Pulleniatina obiquiloculata.
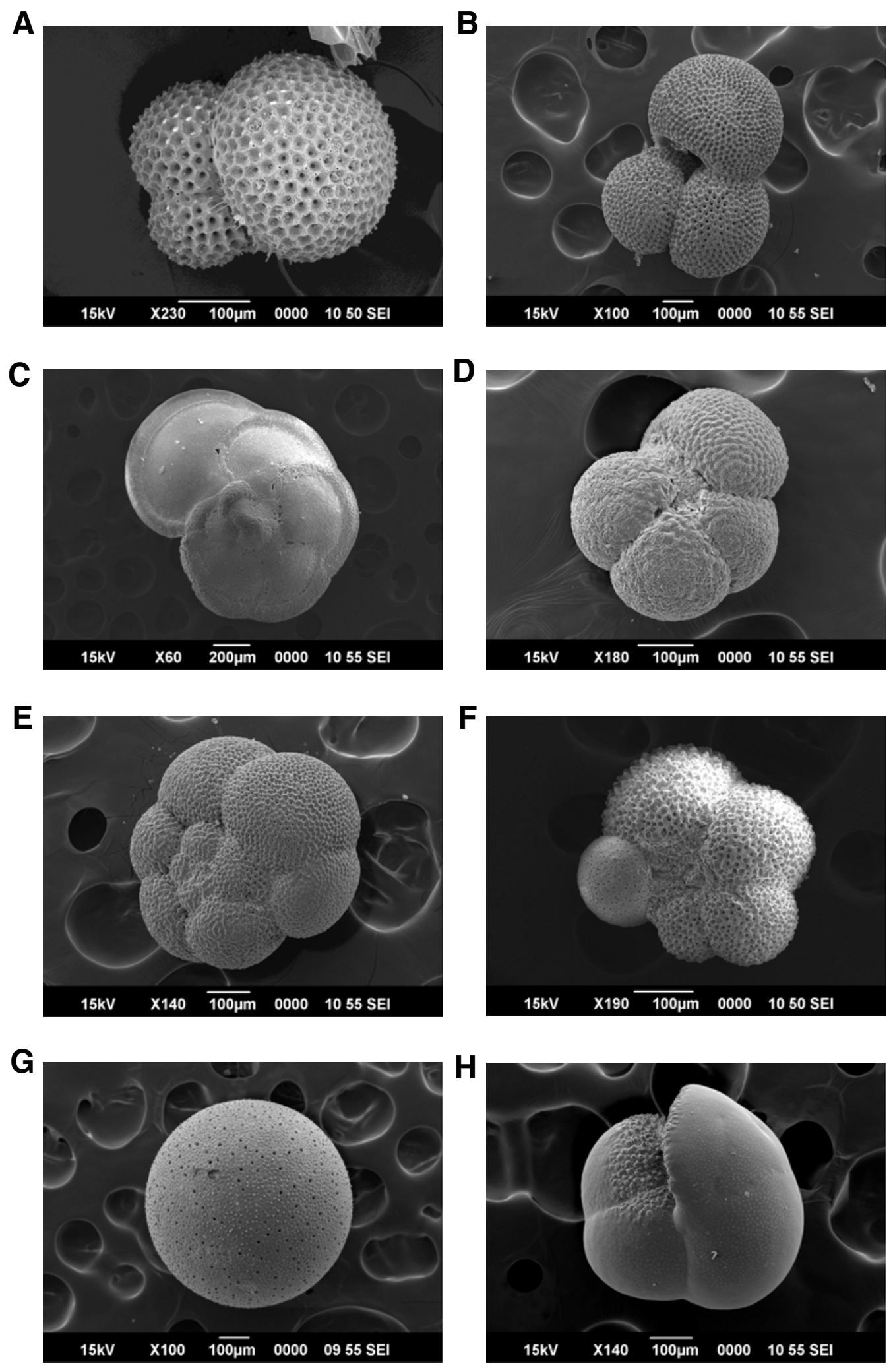
Figure F11. Series of SEM photomicrographs of pyritized foraminifers from Sample 331-C0014A-1H-4, 130-132 $\mathrm{cm}$ (4.1 mbsl). A-C. Proximal and distal views of Neogloboquadrina eggeri and Orbulina universa demonstrate the high degree of preservation of these "fossilized" microfossils. D. A cracked Orbulina universa microfossil demonstrates that these pyritized foraminifers are hollow. At higher magnification (area of box in D), the pyrite was observed to be (E) generally framboidal in nature and (F) ordered at high magnification (backscattered SEM), although not, as yet, crystallized into well-ordered framboidal pyrite.
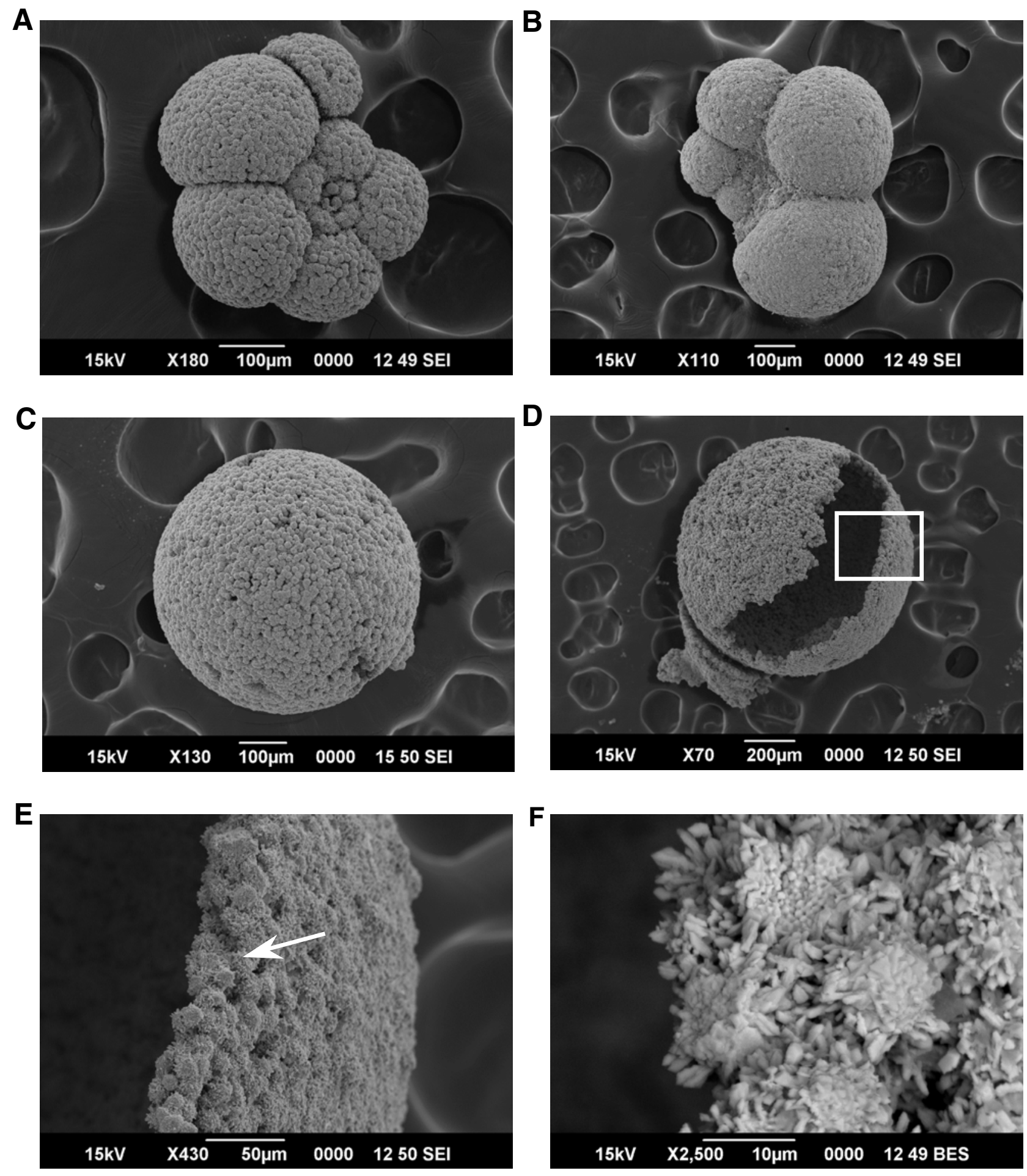
Figure F12. A. SEM photomicrographs of an aggregate of framboidal pyrite from Sample 331-C0014A-1H-4, $130-132 \mathrm{~cm}(4.1 \mathrm{mbsf})$, possessing juvenile forms of pyritized foraminifers that are only clearly visible at high magnification (B, C). B. Area of box in A. C. Area indicated by arrow in A.
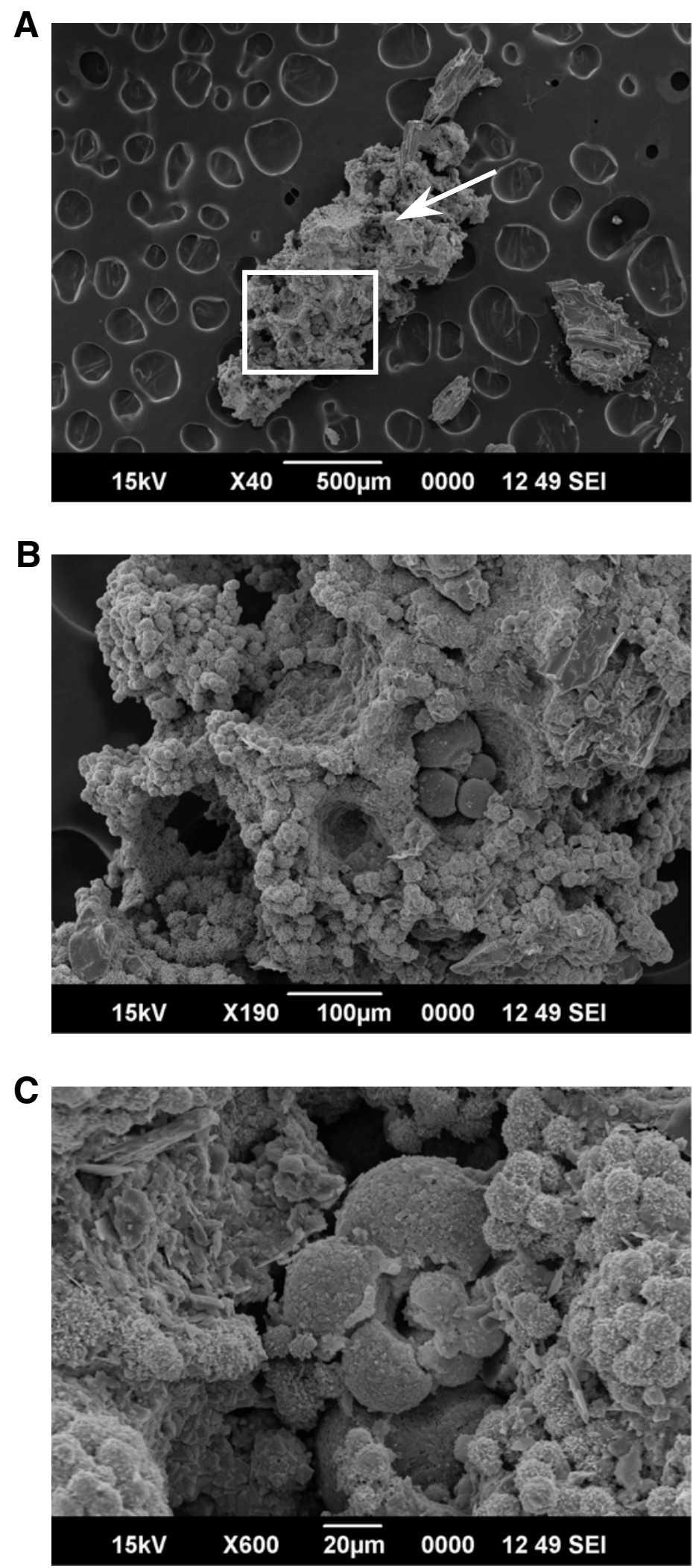
Figure F13. SEM photomicrographs of the dominant coccoliths observed on smear slides prepared from (A-C) Sample 331-C0014A-1H-1, 1-2 cm (0.01 mbsf), and (D) Sample 331-C0014B-1H-CC, 24.5-25.5 cm (7.0 mbsf). Although not exclusive to the deeper sample, note the typical loss of structural integrity (i.e., the bridge in coccoliths recovered from (D) the bottom of Core 331-C0014B-1H versus those recovered from (B) the surface of Core 331-C0014A-1H. A. Emiliania huxleyii var. corona (arrow) and Gephyrocapsa oceanica (two coccoliths). B. Gephyrocapsa oceanica; note preservation of the bridge. C. Emiliania huxleyii var. huxleyii. D. Gephyrocapsa oceanica.
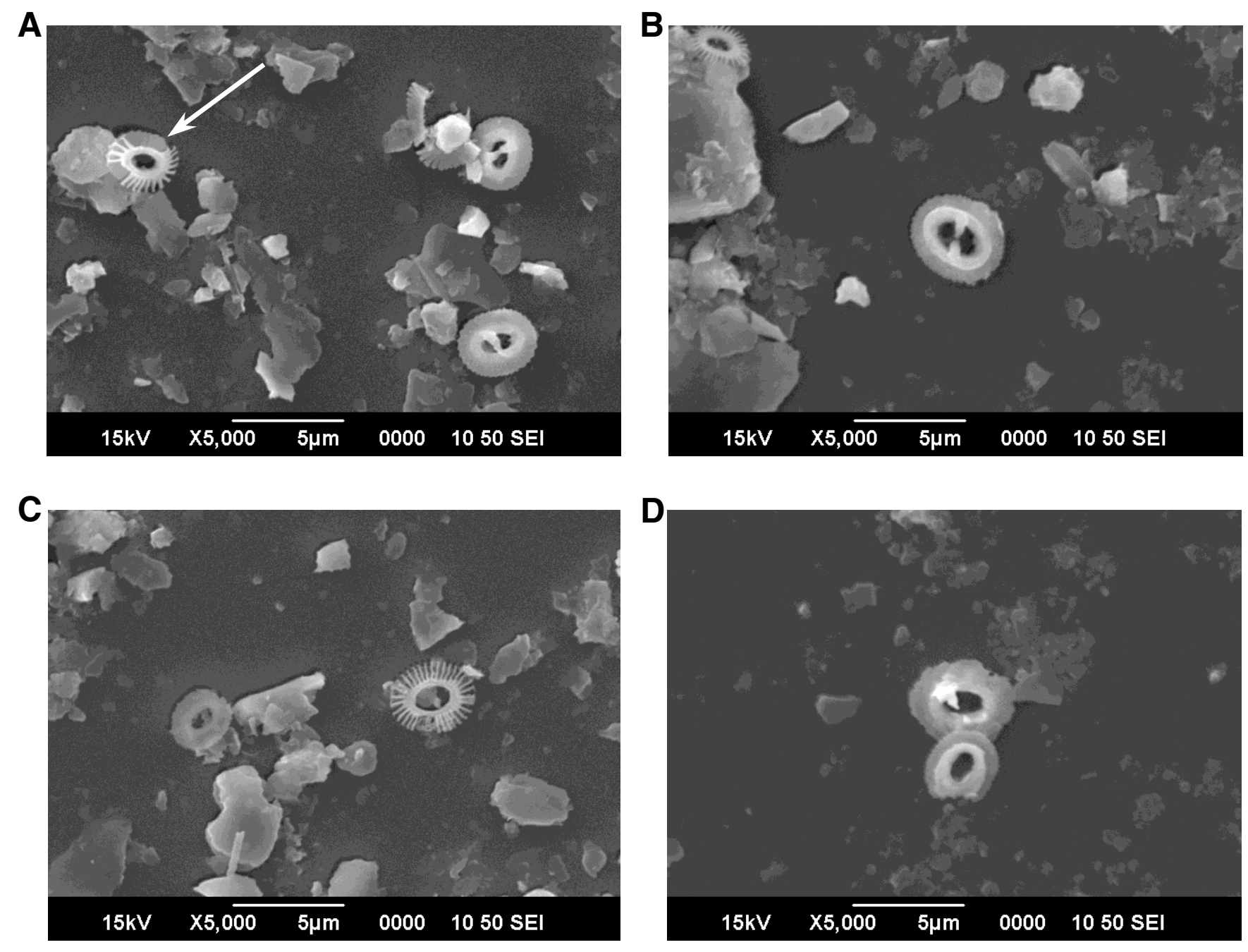
Figure F14. SEM photomicrographs of radiolarians observed in the 63-150 $\mu \mathrm{m}$ sieved fraction recovered from Sample 331-C0014A-1H-1, 1-2 cm (0.01 mbsf). A. Thecosphaera sp. B. Conchidium. C. Stylacontarium. D. Haeckeliella sp. E. Actinomma sp. F. Theocorys sp.

A

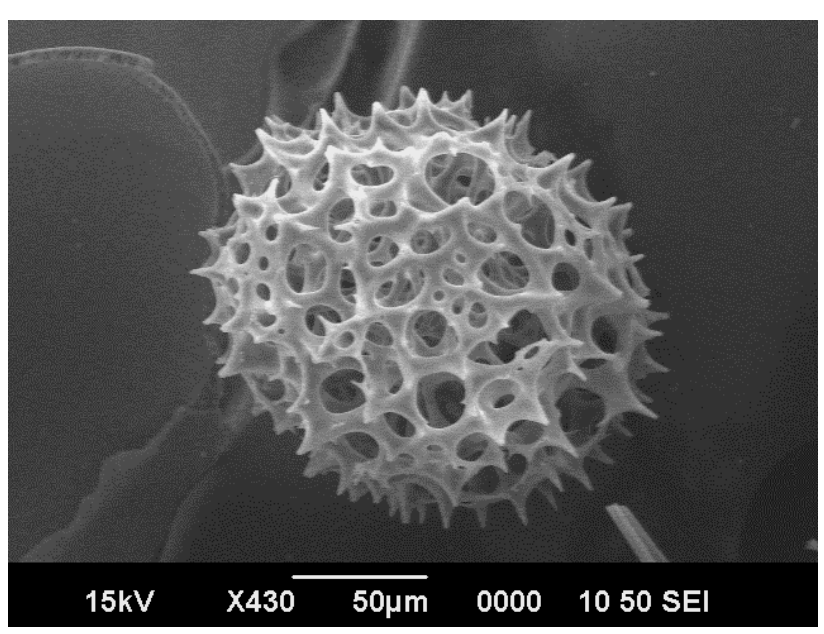

C

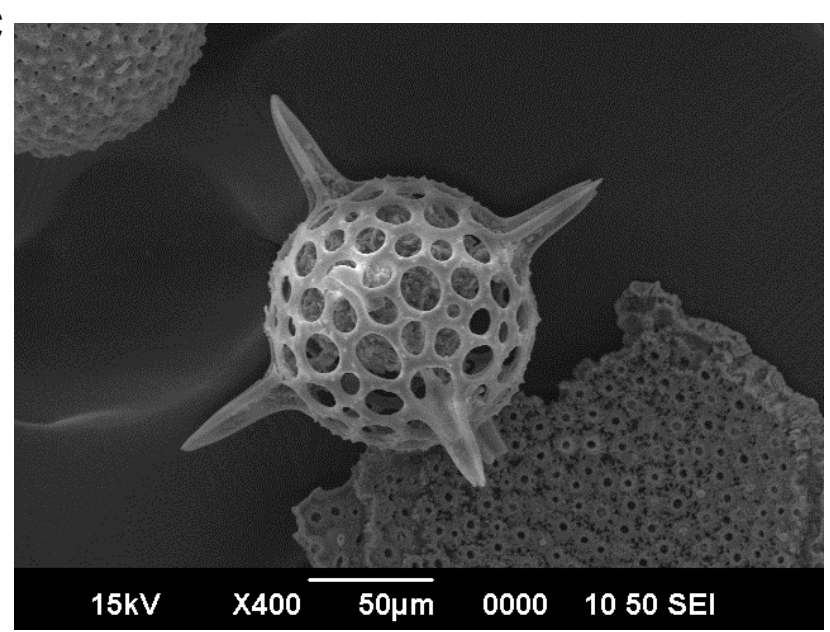

$\mathbf{E}$

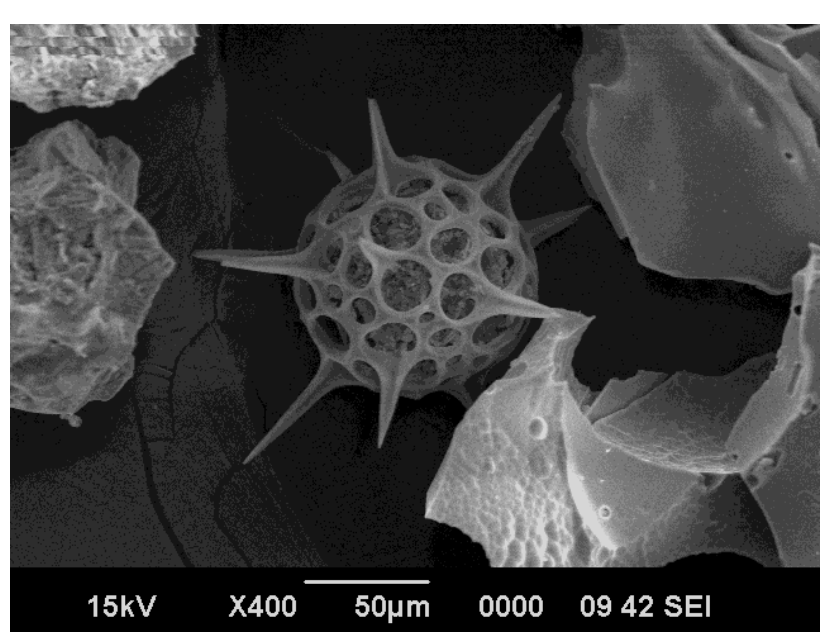

B

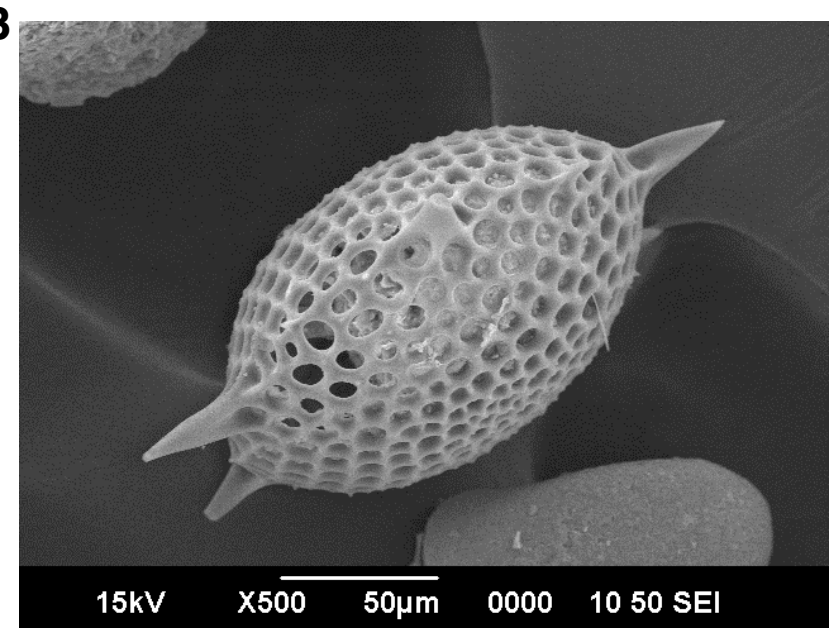

D

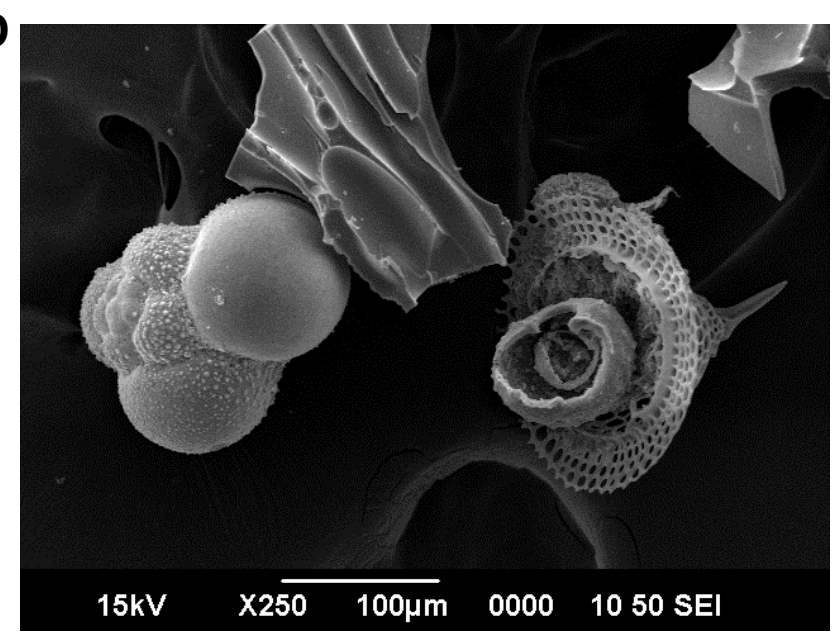

$\mathbf{F}$

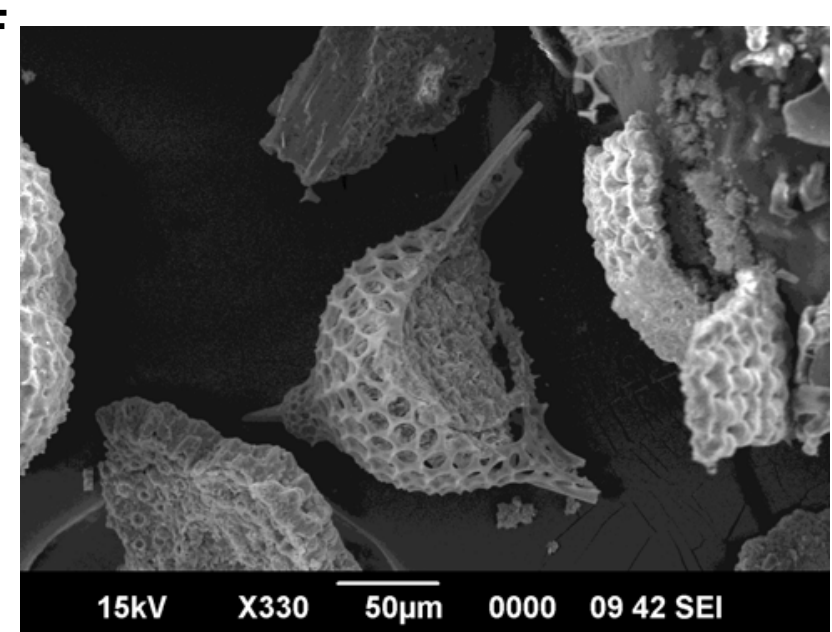


Figure F15. Summary of alteration assemblages identified at Site C0014.

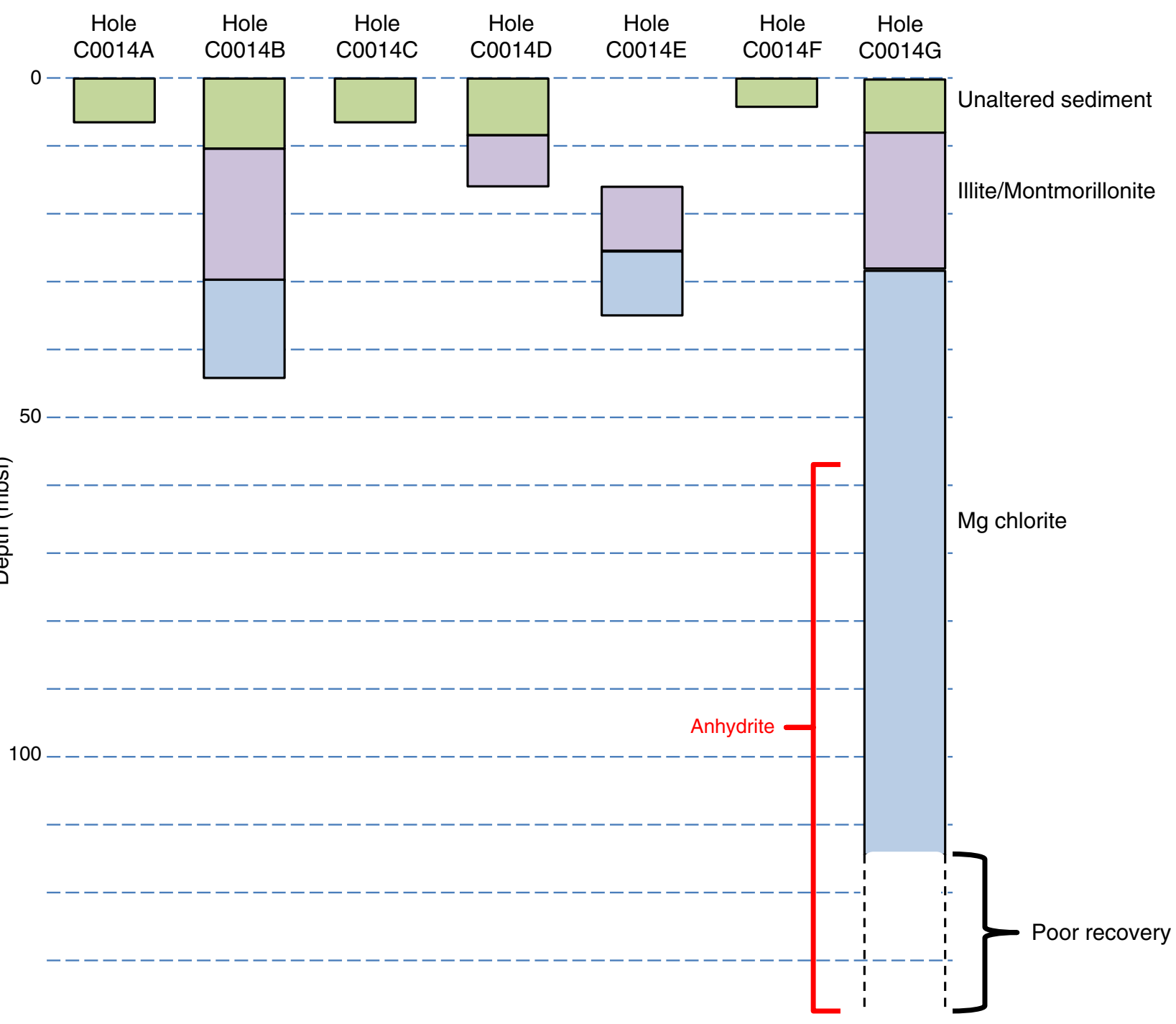


Figure F16. Core photographs showing increasing alteration of pumiceous gravel units downhole at Site C0014. A. Incipient devitrification of pumice clasts and partial alteration of fine-grained matrix to pale clay (interval 331-C0014B-2H-3, 95-114 cm). B. Increased breakdown of pumice structure to soft pale siliceous aggregates with increasing pale clay (interval 331-C0014B-2H-4, 75-94 cm). C. Complete loss of pumice competency (interval 331-C0014B-2H-5, 70-89 cm). D. Remnant pseudoclastic texture after pumice (pale mottling) in clay (interval 331-C0014B-3H-2, 18-37 $\mathrm{cm})$.
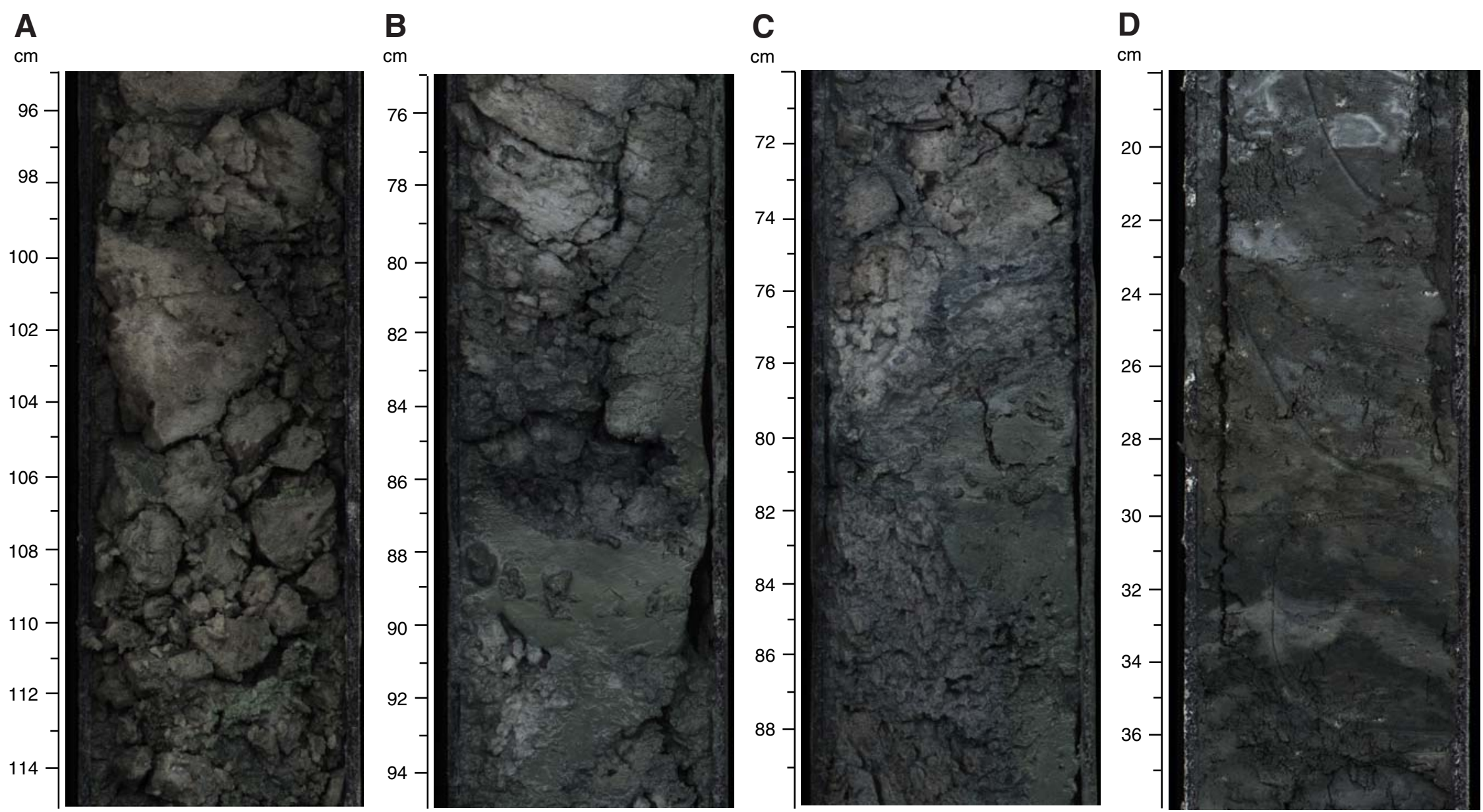
Figure F17. Backscattered SEM photomicrographs of the surface of a coarse anhydrite crystal from Sample 331C0014G-18T-3, 91.0-91.3 cm, showing (A) dissolution pitting across its surface and (B) fine euhedral pyrite crystals (bright minerals) hosted in the crystal.

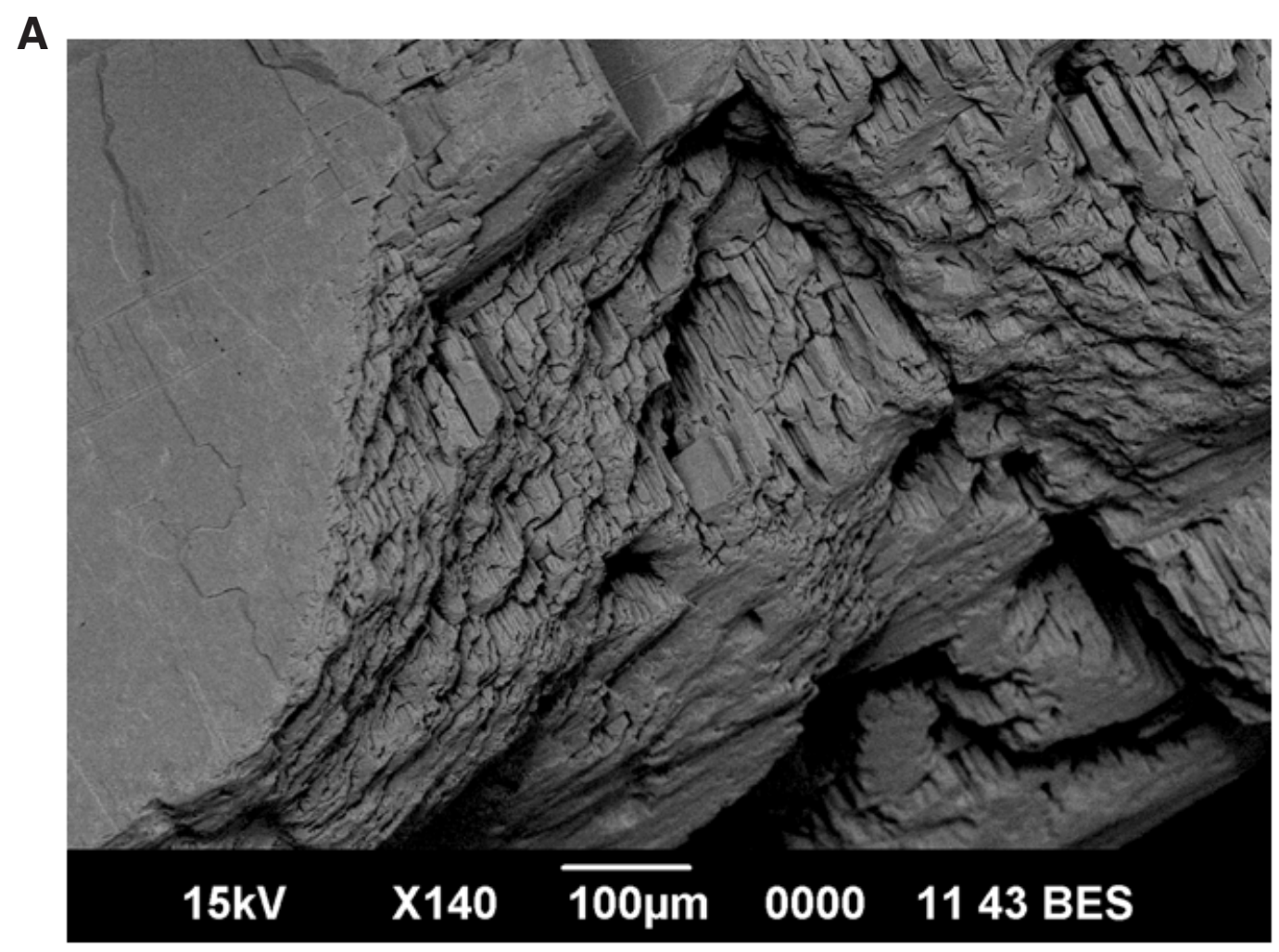

B

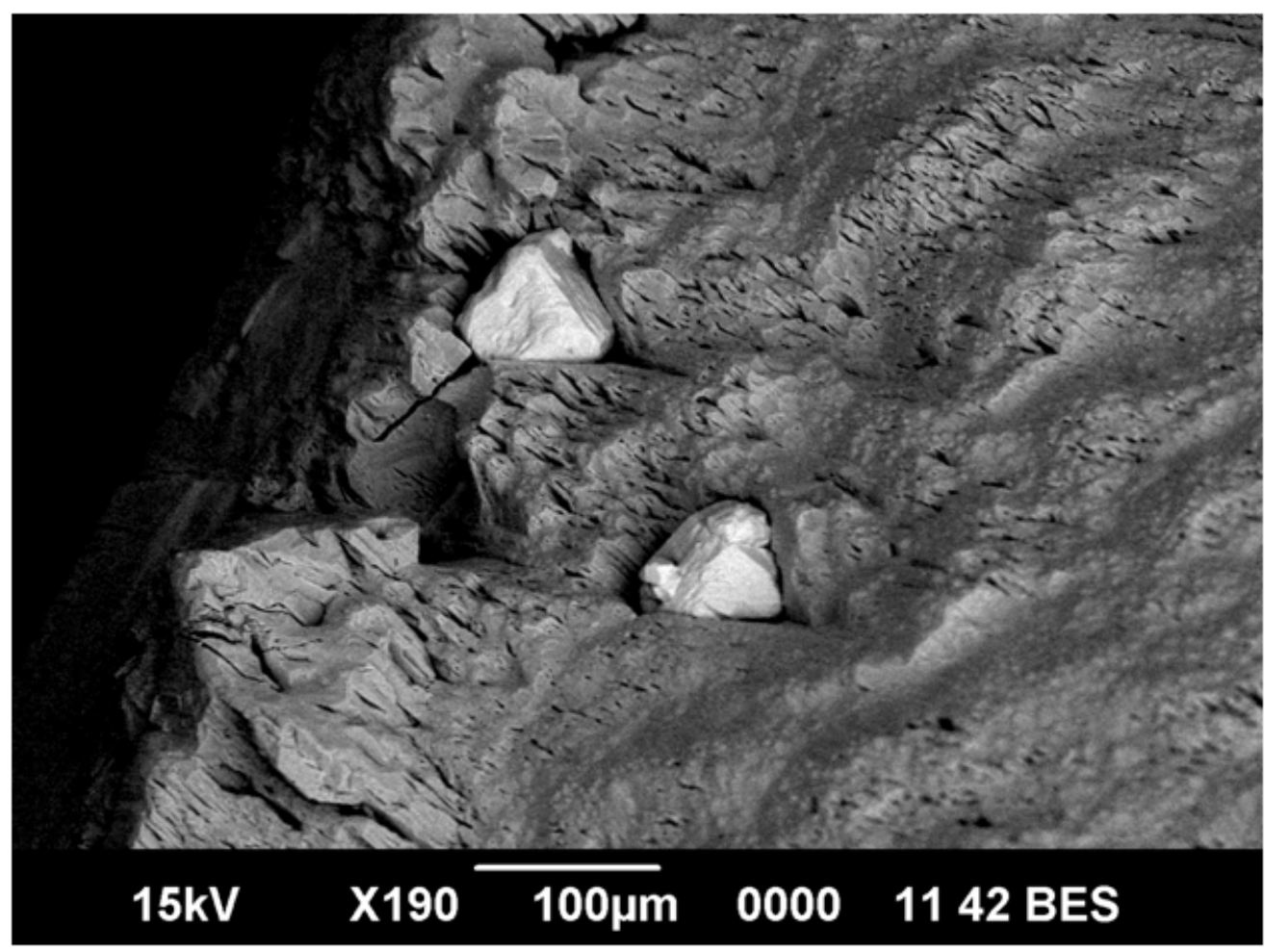


Figure F18. Backscattered SEM photomicrographs of a polymetallic sulfide vein from Sample 331-C0014G-24T1, 2.0-2.1 cm, showing an intergrowth between sphalerite (sp), galena (gn), and chalcopyrite (cp). The inset in (A) is shown in (B).

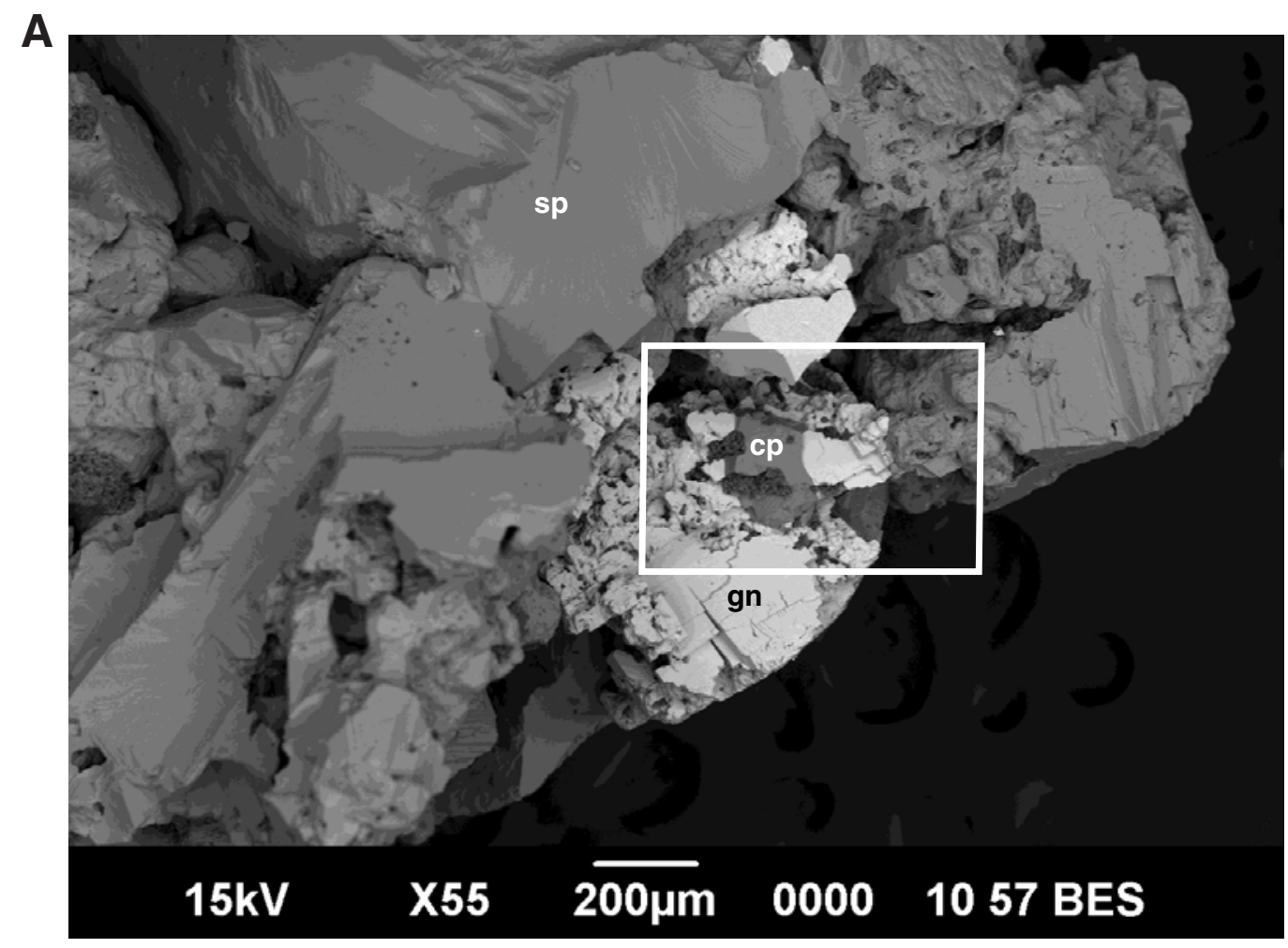

B

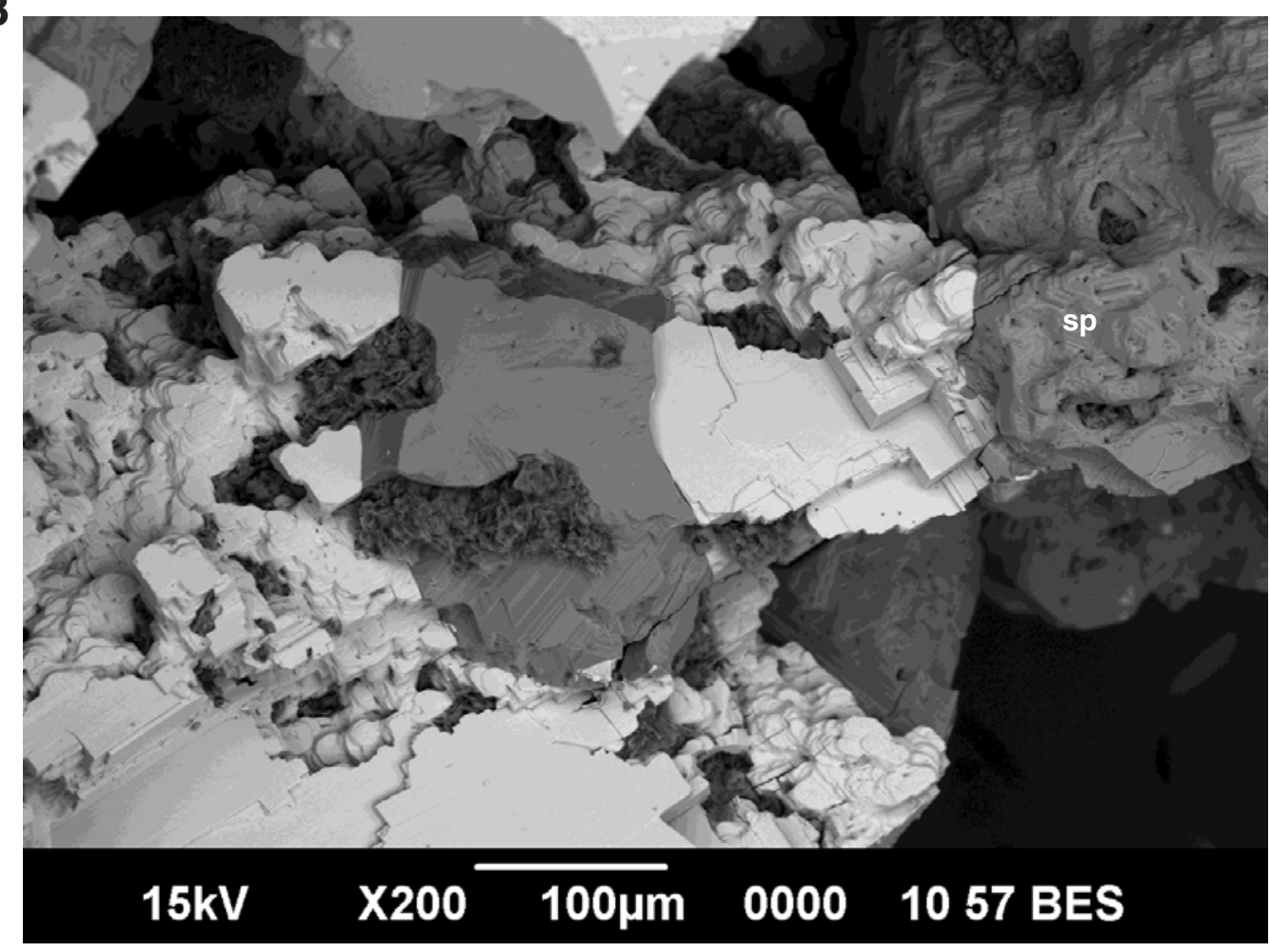


Figure F19. Plot of sodium, sodium to chloride ratio, magnesium, potassium, and calcium in pore water, Site C0014. Sodium is as measured by ion chromatography. Dashed lines represent concentrations in seawater.

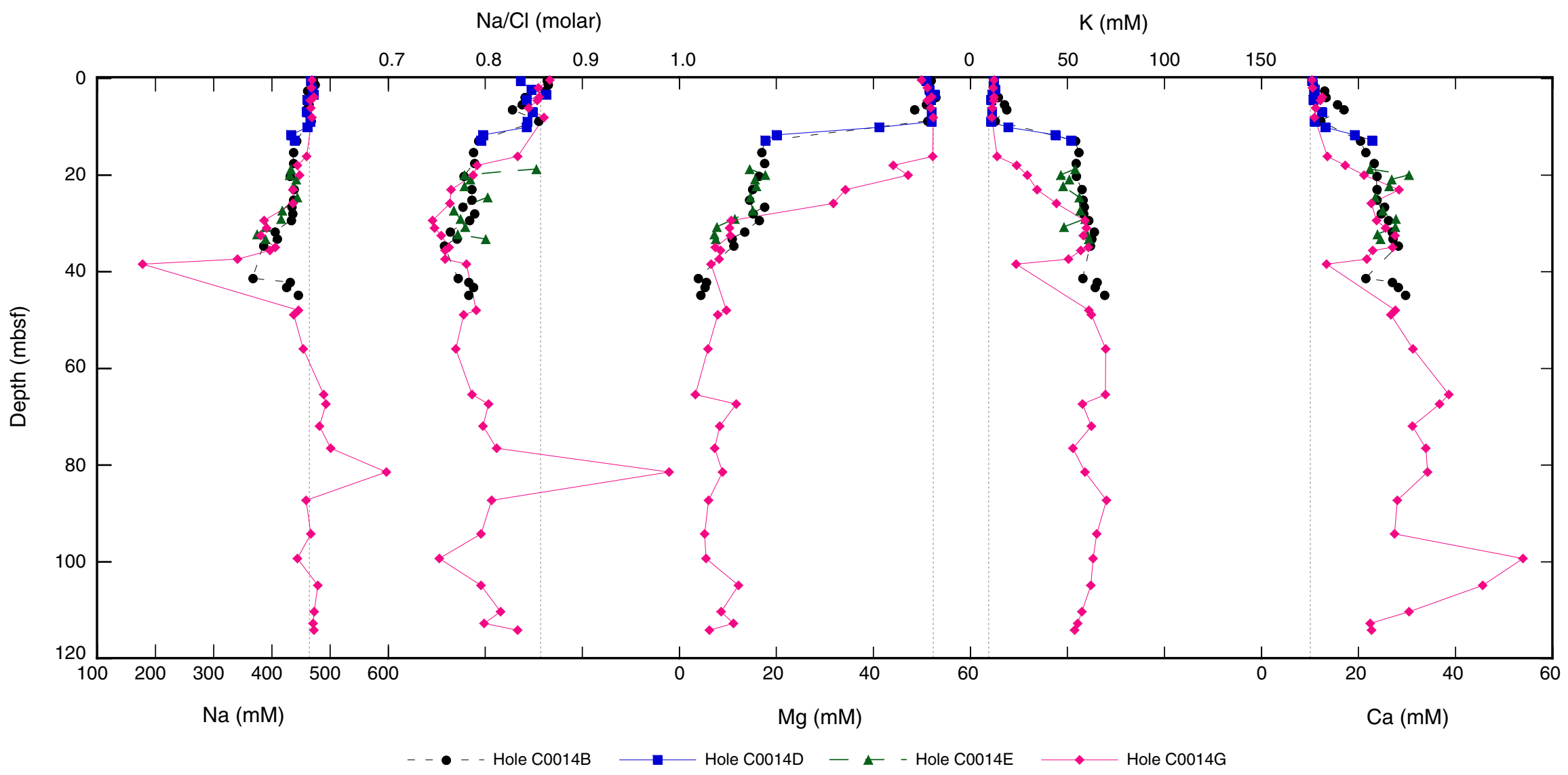


Figure F20. Plot of sulfate in pore water, Holes C0014B, C0014D, C0014E, and C0014G. Arrows indicate concentrations in seawater.

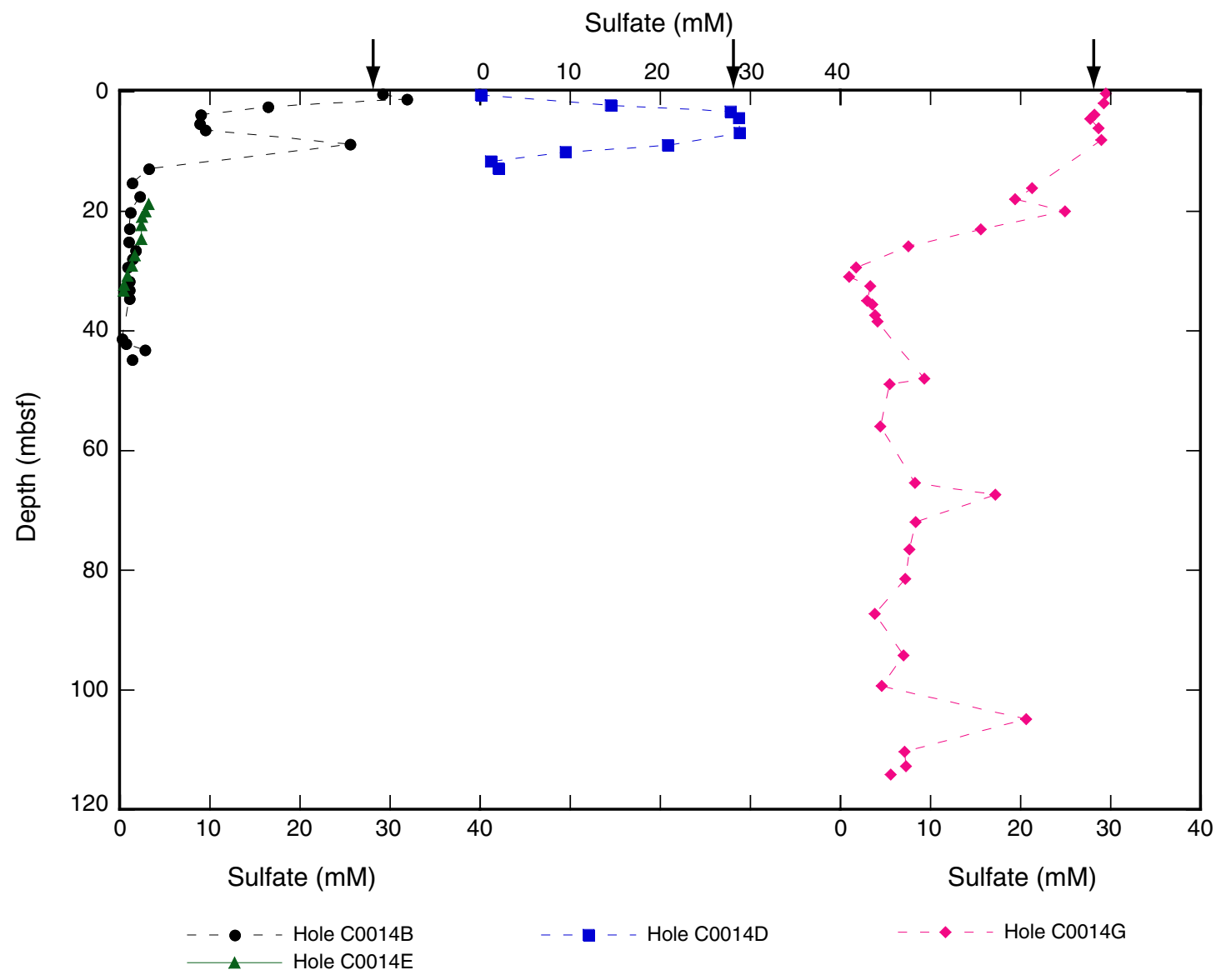




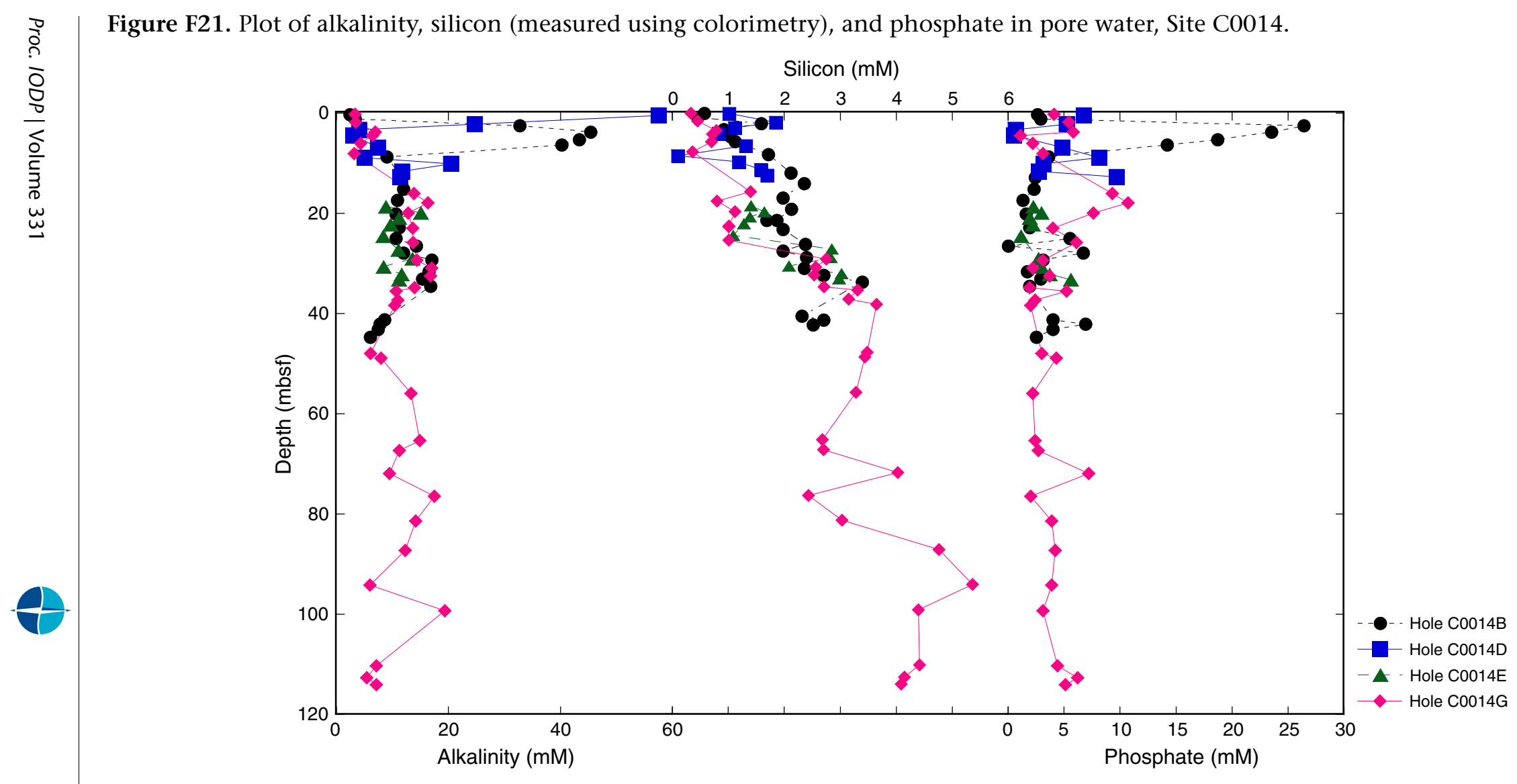




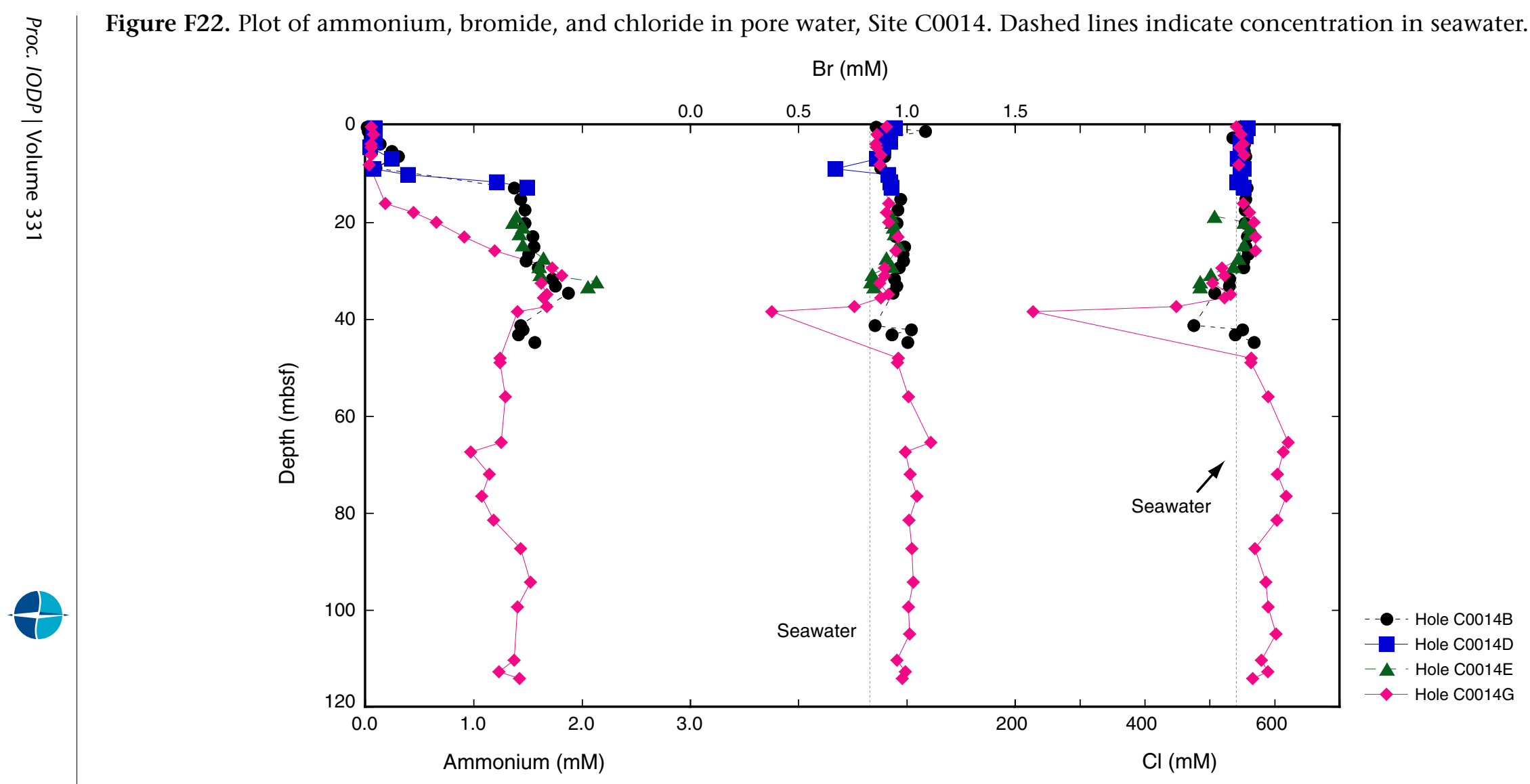


Figure F23. Plot of hydrocarbons in headspace gas, Site C0014. A. Methane concentration in science gas samples. B. Methane concentration in safety gas samples. C. Methane/ethane ratio in safety gas and void gas samples.

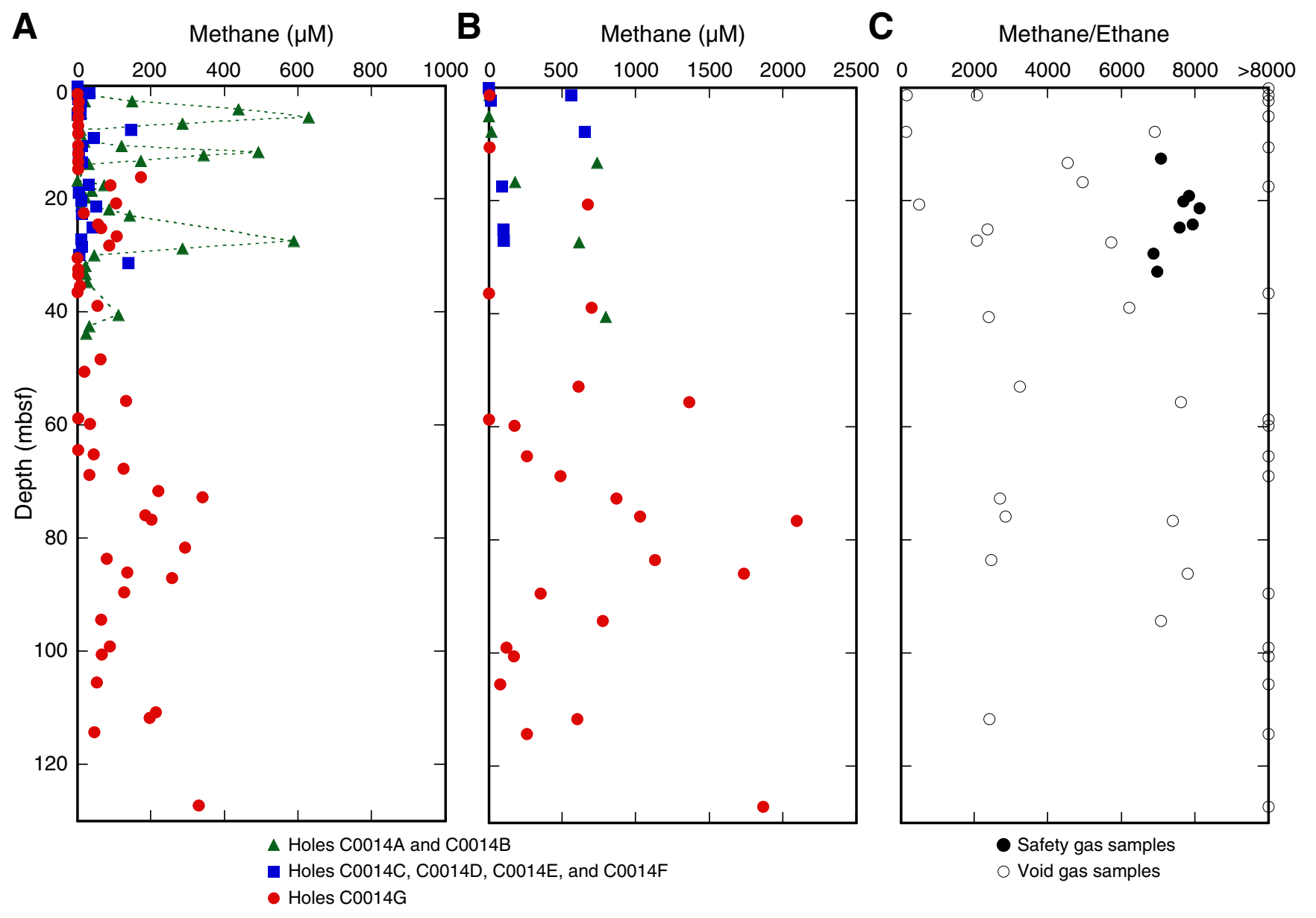




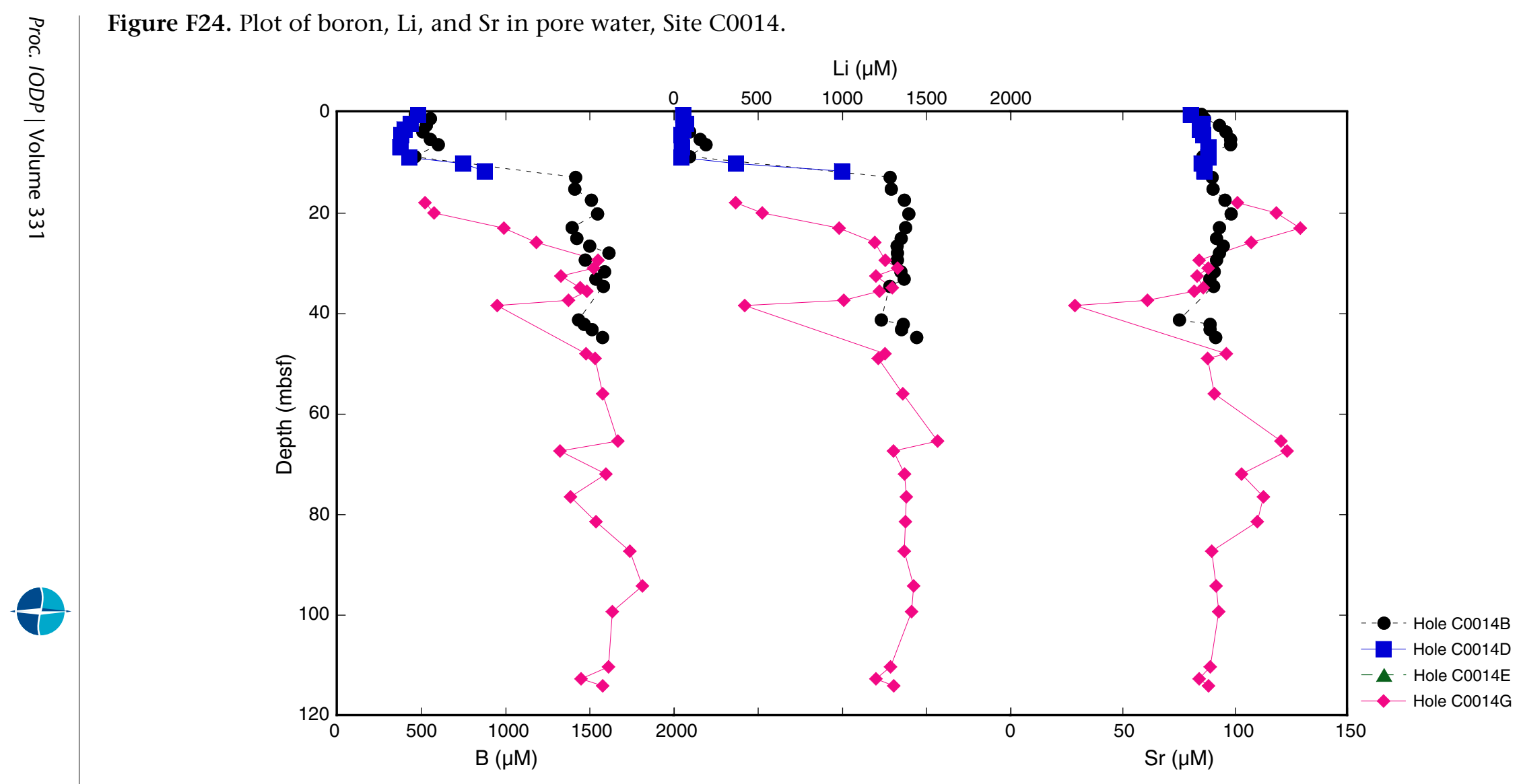




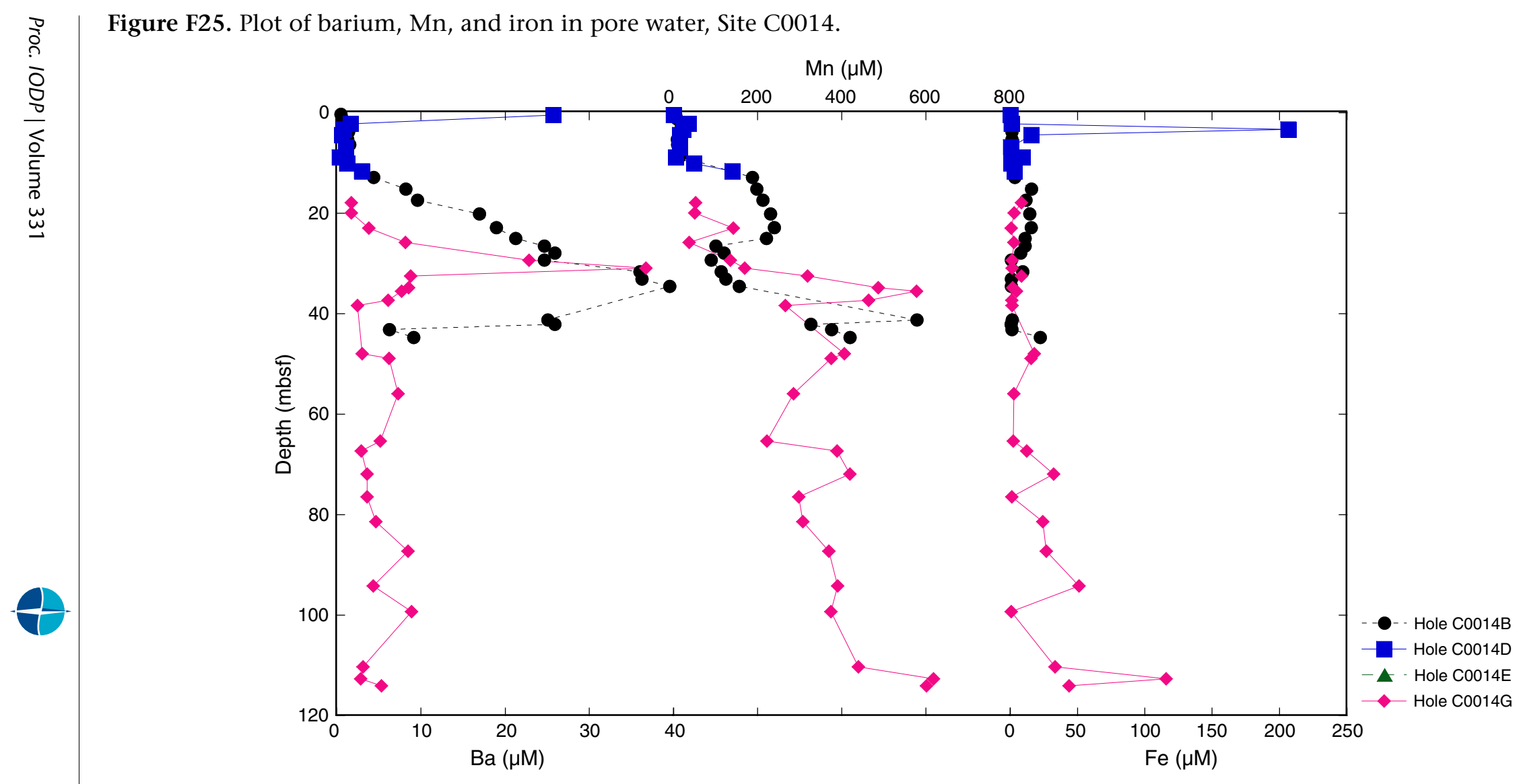


Figure F26. Depth profiles of hydrogen in science headspace gas samples. A. Holes C0014C, C0014D, and C0014E, in which plastic liners were used. B. Holes C0014F and C0014G, in which aluminum liners were used. Some samples were analyzed for a second time after two days. Slimy samples probably contain a significant amount of drill fluid. $\mathrm{BD}=$ below detection.

A

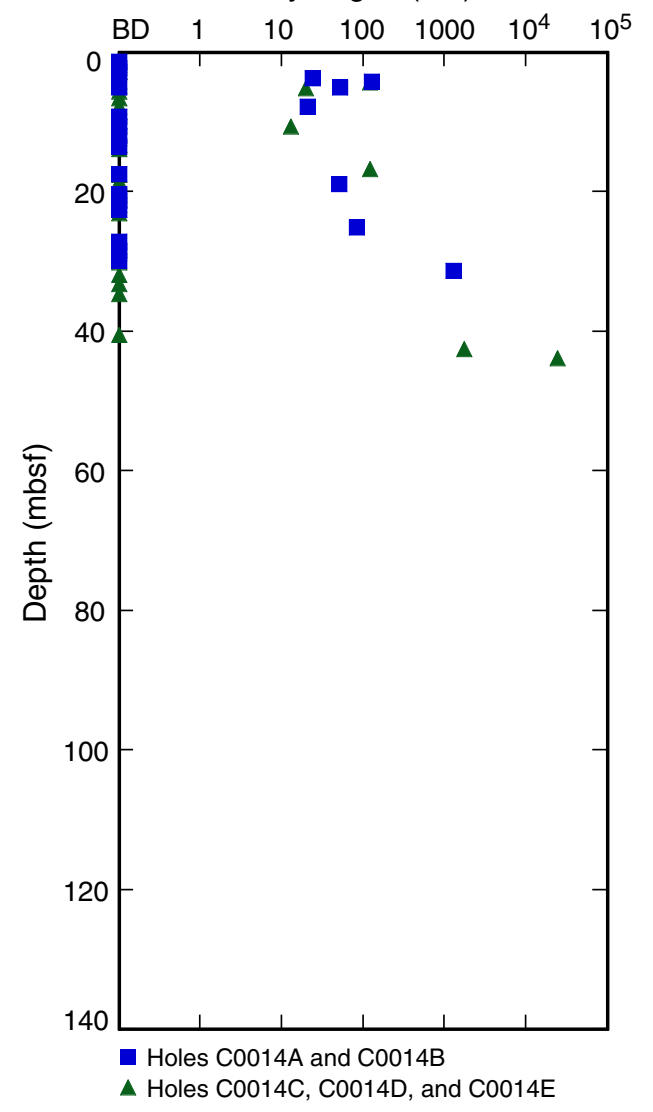

B

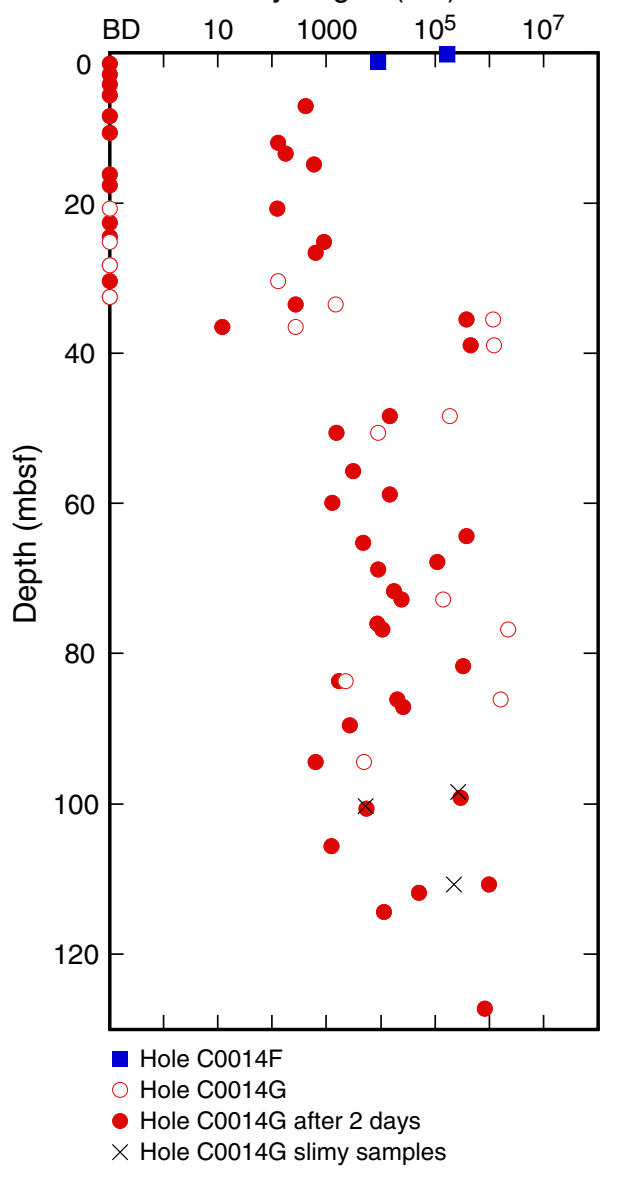


Figure F27. Plot of $\mathrm{CaCO}_{3}$ concentration in sediment, Site C0014.

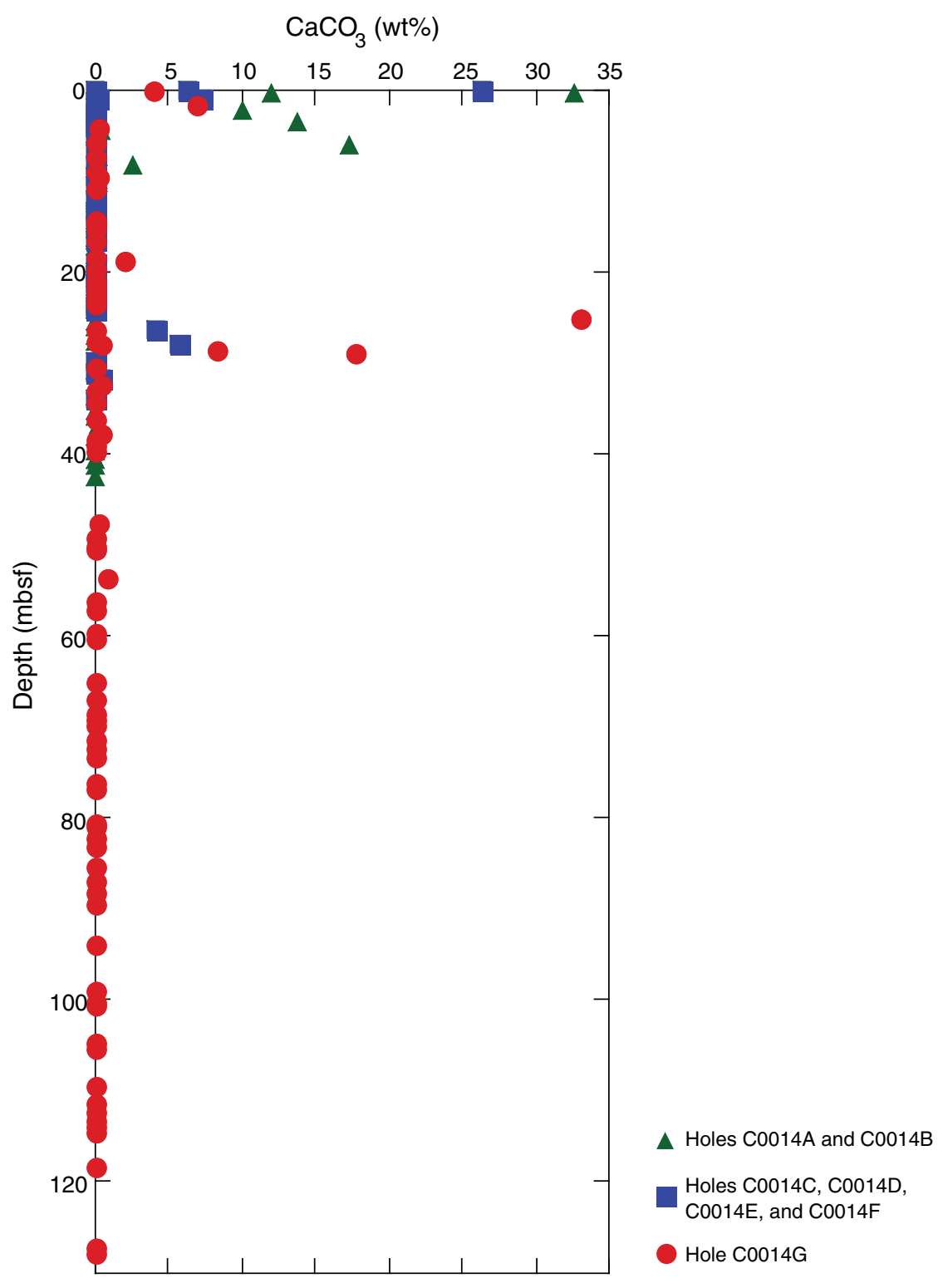


Figure F28. Plot of total organic carbon (TOC; logarithmic), total nitrogen (TN; logarithmic), and total sulfur (TS) concentrations in sediment, Site C0014. $\mathrm{BD}=$ below detection.
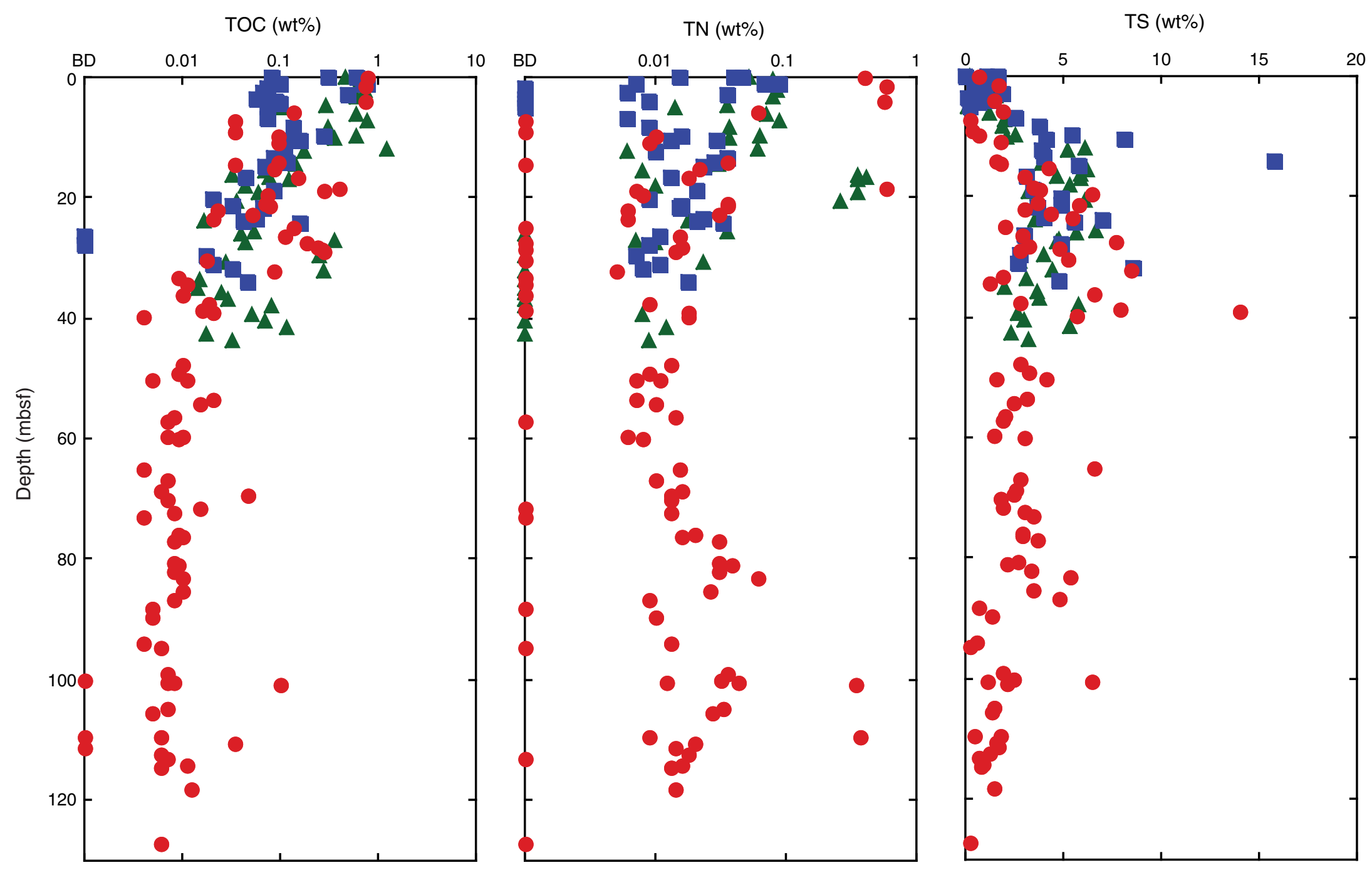

$\Delta$ Holes C0014A and C0014B

Holes C0014C, C0014D, C0014E, and C0014F

Hole C0014G 
Figure F29. Plot of microbial cell counts from Site C0014. Sediment samples from Hole C0014E are shown as triangles. Open symbols indicate that cell abundance is below the detection limit of $1 \times 10^{6}$ to $4 \times 10^{6} \mathrm{cells} / \mathrm{mL}$.

Hole C0014B

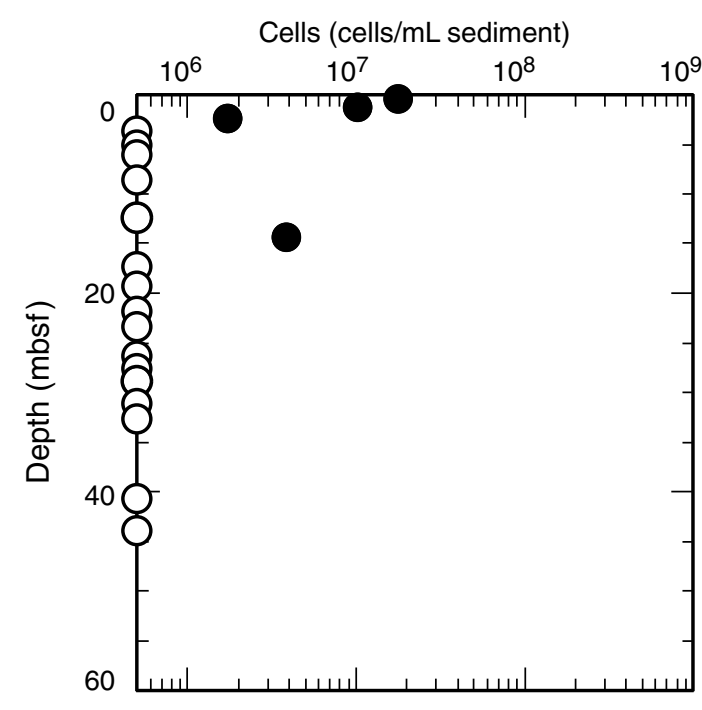

Holes C0014D and C0014E

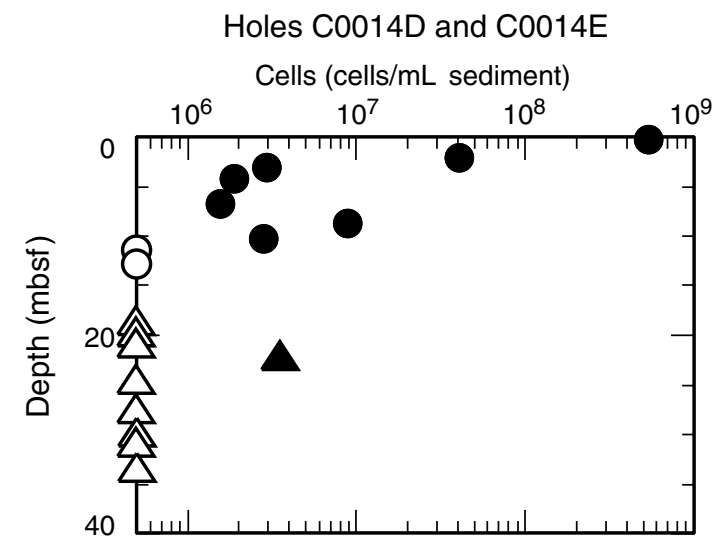

Hole C0014G

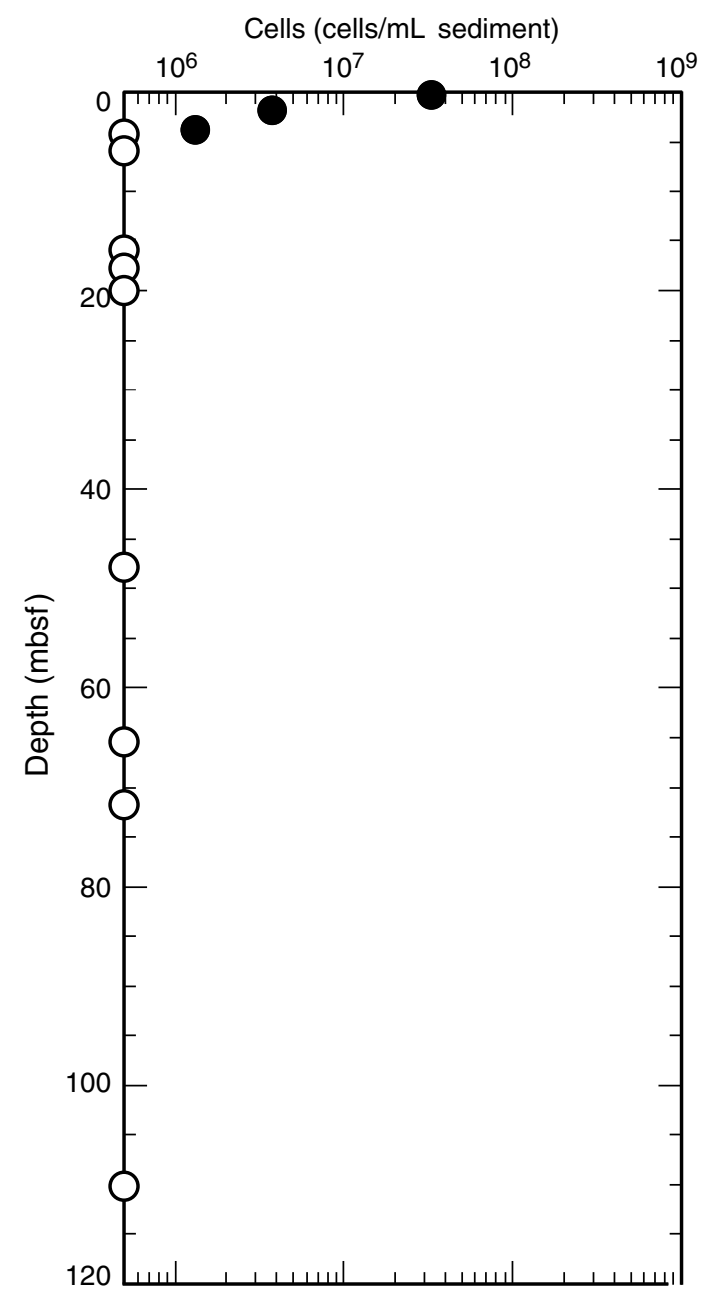


Figure F30. Paired photomicrograph images using epifluorescent (A, C) and brightfield (B, D) microscopy. Arrows indicate the location of putative FeOB. Photomicrographs from Section 331-C0014B-1H-1 ASW media A are shown.
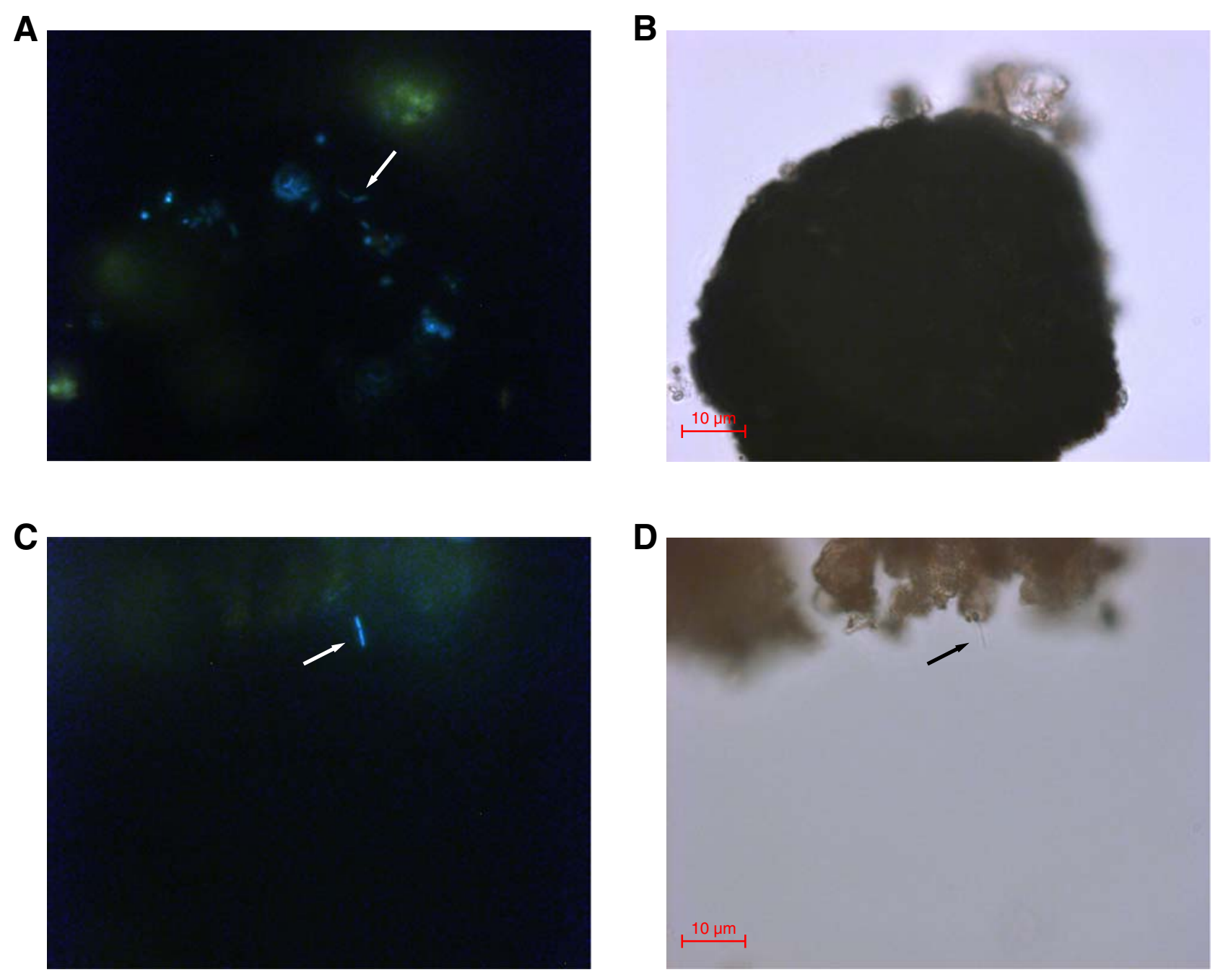
Figure F31. Plot of discrete measurements of bulk density (large solid symbols) and GRA-derived bulk density (small open symbols) from the MSCL-W, Site C0014. GRA-derived bulk density values $<0 \mathrm{~g} / \mathrm{cm}^{3}$ are omitted for clarity.

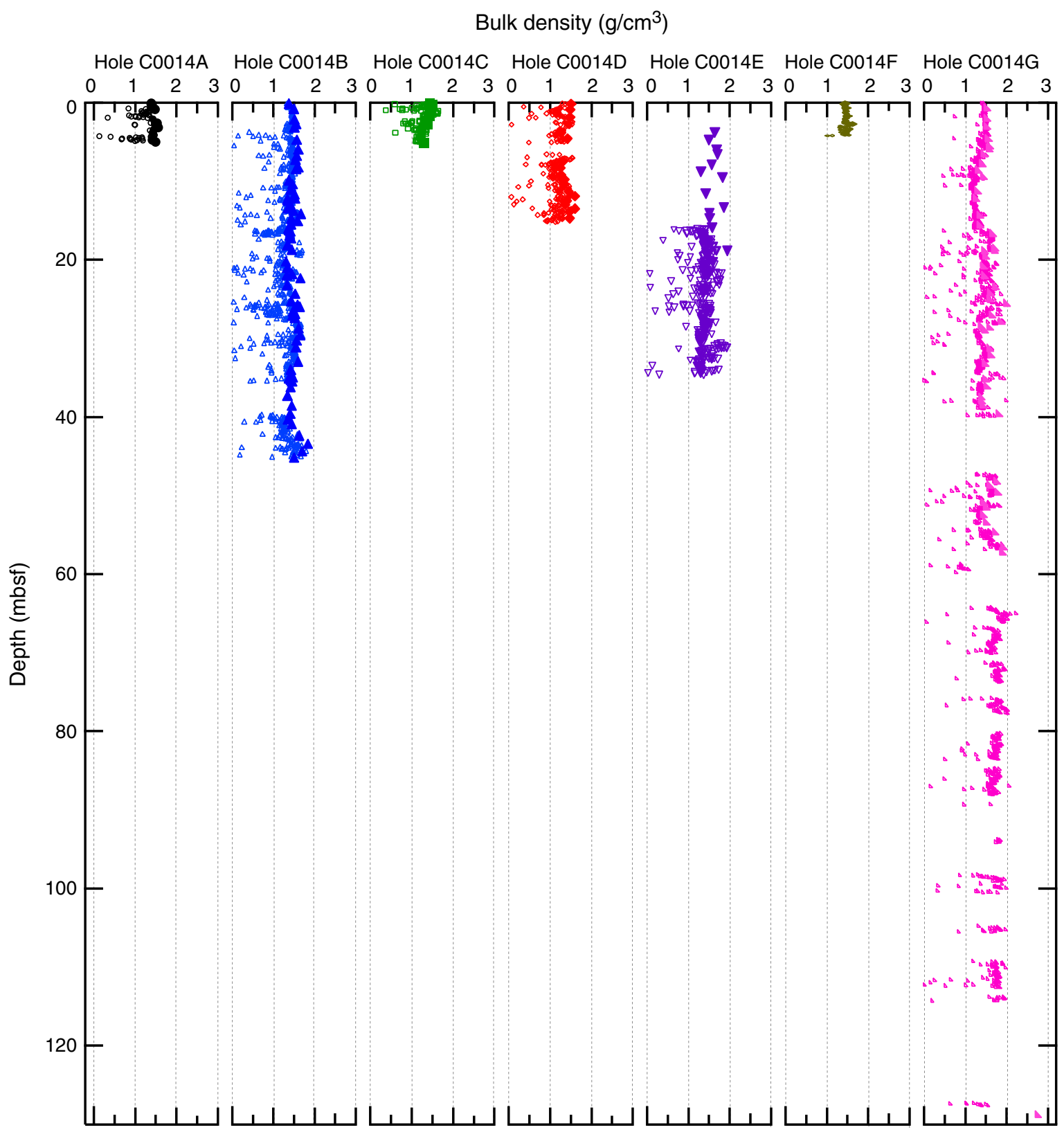


Figure F32. Plot of porosity calculated from discrete MAD measurements, Site C0014.

\section{Porosity (\%)}

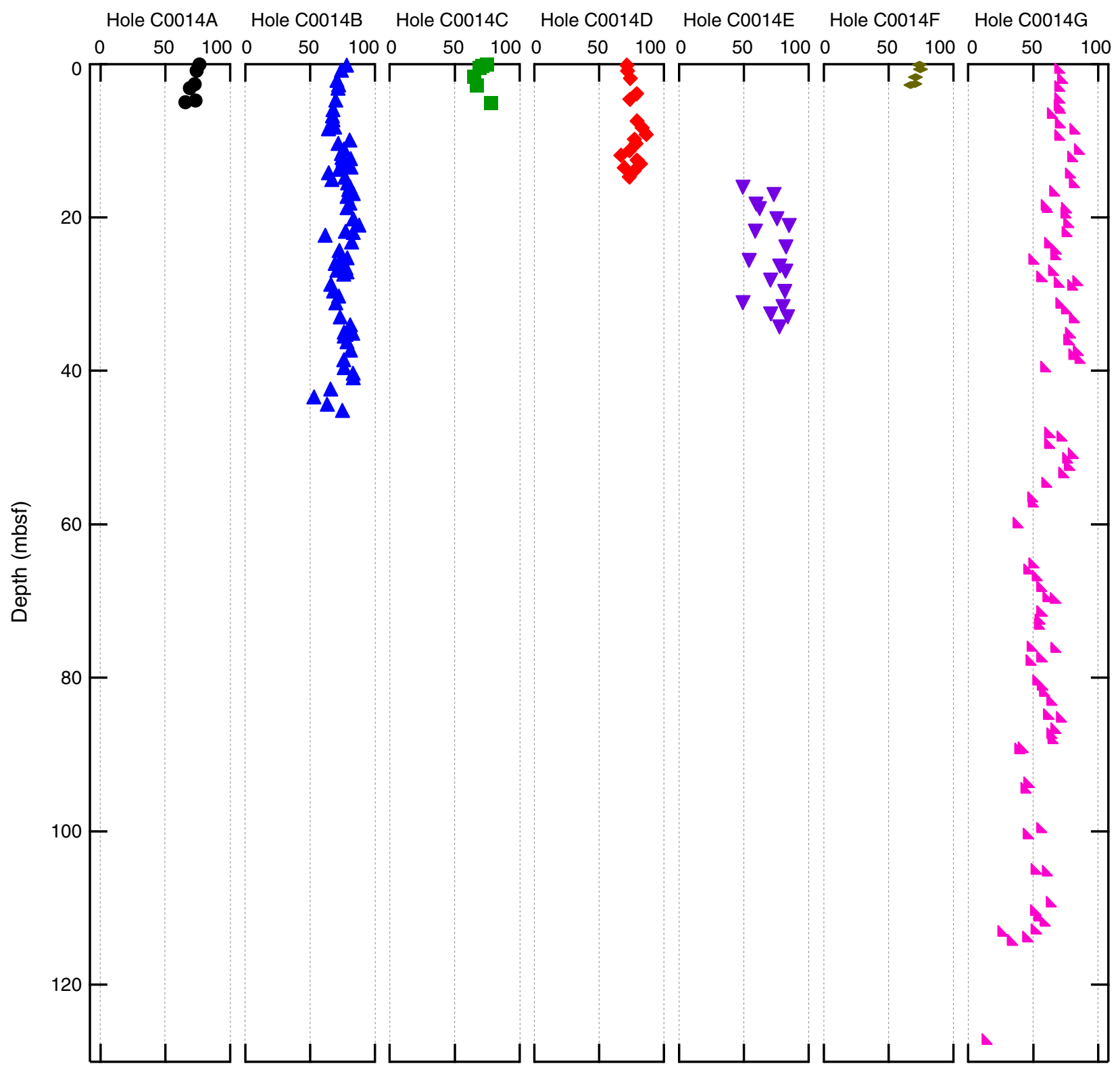


Figure F33. Plot of formation factors calculated from discrete electrical resistivity measurements, Site C0014.

Formation factor

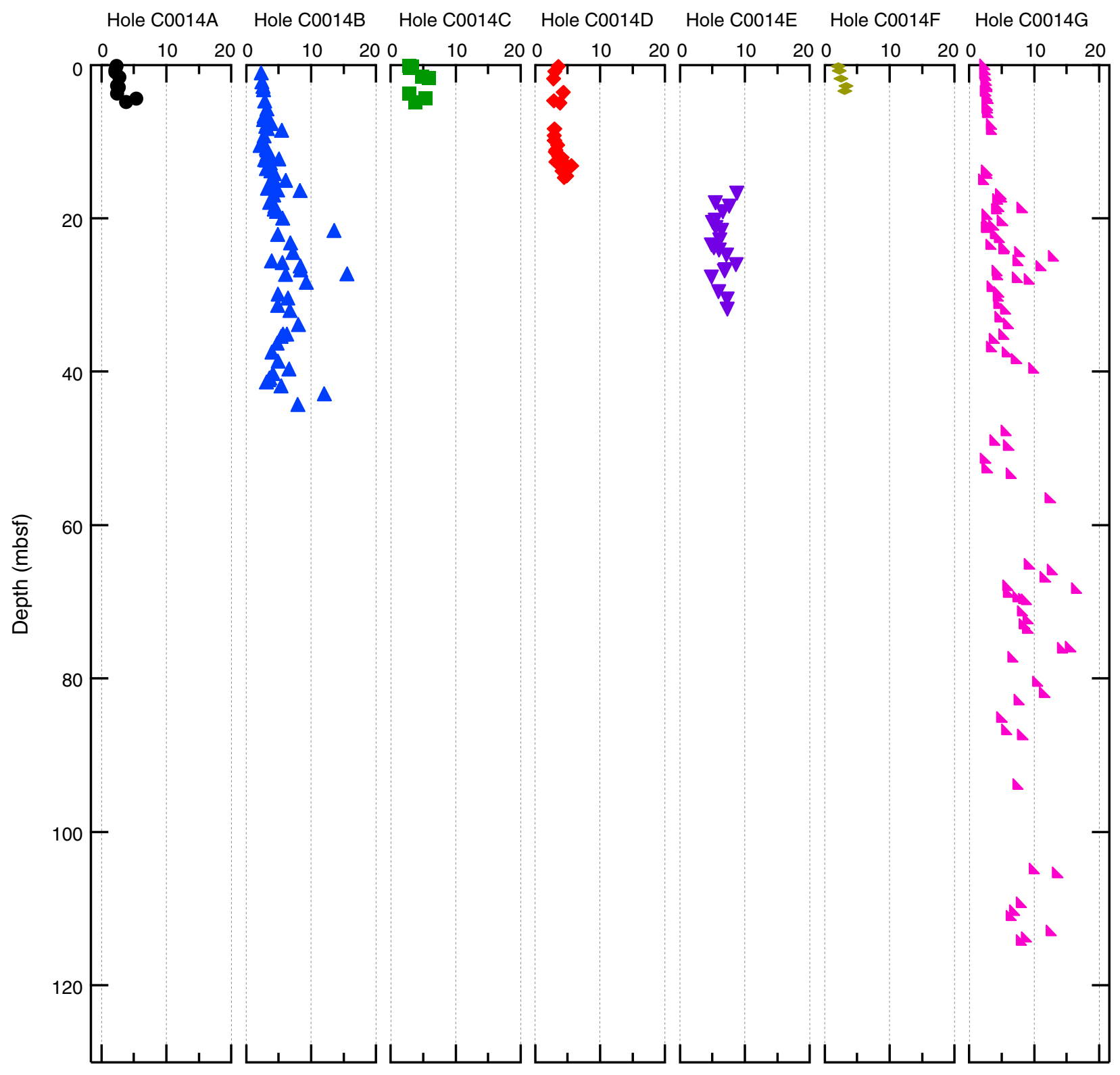


Figure F34. Plot of thermal conductivity, Site C0014.

Thermal conductivity $(\mathrm{W} /[\mathrm{m} \cdot \mathrm{K}])$

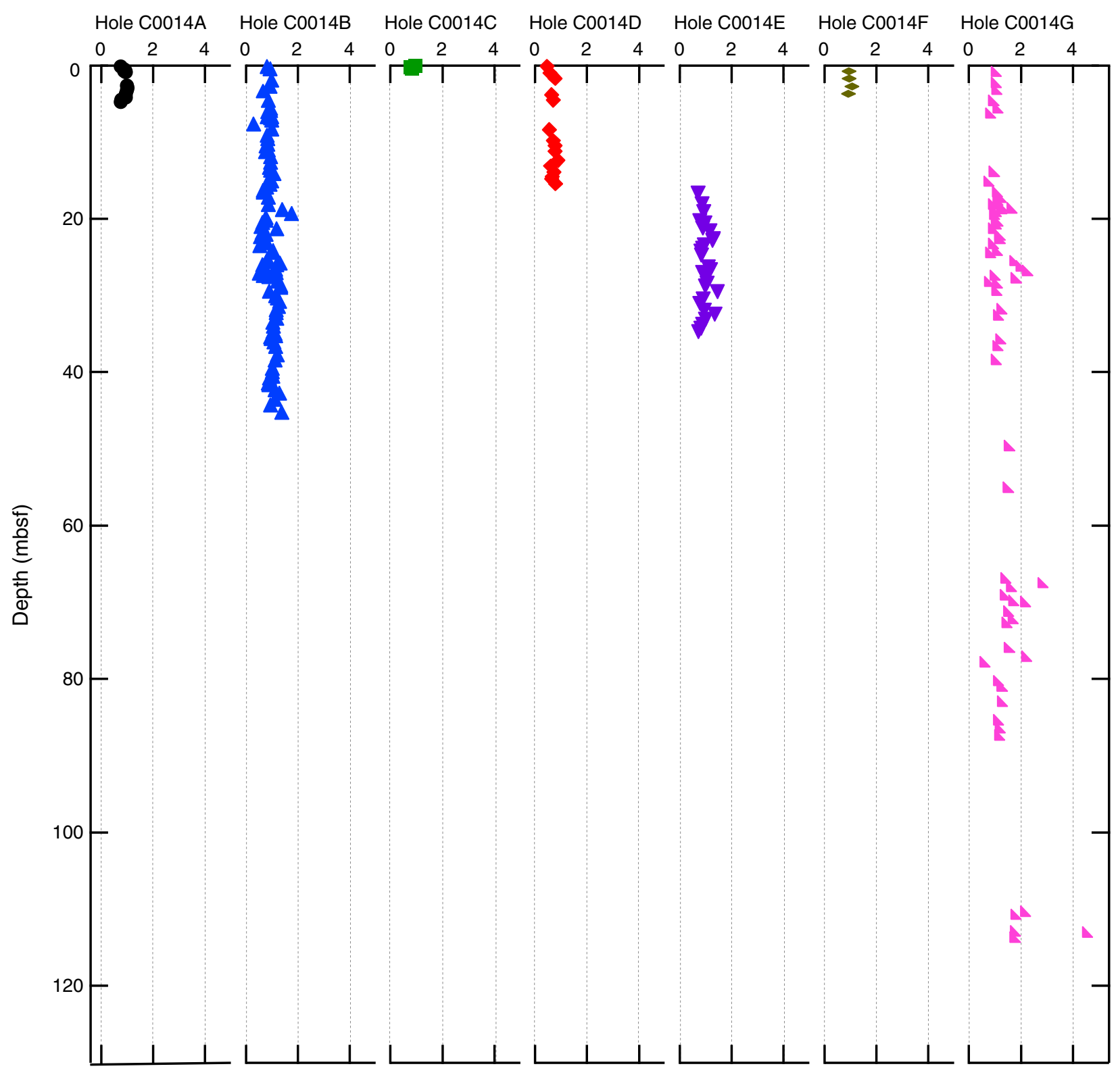


Figure F35. Plot of MSCL-W derived $P$-wave velocity, Site C0014.

$P$-wave velocity $(\mathrm{m} / \mathrm{s})$

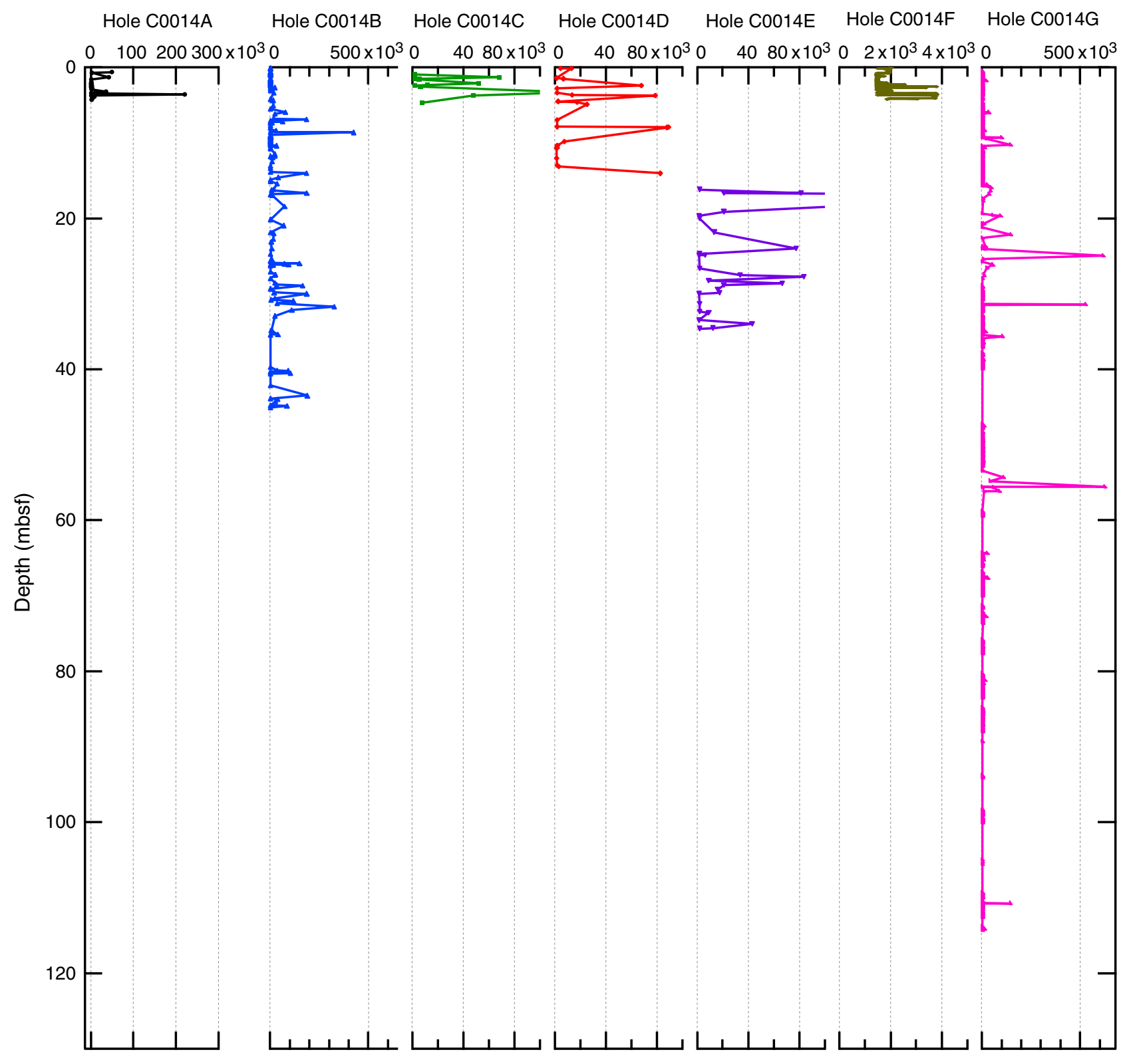


Figure F36. Depth profile of temperature at Site C0014. Equilibrium temperature (red circles) based on APCT3 data. The point at $0 \mathrm{mbsf}$ is the average bottom water temperature. Temperatures at depths greater than $16 \mathrm{mbsf}$ are derived from thermoseal chemically impregnated temperature-sensitive strips (black circles). Points noted by yellow stars are minimum estimates. Error bars on the temperature estimates are smaller than the symbol sizes.

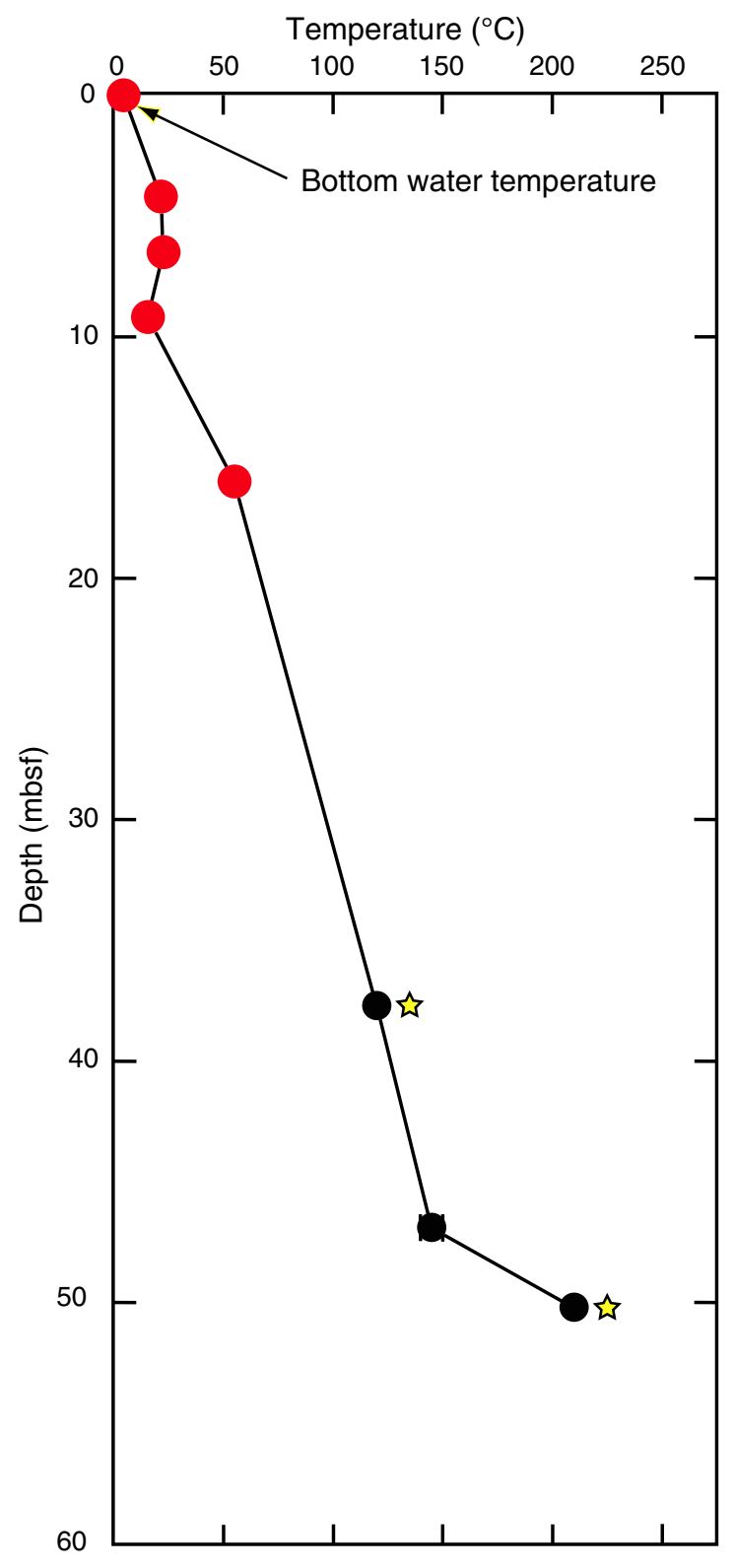


Figure F37. Temperature-time series measured during the deployment of the advanced piston corer temperature tool (APCT3) at Site C0014 (blue line). Unshaded area = data used for equilibrium temperature fit, red line $=$ theoretical equilibrium curve, triangle $=$ beginning of fit, inverted triangle $=$ end of fit, dashed red line with circles = estimate of equilibrium temperature. Note frictional heating at penetration (dashed vertical line). A. Hole C0014F, 4.2 mbsf. B. Hole C0014C, 6.5 mbsf. C. Hole C0014G, 9.2 mbsf. D. Hole C0014D, 16 mbsf.
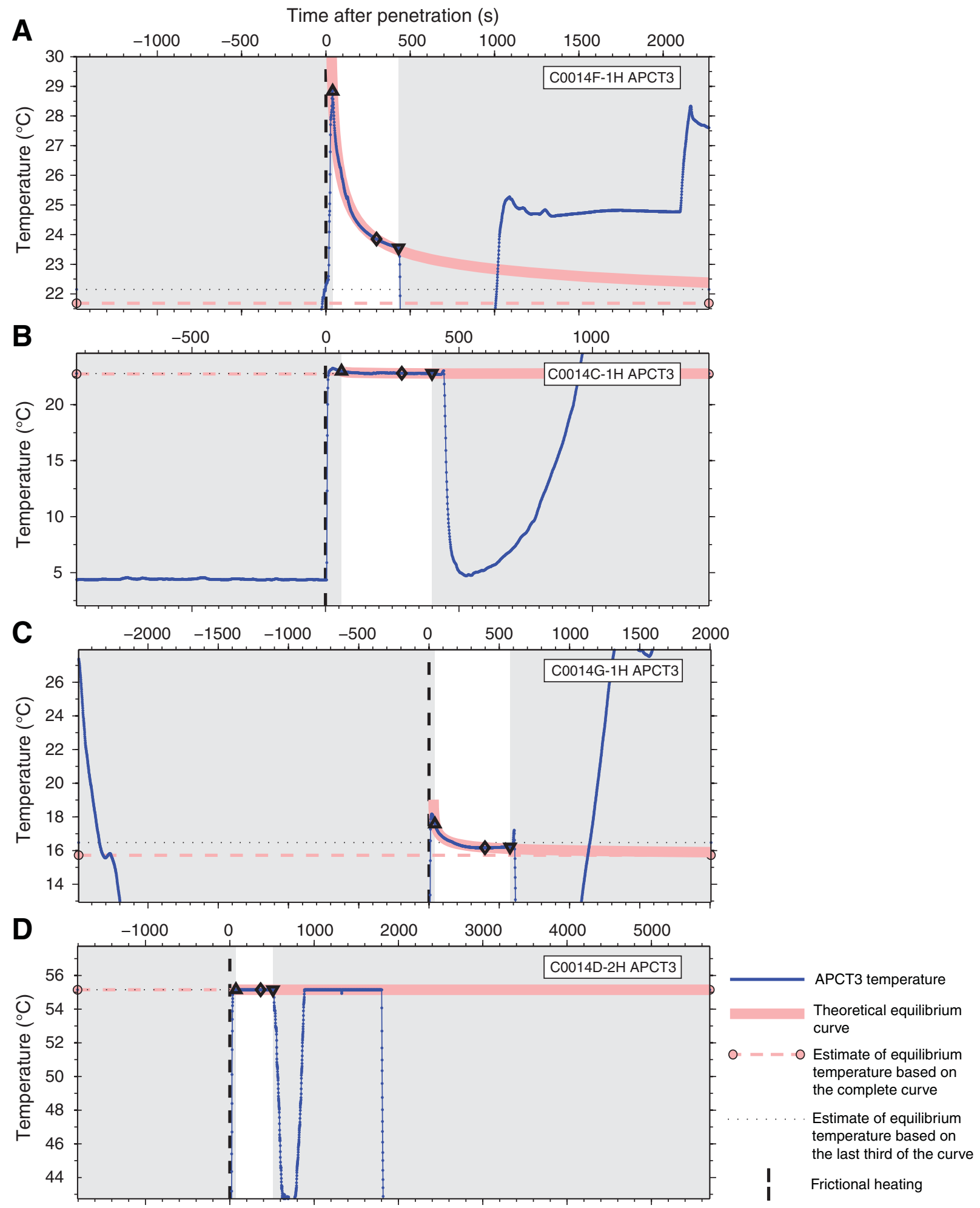
Figure F38. Plot of MSCL-W derived electrical resistivity, Site C0014. No data exist for Holes C0014F and C0014G because of the use of aluminum core liners.

Resistivity $(\Omega \mathrm{m})$

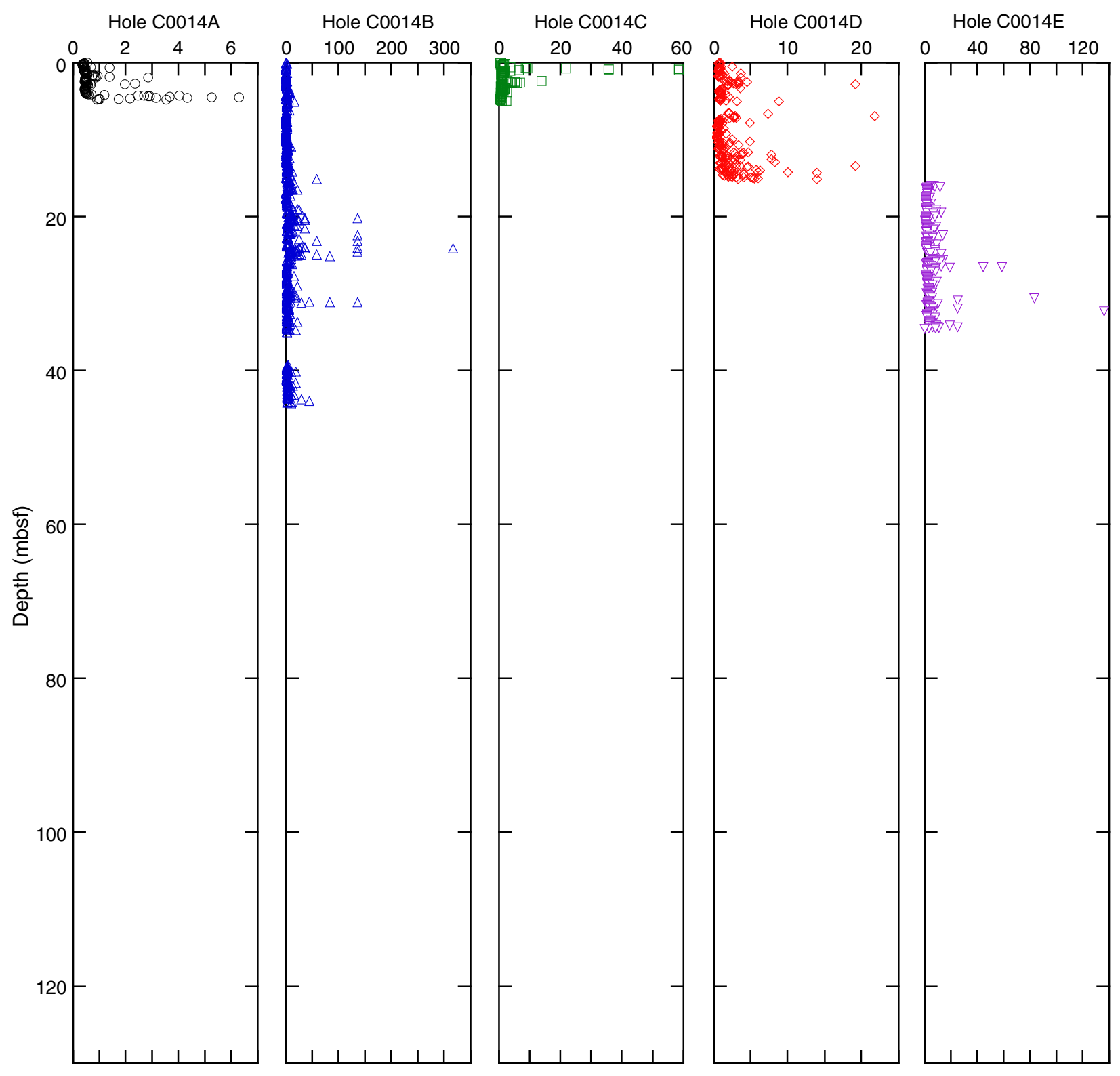


Table T1. Coring summary, Site C0014. (Continued on next two pages.)

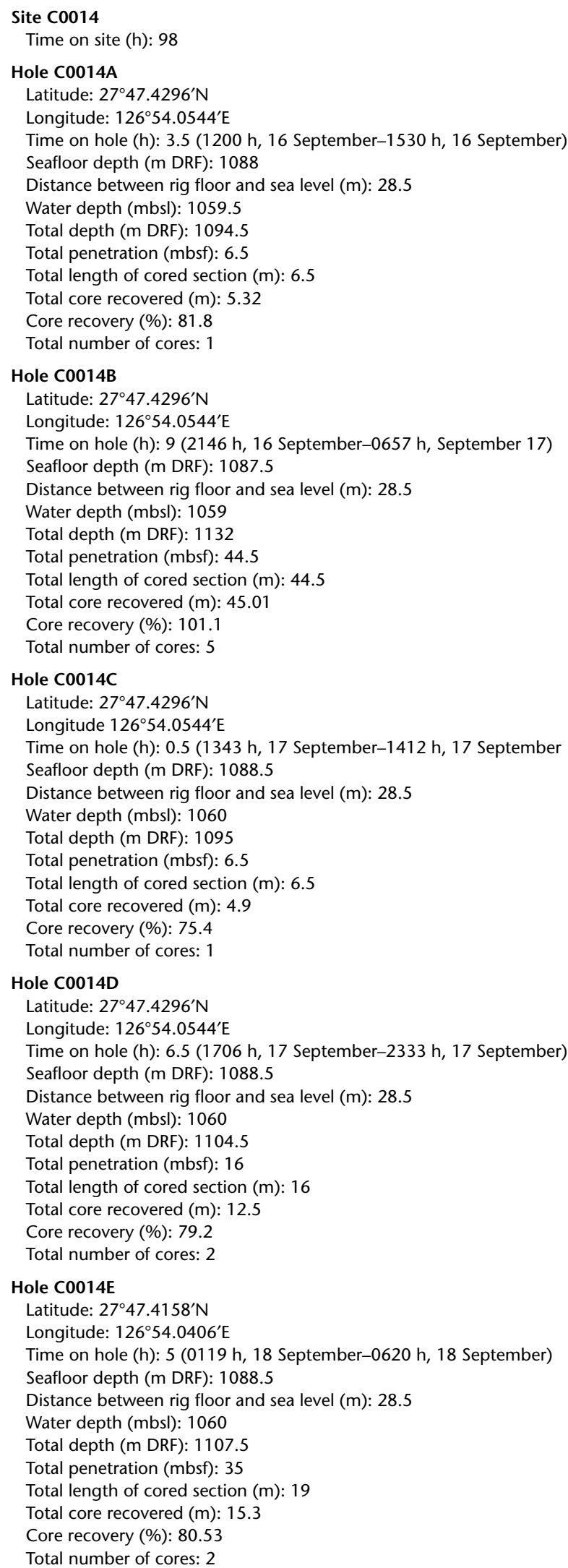


Table T1 (continued). (Continued on next page.)

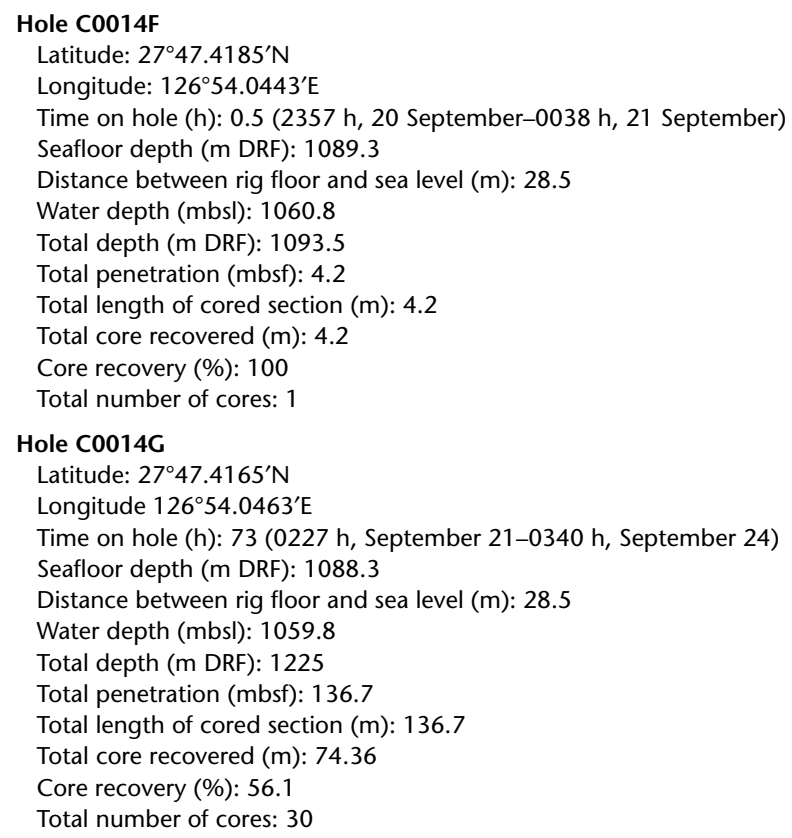

\begin{tabular}{|c|c|c|c|c|c|c|c|c|c|}
\hline \multirow[b]{2}{*}{ Core } & \multirow{2}{*}{$\begin{array}{l}\text { Date } \\
(2010)\end{array}$} & \multirow{2}{*}{$\begin{array}{l}\text { Local time } \\
\text { (h) }\end{array}$} & \multicolumn{2}{|c|}{ Depth DRF (m) } & \multicolumn{2}{|c|}{ Depth (mbsf) } & \multirow{2}{*}{$\begin{array}{l}\text { Advanced } \\
\text { (m) }\end{array}$} & \multirow{2}{*}{$\begin{array}{l}\text { Recovered } \\
\text { (m) }\end{array}$} & \multirow{2}{*}{$\begin{array}{c}\text { Recovery } \\
\text { (\%) }\end{array}$} \\
\hline & & & Top & Bottom & Top & Bottom & & & \\
\hline \multicolumn{10}{|c|}{ 331-C0014A- } \\
\hline $1 \mathrm{H}$ & $16 \mathrm{Sep}$ & 1528 & 1088 & 1094.5 & 0 & 6.5 & 6.4 & 5.52 & 81.8 \\
\hline \multicolumn{10}{|c|}{ 331-C0014B- } \\
\hline $1 \mathrm{H}$ & $16 \mathrm{Sep}$ & 2146 & 1087.5 & 1094 & 0 & 65 & 6.5 & 6.91 & 106.3 \\
\hline $2 \mathrm{H}$ & $16 \mathrm{Sep}$ & 2340 & 1094 & 1103.5 & 6.5 & 16 & 9.5 & 10 & 105.3 \\
\hline $3 \mathrm{H}$ & $17 \mathrm{Sep}$ & 0138 & 1103.5 & 1113 & 16 & 25.5 & 9.5 & 8.5 & 89.5 \\
\hline $4 \mathrm{H}$ & $17 \mathrm{Sep}$ & 0404 & 1113 & 1122.5 & 25.5 & 35 & 9.5 & 10 & 105.3 \\
\hline $5 \mathrm{H}$ & $17 \mathrm{Sep}$ & 0610 & 1122.5 & 1132 & 35 & 44.5 & 9.5 & 9.6 & 101.1 \\
\hline \multicolumn{10}{|c|}{ 331-C0014C- } \\
\hline $1 \mathrm{H}$ & 17 Sep & 1343 & 1088.5 & 1095 & 0 & 6.5 & 6.5 & 4.9 & 75.4 \\
\hline \multicolumn{10}{|c|}{ 331-C0014D- } \\
\hline $1 \mathrm{H}$ & $17 \mathrm{Sep}$ & 1706 & 1088.5 & 1095 & 0 & 6.5 & 6.5 & 5.5 & 84.6 \\
\hline $2 \mathrm{H}$ & $17 \mathrm{Sep}$ & 2201 & 1095 & 1104.5 & 6.5 & 16 & 9.5 & 7 & 73.7 \\
\hline \multicolumn{10}{|c|}{ 331-C0014E- } \\
\hline $1 \mathrm{H}$ & $18 \mathrm{Sep}$ & 0119 & 1088.5 & 1098 & 16 & 25.5 & 9.5 & 7.5 & 78.9 \\
\hline $2 \mathrm{H}$ & $18 \mathrm{Sep}$ & 0620 & 1098 & 1107.5 & 25.5 & 35 & 9.5 & 7.8 & 82.1 \\
\hline \multicolumn{10}{|c|}{ 331-C0014F- } \\
\hline $1 \mathrm{H}$ & 20 Sep & 2357 & 1089.3 & 1093.5 & 0 & 4.2 & 4.2 & 4.2 & 100 \\
\hline \multicolumn{10}{|c|}{ 331-C0014G- } \\
\hline $1 \mathrm{H}$ & $21 \mathrm{Sep}$ & 0227 & 1088.3 & 1097.5 & 0 & 9.2 & 9.2 & 9.2 & 100 \\
\hline $2 \mathrm{H}$ & $21 \mathrm{Sep}$ & 0357 & 1097.5 & 1107 & 9.2 & 18.7 & 9.5 & 9.4 & 98.9 \\
\hline $3 \mathrm{H}$ & 21 Sep & 0638 & 1107 & 1116.5 & 18.7 & 28.2 & 9.5 & 7.4 & 77.9 \\
\hline $4 \mathrm{H}$ & $21 \mathrm{Sep}$ & 0823 & 1116.5 & 1126 & 28.2 & 37.7 & 9.5 & 9.4 & 98.9 \\
\hline $5 \mathrm{H}$ & $21 \mathrm{Sep}$ & 0945 & 1126 & 1135.5 & 37.7 & 47.2 & 9.5 & 2.4 & 25.3 \\
\hline $6 \mathrm{H}$ & $21 \mathrm{Sep}$ & 1149 & 1135.5 & 1138.5 & 47.2 & 50.2 & 3 & 2.6 & 88.7 \\
\hline $7 X$ & $21 \mathrm{Sep}$ & 1510 & 1138.5 & 1141.5 & 50.2 & 53.2 & 3 & 0.21 & 7 \\
\hline $8 \mathrm{H}$ & 21 Sep & 1941 & 1141.5 & 1142.5 & 53.2 & 54.2 & 1 & 0.8 & 80 \\
\hline $9 \mathrm{X}$ & $21 \mathrm{Sep}$ & 2230 & 1142.5 & 1147 & 54.2 & 58.7 & 4.5 & 3 & 66.7 \\
\hline $10 \mathrm{H}$ & $22 \mathrm{Sep}$ & 0116 & 1147 & 1148 & 58.7 & 59.7 & 1 & 1 & 100 \\
\hline $11 X$ & $22 \mathrm{Sep}$ & 0302 & 1148 & 1152.5 & 59.7 & 64.2 & 4.5 & 0.5 & 11.1 \\
\hline $12 \mathrm{H}$ & $22 \mathrm{Sep}$ & 0516 & 1152.5 & 1155 & 64.2 & 66.7 & 2.5 & 2.2 & 88 \\
\hline $13 \mathrm{~T}$ & 22 Sep & 0745 & 1155 & 1159.5 & 66.7 & 71.2 & 4.5 & 3.5 & 77.8 \\
\hline $14 \mathrm{~T}$ & 22 Sep & 1002 & 1159.5 & 1164 & 71.2 & 75.7 & 4.5 & 2.8 & 62.2 \\
\hline $15 \mathrm{~T}$ & 22 Sep & 1241 & 1164 & 1164.2 & 75.7 & 75.9 & 0.2 & 0.2 & 100 \\
\hline $16 \mathrm{~T}$ & $22 \mathrm{Sep}$ & 1430 & 1164.2 & 1168.5 & 75.9 & 80.2 & 4.3 & 2.2 & 51.2 \\
\hline $17 \mathrm{~T}$ & $22 \mathrm{Sep}$ & 1702 & 1168.5 & 1173 & 80.2 & 84.7 & 4.5 & 3.5 & 77.8 \\
\hline $18 \mathrm{~T}$ & 22 Sep & 1954 & 1173 & 1177.5 & 84.7 & 89.2 & 4.5 & 3.6 & 80 \\
\hline 19T & 22 Sep & 2131 & 1177.5 & 1182 & 89.2 & 93.7 & 4.5 & 0.45 & 10 \\
\hline
\end{tabular}


Table T1 (continued).

\begin{tabular}{|c|c|c|c|c|c|c|c|c|c|}
\hline \multirow[b]{2}{*}{ Core } & \multirow{2}{*}{$\begin{array}{c}\text { Date } \\
(2010)\end{array}$} & \multirow{2}{*}{$\begin{array}{l}\text { Local time } \\
\text { (h) }\end{array}$} & \multicolumn{2}{|c|}{ Depth DRF (m) } & \multicolumn{2}{|c|}{ Depth (mbsf) } & \multirow{2}{*}{$\begin{array}{c}\text { Advanced } \\
(\mathrm{m})\end{array}$} & \multirow{2}{*}{$\begin{array}{l}\text { Recovered } \\
\text { (m) }\end{array}$} & \multirow{2}{*}{$\begin{array}{c}\text { Recovery } \\
\text { (\%) }\end{array}$} \\
\hline & & & Top & Bottom & Top & Bottom & & & \\
\hline $20 \mathrm{~T}$ & 22 Sep & 2312 & 1182 & 1186.5 & 93.7 & 98.2 & 4.5 & 1 & 22.2 \\
\hline $21 \mathrm{~T}$ & 23 Sep & 0207 & 1186.5 & 1188.5 & 98.2 & 100.2 & 2 & 2 & 100 \\
\hline $22 X$ & 23 Sep & 0415 & 1188.5 & 1193 & 100.2 & 104.7 & 4.5 & 0.45 & 10 \\
\hline $23 x$ & 23 Sep & 0640 & 1193 & 1197.5 & 104.7 & 109.2 & 4.5 & 0.95 & 21.1 \\
\hline $24 \mathrm{~T}$ & 23 Sep & 0823 & 1197.5 & 1202 & 109.2 & 113.7 & 4.5 & 4.2 & 93.3 \\
\hline $25 \mathrm{~T}$ & 23 Sep & 1138 & 1202 & 1206.5 & 113.7 & 118.2 & 4.5 & 0.85 & 18.9 \\
\hline $26 \mathrm{~T}$ & 23 Sep & 1417 & 1206.5 & 1211 & 118.2 & 122.7 & 4.5 & 0.05 & 1.1 \\
\hline $27 \mathrm{~T}$ & 23 Sep & 1820 & 1211 & 1215.5 & 122.7 & 127.2 & 4.5 & 0 & 0 \\
\hline $28 \mathrm{H}$ & 23 Sep & 2159 & 1215.5 & 1215.5 & 127.2 & 127.2 & 0 & 0 & 0 \\
\hline $29 \mathrm{H}$ & 24 Sep & 0035 & 1215.5 & 1215.5 & 127.2 & 127.2 & 0 & 0 & 0 \\
\hline $30 x$ & 24 Sep & 0254 & 1215.5 & 1225 & 127.2 & 136.7 & 9.5 & 0.5 & 5.3 \\
\hline
\end{tabular}

DRF = drilling depth below rig floor. $\mathrm{H}=\mathrm{HPCS}, \mathrm{X}=\mathrm{ESCS}, \mathrm{T}=\mathrm{EPCS}$.

Table T2. Lithostratigraphic units, Site C0014.

\begin{tabular}{|c|c|c|c|c|c|}
\hline $\begin{array}{l}\text { Lith. } \\
\text { unit }\end{array}$ & Description & Hole, core, section, interval (cm) & $\begin{array}{c}\text { Top depth } \\
\text { (mbsf) }\end{array}$ & $\begin{array}{l}\text { Bottom } \\
\text { depth } \\
\text { (mbsf) }\end{array}$ & $\begin{array}{l}\text { Thickness } \\
(\mathrm{m})\end{array}$ \\
\hline & & $331-$ & & & \\
\hline \multirow[t]{7}{*}{ I } & \multirow[t]{7}{*}{ Hemipelagic mud, pumice breccia } & $\mathrm{C} 0014 \mathrm{~A}-1 \mathrm{H}-1,0$, to $1 \mathrm{H}-\mathrm{CC}, 45.5$ & 0 & 5.33 & 5.33 \\
\hline & & C0014B-1H-1, 0, to $2 \mathrm{H}-6,35.0$ & 0 & 12.12 & 12.12 \\
\hline & & C0014C-1H-1, 0, to $1 \mathrm{H}-\mathrm{CC}, 19.5$ & 0 & 5.22 & 5.22 \\
\hline & & $\mathrm{C} 0014 \mathrm{D}-1 \mathrm{H}-1,0$, to $2 \mathrm{H}-3,119$ & 0 & 10.45 & 10.45 \\
\hline & & $\mathrm{C} 0014 \mathrm{E}-1 \mathrm{H}-0,0$, to $1 \mathrm{H}-2,140.5$ & 16 & 17.54 & 1.54 \\
\hline & & $\mathrm{C} 0014 \mathrm{~F}-1 \mathrm{H}-1,0$, to $1 \mathrm{H}-5,99$ & 0 & 4.2 & 4.2 \\
\hline & & C0014G-1H-1, 0, to $2 \mathrm{H}-5,117$ & 0 & 15.95 & 15.95 \\
\hline \multirow[t]{4}{*}{ II } & \multirow{4}{*}{$\begin{array}{l}\text { Hydrothermally altered mud, mud, and sand } \\
\text { with detrital hydrothermal component }\end{array}$} & C0014B $2 \mathrm{H}-6,35.0$, to $5 \mathrm{H}-\mathrm{CC}, 22.5$ & 12.12 & 45.28 & 33.16 \\
\hline & & C0014D-2H-3, 119 , to $2 \mathrm{H}-\mathrm{CC}, 35.0$ & 10.45 & 15.42 & 5.41 \\
\hline & & $\mathrm{C} 0014 \mathrm{E}-1 \mathrm{H}-3,0$, to $2 \mathrm{H}-6,62$ & 17.5 & 30.6 & 13.1 \\
\hline & & $\mathrm{C} 0014 \mathrm{G}-2 \mathrm{H}-6,0$, to $4 \mathrm{H}-1,37.5$ & 16.2 & 28.57 & 12.37 \\
\hline \multirow[t]{2}{*}{ III } & \multirow[b]{2}{*}{$\begin{array}{l}\text { Silicified volcanic sediments (either matrix } \\
\text { silicified or clasts and matrix silicifed), } \\
\text { hydrothermally altered mud, mud, and sand } \\
\text { with detrital hydrothermal component, other } \\
\text { volcaniclastic sedimentary rock }\end{array}$} & C0014E-2H-6, 62 , to $2 \mathrm{H}-\mathrm{CC}, 17.5$ & 30.6 & 34.78 & 4.18 \\
\hline & & C0014G-4H-1, 37.5, to $30 \mathrm{X}-\mathrm{CC}, 19.5$ & 28.57 & 127.87 & 99.3 \\
\hline
\end{tabular}


Table T3. Grain size parameters of sediments from Holes C0014A and C0014B.

\begin{tabular}{|c|c|c|c|c|c|c|c|c|}
\hline $\begin{array}{l}\text { Hole, core, section, } \\
\text { interval }(\mathrm{cm})\end{array}$ & $\begin{array}{l}\text { Depth } \\
\text { (mbsf) }\end{array}$ & $\begin{array}{l}\text { Mean } \\
\text { grain } \\
\text { size } \\
(\Phi)\end{array}$ & $\begin{array}{l}\text { SD } \\
(\Phi)\end{array}$ & Skewness & Kurtosis & $\begin{array}{l}\text { Clay } \\
(\%)\end{array}$ & $\begin{array}{l}\text { Silt } \\
(\%)\end{array}$ & $\begin{array}{l}\text { Sand } \\
(\%)\end{array}$ \\
\hline \multicolumn{9}{|l|}{$331-$} \\
\hline C0014A-1H-1, 21-22 & 0.215 & 6.84 & 1.82 & -0.49 & 2.23 & 14.94 & 75.01 & 10.05 \\
\hline C0014A-1H-2, 21-22 & 0.925 & 7.67 & 1.67 & 1.01 & 2.07 & 26.68 & 73.32 & 0.00 \\
\hline C0014A-1H-2, 80-81 & 1.515 & 7.73 & 1.63 & 0.94 & 2.03 & 26.79 & 73.21 & 0.00 \\
\hline C0014A-1H-3, 40-41 & 2.305 & 7.64 & 1.74 & -0.49 & 2.22 & 26.55 & 71.30 & 2.15 \\
\hline C0014A-1H-4, 35-36 & 3.155 & 7.83 & 1.59 & 0.90 & 2.01 & 27.97 & 72.03 & 0.00 \\
\hline C0014A-1H-4, 140-141 & 4.205 & 7.80 & 1.61 & 0.69 & 2.06 & 27.38 & 72.28 & 0.34 \\
\hline C0014A-1H-5, 12-13 & 4.395 & 4.14 & 2.72 & 3.25 & 3.68 & 12.22 & 36.02 & 51.76 \\
\hline C0014A-1H-5, 55-56 & 4.825 & 4.02 & 2.60 & 3.11 & 3.56 & 9.57 & 36.30 & 54.13 \\
\hline C0014A-1H-CC, 10-11 & 4.995 & 3.35 & 2.36 & 3.05 & 3.58 & 6.11 & 27.56 & 66.33 \\
\hline C0014B-1H-1, 70-71 & 0.705 & 7.60 & 1.69 & 1.02 & 2.15 & 24.53 & 74.52 & 0.95 \\
\hline C0014B-1H-3, 50-51 & 3.315 & 7.72 & 1.66 & 0.55 & 2.11 & 26.81 & 72.23 & 0.96 \\
\hline C0014B-1H-5, 35-36 & 5.995 & 7.72 & 1.68 & 0.79 & 2.12 & 27.01 & 72.73 & 0.26 \\
\hline C0014B-2H-1, 60-61 & 7.105 & 7.78 & 1.60 & 0.94 & 2.01 & 27.56 & 72.44 & 0.00 \\
\hline C0014B-2H-2, 31-32 & 8.185 & 7.76 & 1.64 & 1.04 & 2.06 & 27.64 & 72.36 & 0.00 \\
\hline C0014B-2H-3, 90-91 & 9.475 & 5.89 & 2.24 & 2.02 & 2.83 & 13.89 & 59.56 & 26.55 \\
\hline C0014B-2H-5, 50-51 & 11.235 & 7.53 & 1.67 & 0.62 & 2.12 & 23.02 & 75.67 & 1.31 \\
\hline C0014B-3H-1, 18-19 & 16.185 & 4.56 & 2.03 & 2.32 & 2.86 & 4.04 & 55.68 & 40.28 \\
\hline C0014B-3H-2, 18-19 & 17.025 & 2.77 & 2.00 & 2.74 & 3.35 & 1.97 & 23.99 & 74.04 \\
\hline C0014B-3H-3, 40-41 & 18.015 & 3.05 & 2.04 & 2.62 & 3.10 & 1.75 & 36.36 & 61.89 \\
\hline C0014B-3H-4, 50-51 & 19.125 & 7.41 & 1.66 & 1.01 & 2.09 & 22.01 & 76.77 & 1.22 \\
\hline C0014B-3H-5, 60-61 & 20.46 & 3.63 & 1.83 & 2.28 & 2.79 & 1.22 & 47.45 & 51.33 \\
\hline C0014B-3H-7, 40-41 & 22.28 & 3.68 & 2.24 & 2.77 & 3.23 & 3.71 & 43.42 & 52.87 \\
\hline C0014B-3H-8, 50-51 & 23.57 & 3.64 & 2.28 & 2.82 & 3.28 & 4.28 & 42.85 & 52.86 \\
\hline C0014B-3H-10, 25-26 & 25.315 & 5.49 & 2.02 & 1.95 & 2.70 & 7.66 & 66.47 & 25.87 \\
\hline C0014B-3H-11, 50-51 & 26.13 & 5.83 & 1.99 & 1.63 & 2.73 & 9.57 & 65.36 & 25.07 \\
\hline C0014B-4H-1, 30-31 & 25.805 & 2.64 & 3.11 & 3.04 & 3.62 & 2.78 & 28.72 & 68.50 \\
\hline C0014B-4H-2, 72-73 & 26.79 & 2.89 & 0.02 & 3.20 & 3.73 & 3.79 & 33.26 & 62.95 \\
\hline C0014B-4H-3, 85-86 & 28.325 & 2.90 & 0.02 & 3.21 & 3.75 & 3.96 & 31.71 & 64.33 \\
\hline C0014B-4H-4, 105-106 & 29.935 & 4.45 & 0.02 & 2.75 & 3.19 & 7.50 & 50.00 & 42.50 \\
\hline C0014B-4H-7, 30-31 & 32.235 & 7.09 & 0.03 & 0.85 & 2.54 & 18.71 & 73.14 & 8.16 \\
\hline C0014B-4H-8, 45-46 & 33.795 & 2.83 & 0.02 & 3.31 & 3.86 & 4.63 & 31.49 & 63.88 \\
\hline C0014B-5H-11, 30-31 & 40.005 & 5.02 & 2.13 & 2.30 & 2.86 & 6.61 & 58.92 & 34.47 \\
\hline C0014B-5H-12, 35-36 & 40.94 & 5.43 & 2.12 & 2.34 & 3.03 & 8.30 & 64.73 & 26.97 \\
\hline C0014B-5H-13, 80-81 & 42.29 & 3.39 & 2.62 & 3.32 & 3.85 & 7.65 & 31.12 & 61.24 \\
\hline C0014B-5H-15, 20-21 & 44.065 & 3.31 & 2.75 & 3.48 & 4.02 & 8.52 & 26.79 & 64.68 \\
\hline
\end{tabular}

$\mathrm{SD}=$ standard deviation. 
Table T4. Dry mass and stereo light microscopic observations of micropaleontology samples, Site C0014.

\begin{tabular}{|c|c|c|c|c|c|}
\hline \multirow{2}{*}{$\begin{array}{c}\text { Core, section, interval } \\
(\mathrm{cm})\end{array}$} & \multirow{2}{*}{$\begin{array}{l}\text { Depth } \\
\text { (mbsf) }\end{array}$} & \multicolumn{3}{|c|}{ Mass $(\mathrm{g})$} & \multirow[b]{2}{*}{ Comments } \\
\hline & & $>1 \mathrm{~mm}$ & $150 \mu \mathrm{m}$ to $1 \mathrm{~mm}$ & $63-150 \mu \mathrm{m}$ & \\
\hline \multicolumn{6}{|l|}{ 331-C0014A- } \\
\hline $1 \mathrm{H}-1,1-2$ & 0.01 & & & & Microfossils present \\
\hline $1 \mathrm{H}-\mathrm{CC}, 44.5-45.5$ & 5.3 & 12.05 & 1.07 & 0.46 & Pumice clasts and fragments \\
\hline \multicolumn{6}{|l|}{ 331-C0014B- } \\
\hline $1 \mathrm{H}-1,5-7$ & 0.1 & & & & Microfossils present \\
\hline $2 \mathrm{H}-\mathrm{CC}, 34.5-35.5$ & 17.1 & 0.01 & 1.43 & 1.68 & Pumice with minor foraminifer content \\
\hline $3 \mathrm{H}-\mathrm{CC}, 33-34$ & 27.5 & 2 & 2.92 & 1.15 & White clay with euhedral pyrite, anhydrite, minor pyrite sphalerite \\
\hline $4 \mathrm{H}-\mathrm{CC}, 27.5-28.5$ & 35.7 & 1.6 & 6.68 & 1.54 & White clay with euhedral pyrite anhydrite \\
\hline $5 \mathrm{H}-\mathrm{CC}, 21.5-22.5$ & 45.3 & 5.59 & 2.01 & 0.99 & White clay with euhedral pyrite anhydrite, minor pyrite \\
\hline \multicolumn{6}{|l|}{ 331-C0014C- } \\
\hline $1 \mathrm{H}-\mathrm{CC}, 19.5-20.5$ & 5.2 & 3.62 & 2.36 & 2.35 & Pumice clasts and fragments \\
\hline \multicolumn{6}{|l|}{ 331-C0014E- } \\
\hline $1 \mathrm{H}-\mathrm{CC}, 25-26$ & 25.1 & 0.03 & 0.88 & 0.44 & Pumice euhedral pyrite, white clay euhedral pyrite, minor framboidal pyrite \\
\hline $2 \mathrm{H}-\mathrm{CC}, 17.5-18.5$ & 34.8 & 3.29 & 1.81 & 0.62 & White clay, minor anhydrite \\
\hline \multicolumn{6}{|l|}{ 331-C0014F- } \\
\hline $1 \mathrm{H}-3,82-83$ & 2.0 & & & & Microfossils present \\
\hline $1 \mathrm{H}-5,99-100$ & 4.2 & 12.76 & 0.62 & 0.22 & Pumice clasts and fragments \\
\hline \multicolumn{6}{|l|}{ 331-C0014G- } \\
\hline $1 \mathrm{H}-\mathrm{CC}, 17.5-18.5$ & 9.5 & 3.36 & 2 & 0.85 & Pumice clasts and fragments \\
\hline $2 \mathrm{H}-\mathrm{CC}, 32-33$ & 19.0 & NM & 2.28 & 2.24 & Weathered pumice, minor pyrite, large $<63 \mu \mathrm{m}$ fraction \\
\hline $3 \mathrm{H}-\mathrm{CC}, 78.5-79.5$ & 29.0 & NM & 0.23 & 0.69 & Weathered pumice, minor pyrite, large $<63 \mu \mathrm{m}$ fraction \\
\hline $4 \mathrm{H}-\mathrm{CC}, 22.5-23.5$ & 37.7 & 7.68 & 3.05 & 0.57 & White clay with euhedral pyrite \\
\hline $5 \mathrm{H}-\mathrm{CC}, 5-6$ & 40.0 & 33.92 & 0.35 & 0.1 & Weathered clasts in matrix, white clay with euhedral pyrite, minor sphalerite \\
\hline $6 \mathrm{H}-\mathrm{CC}, 99-100$ & 53.8 & 10.96 & 3.71 & 1.34 & White clay with euhedral pyrite \\
\hline 7X-CC, 30-31 & 50.5 & 16.99 & 4.71 & 4.2 & White clay with euhedral pyrite anhydrite \\
\hline $17 \mathrm{~T}-\mathrm{CC}, 8.5-9.5$ & 83.7 & 15.71 & 1.08 & 0.21 & Hardened gray clay clasts and fragments \\
\hline $18 \mathrm{~T}-\mathrm{CC}, 30.5-31.5$ & 88.3 & 11.5 & 5.43 & 2.86 & White clay anhydrite, minor pyrite and sphalerite \\
\hline $19 \mathrm{~T}-\mathrm{CC}, 25.5-26.5$ & 89.6 & 6.38 & 6.52 & 3.24 & Anhydrite white clay, minor pyrite and sphalerite \\
\hline 20T-CC, 39.5-40.5 & 94.7 & 13.32 & 4.07 & 1.48 & Anhydrite white clay \\
\hline $21 \mathrm{H}-\mathrm{CC}, 0-1$ & 100.1 & 22.99 & 3.5 & 0.74 & White clay with euhedral pyrite anhydrite, sphalerite flakes \\
\hline $22 \mathrm{X}-\mathrm{CC}, 15-16$ & 100.7 & 21.92 & 2.52 & 1.07 & White clay with euhedral pyrite anhydrite \\
\hline $23 X-C C, 14-15$ & 105.7 & 11.38 & 5.21 & 1.62 & White clay with euhedral pyrite gray clay \\
\hline $24 \mathrm{~T}-\mathrm{CC}, 56-57$ & 113.4 & 18.23 & 7.09 & 3.66 & White clay \\
\hline 25T-CC, 19.5-20.5 & 114.5 & 11.17 & 4.86 & 2.73 & White clay anhydrite \\
\hline $26 \mathrm{~T}-\mathrm{CC}, 1-2$ & 118.2 & 5 & 0.41 & $\mathrm{BD}$ & Anhydrite sphalerite pyrite \\
\hline 27 & & - & - & - & No core \\
\hline 28 & & - & - & - & No core \\
\hline 29 & & - & - & - & No core \\
\hline $30 X-1,19.5-20.5$ & 127.9 & 13.07 & 4.16 & 3 & White clay anhydrite pyrite \\
\hline
\end{tabular}

$\mathrm{NM}=$ not measured $\mathrm{BD}=$ below detection. $-=$ no data. 
Table T5. Foraminifers: micropaleontological observations, Site C0014.

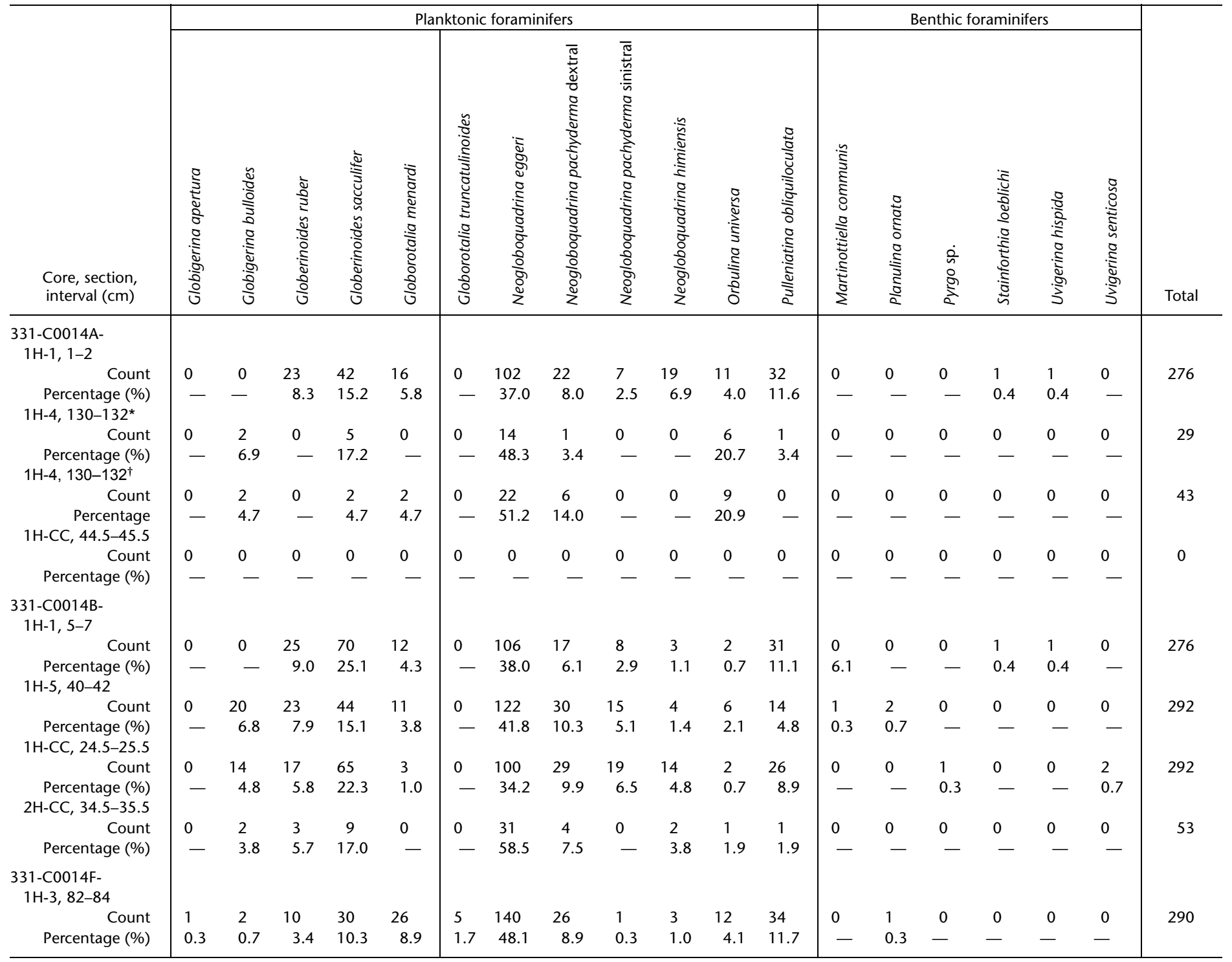

* $=$ carbonate tests, $\dagger=$ pyritized tests. $-=$ No data 
Table T6. Coccolithophorids: micropaleontological observations, Site C0014.

\begin{tabular}{|c|c|c|c|c|c|c|c|c|c|c|c|c|c|c|}
\hline $\begin{array}{l}\text { Core, section, } \\
\text { interval }(\mathrm{cm})\end{array}$ & 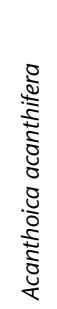 & 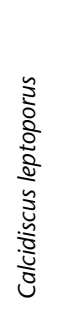 & 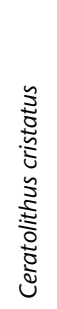 & 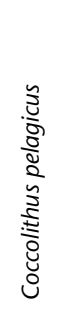 & 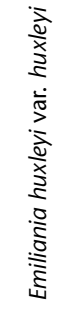 & 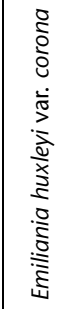 & 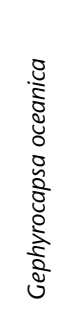 & 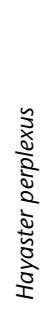 & 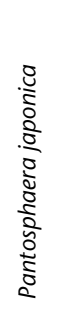 & 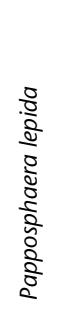 & 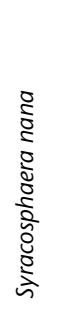 & 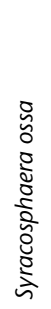 & 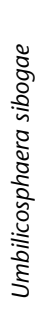 & Total \\
\hline \multicolumn{15}{|l|}{$\begin{array}{c}331-\mathrm{C} 0014 \mathrm{~A}- \\
1 \mathrm{H}-1,1-2\end{array}$} \\
\hline Count & 1 & 5 & 2 & 5 & 18 & 9 & 22 & 1 & 0 & 2 & 3 & 1 & 0 & 69 \\
\hline Percentage (\%) & 1.4 & 7.2 & 2.9 & 7.2 & 26.1 & 13.0 & 31.9 & 1.4 & - & 2.9 & 4.3 & 1.4 & - & \\
\hline \multicolumn{15}{|l|}{$\begin{array}{c}331-\mathrm{C} 0014 \mathrm{~B}- \\
1 \mathrm{H}-\mathrm{CC}, 0\end{array}$} \\
\hline Count & 0 & 0 & 3 & 1 & 21 & 2 & 17 & 0 & 2 & 0 & 0 & 0 & 1 & 47 \\
\hline Percentage (\%) & - & - & 6.4 & 2.1 & 44.7 & 4.3 & 36.2 & - & 4.3 & - & - & - & 2.1 & \\
\hline
\end{tabular}

$-=$ no data. 
Table T7. Interpreted results of X-ray diffraction (XRD) analyses of samples, Site C0014. (Continued on next three pages.)

\begin{tabular}{|c|c|c|c|c|}
\hline $\begin{array}{l}\text { Sample } \\
\text { number }\end{array}$ & $\begin{array}{l}\text { Core, section, } \\
\text { interval }(\mathrm{cm})\end{array}$ & Lithology & Subsampled for & Result \\
\hline & 331-C0014A- & & & \\
\hline 30301 & $1 \mathrm{H}-1,30-32$ & Very soft, brown silty clay & Routine chemistry & Quartz, calcite, muscovite, anorthite, Mg chlorite \\
\hline 30306 & $1 \mathrm{H}-3,30-32$ & Soft brown silty clay & Routine chemistry & Quartz, muscovite, Mg chlorite, albite/microcline, orthopyroxene ??? \\
\hline 30310 & $1 \mathrm{H}-5,30-32$ & Clast-supported pumiceous gravel & Routine chemistry & Quartz, muscovite, pyrite, albite, lithium plagioclase ??? \\
\hline \multirow[t]{2}{*}{30317} & $1 \mathrm{H}-\mathrm{CC}, 20-22$ & Clast-supported pomaceous gravel & Routine chemistry & Quartz and opal, pyrite, anorthite \\
\hline & 331-C0014B- & & & \\
\hline 30540 & $1 \mathrm{H}-1,19-21$ & Brown mud & Routine chemistry & Calcite, quartz, anorthite, muscovite, Mg chlorite \\
\hline 30542 & $1 \mathrm{H}-3,60-62$ & Brown mud & Routine chemistry & Quartz, calcite, muscovite, Mg chlorite, anorthite, pyrite \\
\hline 30544 & $1 \mathrm{H}-5,52-54$ & Brown mud & Routine chemistry & Quartz, calcite, muscovite, Mg chlorite, anorthite, pyrite \\
\hline 30609 & $2 \mathrm{H}-1,70-72$ & Indurated dark gray clay & Routine chemistry & Quartz, muscovite, Mg chlorite, anorthite, pyrite \\
\hline 30614 & $2 \mathrm{H}-2,54-56$ & Pumiceous grit & Routine chemistry & Less crystalline quartz, muscovite, $\mathrm{Mg}$ chlorite, anorthite, pyrite \\
\hline 30618 & $2 \mathrm{H}-3,117-119$ & Pumiceous gravel & Routine chemistry & Less crystalline quartz, muscovite, $\mathrm{Mg}$ chlorite, anorthite, pyrite \\
\hline 30661 & $2 \mathrm{H}-4,10-12$ & Pumiceous gravel/grit & Routine chemistry & Less crystalline quartz, muscovite, Mg chlorite, anorthite, pyrite \\
\hline 30669 & $2 \mathrm{H}-4,50-51$ & Altered grayish-blue clay & XRD only & Less crystalline pyrite, quartz, kaolinite \\
\hline 30671 & $2 \mathrm{H}-5,88-89$ & Dark gray clay & XRD only & Quartz, kaolinite, pyrite, barite \\
\hline 30621 & $2 \mathrm{H}-6,11-13$ & Mottled dark clay & Routine chemistry & Barite, kaolinite, muscovite, quartz, pyrite \\
\hline 30626 & $2 \mathrm{H}-6,57-59$ & Pale bluish-gray clay & Routine chemistry & Kaolinite, pyrite, covellite ??? \\
\hline 30688 & $2 \mathrm{H}-7,12-13$ & Bluish clay with white clay spots & XRD only & Kaolinite, pyrite \\
\hline 30709 & $2 \mathrm{H}-9,56-58$ & Dark gray clay & Routine chemistry & Quartz, pyrite, muscovite \\
\hline 30712 & $2 \mathrm{H}-11,2-4$ & Gray clay with white spots & Routine chemistry & Kaolinite, quartz, pyrite, sphalerite/wurtzite \\
\hline 30715 & $2 \mathrm{H}-12,55-57.5$ & Dark gray clay & Routine chemistry & Pyrite, noncrystalline layer silicate \\
\hline 30781 & $3 \mathrm{H}-1,26-27$ & Gray clay with white spots & XRD only & Pyrite, kaolinite, muscovite (breaking down)/montmorillonite \\
\hline 30782 & $3 \mathrm{H}-1,48-50$ & Pale bluish-gray clay & Routine chemistry & Quartz, muscovite, pyrite \\
\hline 30785 & $3 \mathrm{H}-2,24-26$ & Pale bluish-gray clay & Routine chemistry & Muscovite, quartz, pyrite \\
\hline 30847 & $3 \mathrm{H}-3,44-46$ & Gray clay/grit possible; ash alteration & Routine chemistry & Pyrite, muscovite/illite/montmorillonite, quartz \\
\hline 30850 & $3 \mathrm{H}-4,54-56$ & Gray clay & Routine chemistry & Quartz, pyrite, muscovite \\
\hline 30853 & $3 \mathrm{H}-5,80-82$ & White/Gray clay & Routine chemistry & Pyrite, quartz, muscovite/illite/montmorillonite \\
\hline 30857 & $3 \mathrm{H}-8,95-97$ & White/Gray clay & Routine chemistry & Pyrite, quartz, muscovite/illite/montmorillonite \\
\hline 30859 & $3 \mathrm{H}-10,43 \mathrm{H}-45$ & Gray/Bluish clay & Routine chemistry & Pyrite, muscovite/montmorillonite \\
\hline 30862 & $3 \mathrm{H}-12,2-3 \mathrm{H}-$ & Altered pumice clast & XRD only & Quartz, pyrite, muscovite/illite/montmorillonite \\
\hline 30981 & $4 \mathrm{H}-1,42-44$ & Gray/White hydrothermal clay & Routine chemistry & Pyrite, Mg chlorite, quartz \\
\hline 30986 & $4 \mathrm{H}-2,89-91$ & Dark gray/brown hydrothermal clay with sulfides & Routine chemistry & Pyrite, $\mathrm{Mg}$ chlorite, quartz \\
\hline 30991 & $4 \mathrm{H}-3,12-14$ & White/Gray hydrothermal clay & Routine chemistry & Pyrite, quartz, Mg chlorite, muscovite \\
\hline 31012 & $4 \mathrm{H}-3,132-134$ & Gray clast & Identify clast composition; XRD only & Pyrite, Mg chlorite, quartz, muscovite \\
\hline 30994 & $4 \mathrm{H}-4,58-60$ & Dark gray/brown hydrothermal clay & Routine chemistry & Mg chlorite, pyrite, quartz, covellite ??? \\
\hline 31018 & $4 \mathrm{H}-4,90-92$ & Dark brown clast & Identify clast composition; XRD only & Mg chlorite, pyrite, sphalerite/wurtzite \\
\hline 30999 & $4 \mathrm{H}-6,13-15$ & White/Gray hydrothermal clay & Routine chemistry & Quartz, pyrite, Mg chlorite \\
\hline 31002 & $4 \mathrm{H}-7,39-41$ & Dark gray/brown hydrothermal clay & Routine chemistry & Mg chlorite, pyrite, muscovite \\
\hline 31006 & $4 \mathrm{H}-8,18-20$ & Gray/White hydrothermal clay & Routine chemistry & Mg chlorite, pyrite \\
\hline 31010 & $4 \mathrm{H}-9,40-42$ & Gray/White hydrothermal clay & Routine chemistry & Mg chlorite, pyrite \\
\hline 31498 & $5 \mathrm{H}-3,21.5-23.5$ & Pale gray clay from pseudoclastic mottling & Routine chemistry & Mg chlorite, pyrite, copper sulfide ???, antigorite?? \\
\hline 31510 & $5 \mathrm{H}-4,30-32$ & Mottled clay bulk sample & Routine chemistry & Mg chlorite, pyrite, copper sulfide??? \\
\hline 31501 & $5 \mathrm{H}-5,12-14$ & Dark gray clay from pseudoclastic mottling & Routine chemistry & Pyrite, Mg chlorite, quartz \\
\hline 31502 & $5 \mathrm{H}-6,24-26$ & Very pale gray clay & Routine chemistry & Mg chlorite, pyrite, muscovite \\
\hline 31120 & $5 \mathrm{H}-11,80-82$ & White/Gray clay & Routine chemistry & Mg chlorite, pyrite, quartz \\
\hline 31127 & $5 \mathrm{H}-12,80-82$ & White/Gray clay & Routine chemistry & Mg chlorite, pyrite, muscovite \\
\hline 31124 & $5 \mathrm{H}-13,104-107$ & Silica cemented volcaniclastic clast & Routine chemistry & Quartz, pyrite, muscovite \\
\hline 31131 & $5 \mathrm{H}-15,27-29$ & White/Gray clay with pumice fragments & Routine chemistry & Quartz, pyrite, muscovite \\
\hline
\end{tabular}


Table T7 (continued). (Continued on next page.)

\begin{tabular}{|c|c|c|c|c|}
\hline $\begin{array}{l}\text { Sample } \\
\text { number }\end{array}$ & $\begin{array}{l}\text { Core, section, } \\
\text { interval }(\mathrm{cm})\end{array}$ & Lithology & Subsampled for & Result \\
\hline & \multicolumn{4}{|l|}{ 331-C0014C- } \\
\hline 31222 & $1 \mathrm{H}-1,12-14$ & Pumiceous gravel/grit & Routine chemistry & Quartz, anorthite, muscovite, kaolinite \\
\hline 31229 & $1 \mathrm{H}-4,29-31$ & Pumiceous gravel/grit & Routine chemistry & Poorly crystalline quartz/opal, covellite, pyrite \\
\hline 31232 & $1 \mathrm{H}-4,97-99$ & Green grit and pumice & Routine chemistry & Poorly crystalline quartz/opal, pyrite, corundum \\
\hline 31236 & $1 \mathrm{H}-6,37.5-39.5$ & Green material and pumice & Routine chemistry & Poorly crystalline quartz/opal, covellite \\
\hline 31257 & \multicolumn{4}{|l|}{ 331-C0014D- } \\
\hline 31260 & $1 \mathrm{H}-1,98-100$ & Silty mud & Routine chemistry & Quartz, anorthite, muscovite, pyrite, Mg chlorite, cristobalite ??? \\
\hline 31264 & $1 \mathrm{H}-2,108-110$ & Pumice clasts with grit & Routine chemistry & Poorly crystalline quartz/opal, pyrite \\
\hline 31278 & $1 \mathrm{H}-3,80-82$ & Greenish clayey pumiceous grit & Routine chemistry & Quartz, anorthite, muscovite, kaolinite \\
\hline 31282 & $1 \mathrm{H}-4,80-82$ & Gray clast-supported pumiceous grit & Routine chemistry & Poorly crystalline quartz/opal, covellite, pyrite \\
\hline 31338 & $2 \mathrm{H}-1,30-32$ & Black pumice clast & Routine chemistry & Poorly crystalline quartz/opal, pyrite, sphalerite/wurtzite \\
\hline 31342 & $2 \mathrm{H}-2,30-32$ & Altered pumice clast, light gray & Routine chemistry & Opal, pyrite, halite \\
\hline 31346 & $2 \mathrm{H}-3,37-39$ & Dark gray hydrothermal mud with pumice & Routine chemistry & Pyrite, halite, muscovite, quartz, sulfur??? \\
\hline 31348 & $2 \mathrm{H}-3,115-117$ & Light gray clay/mud before transition "hydrothermal" & Routine chemistry & Pyrite, halite, quartz, sulfur ???, muscovite/illite/montmorillonite \\
\hline 31353 & $2 \mathrm{H}-3,132.5-134.5$ & Dark gray clay after transition "hydrothermal" & Routine chemistry & Quartz, pyrite, muscovite, anorthite \\
\hline 31354 & $2 \mathrm{H}-4,98-99$ & Dark sulfide deposit & XRD only & Pyrite, quartz, kaolinite \\
\hline 31355 & $2 \mathrm{H}-5,20-22$ & Light brown material on surface "hydrothermal" & Routine chemistry & Kaolinite, pyrite, quartz, woodhouseite, anorthite \\
\hline 31359 & $2 \mathrm{H}-6,60-62$ & Dark gray clay/mud "hydrothermal" & Routine chemistry & Quartz, pyrite, muscovite \\
\hline 31362 & $2 \mathrm{H}-7,50-52$ & Black/gray clay "hydrothermal" & Routine chemistry & Pyrite, quartz, muscovite, marcasite?? \\
\hline 31365 & $2 \mathrm{H}-8,30-32$ & Gray clay "hydrothermal" & Routine chemistry & Quartz, pyrite, muscovite \\
\hline \multirow[t]{2}{*}{31367} & $2 \mathrm{H}-\mathrm{CC}, 5-6$ & Gray hydrothermal clay & XRD only & Pyrite, quartz, muscovite/illite/montmorillonite, covellite ??? \\
\hline & \multicolumn{4}{|l|}{ 331-C0014E- } \\
\hline 31437 & $1 \mathrm{H}-2,40-42$ & Pumiceous grit & Routine chemistry & Quartz, anorthite, cristobalite, pyrite, muscovite/illite/montmorillonite \\
\hline 31439 & $1 \mathrm{H}-3,134-136$ & Gray clay_hydrothermal & Routine chemistry & Quartz, pyrite, muscovite \\
\hline 31441 & $1 \mathrm{H}-4,125-127$ & Gray and white clay_mottled, hydrothermal & Routine chemistry & Pyrite, quartz, anorthite, muscovite/illite/montmorillonite \\
\hline 31443 & $1 \mathrm{H}-5,80-82$ & Gray and white clay_mottled, hydrothermal & Routine chemistry & Quartz, pyrite, muscovite/illite/montmorillonite, sphalerite/wurtzite \\
\hline 31445 & $1 \mathrm{H}-6,30-32$ & Gray clay_hydrothermal & Routine chemistry & Quartz, muscovite, pyrite \\
\hline 31447 & $1 \mathrm{H}-7,75-77$ & Gray and white clay_mottled, hydrothermal & Routine chemistry & Quartz, pyrite, muscovite/illite/montmorillonite \\
\hline 31449 & $1 \mathrm{H}-8,40-42$ & Gray and white clay_mottled, hydrothermal & Routine chemistry & Quartz, pyrite, copper sulfide, muscovite/illite/montmorillonite \\
\hline 31451 & $1 \mathrm{H}-9,20-22$ & Gray clay_hydrothermal & Routine chemistry & Quartz, muscovite, pyrite, sphalerite/wurtzite \\
\hline 31468 & $2 \mathrm{H}-1,92-94$ & Gray-white mottled clay & Routine chemistry & Quartz, pyrite, dolomite, Mg chlorite, muscovite (minor) \\
\hline 31470 & $2 \mathrm{H}-4,85-87$ & Dark brownish-gray pyritic clay & Routine chemistry & Pyrite, Mg chlorite, dolomite, halite \\
\hline 31473 & $2 \mathrm{H}-5,123-125$ & Pseudoclastic textured mottled clay & Routine chemistry & Mg chlorite, pyrite, halite, muscovite \\
\hline 31474 & $2 \mathrm{H}-6,107-109$ & Gritty gray-white mottled clay & Routine chemistry & Quartz, pyrite, muscovite \\
\hline 31476 & $2 \mathrm{H}-7,44-46$ & Gray-white mottled clay & Routine chemistry & Pyrite, Mg chlorite, quartz, halite, kaolinite, Ag sulfide ??? \\
\hline \multirow[t]{2}{*}{31478} & $2 \mathrm{H}-8,110-112$ & Gray-white mottled clay & Routine chemistry & Pyrite, Mg chlorite, kaolinite (minor) \\
\hline & \multicolumn{4}{|l|}{ 331-C0014F- } \\
\hline 32735 & $1 \mathrm{H}-1,5-7$ & Oxidized silty clay & Routine chemistry & Calcite, quartz, halite, muscovite, anorthite, chlorite \\
\hline 32737 & $1 \mathrm{H}-2,80-82$ & Olive-green reduced clay & Routine chemistry & Quartz, chlorite, muscovite, calcite, anorthite \\
\hline 32739 & $1 \mathrm{H}-3,82-84$ & Foraminiferal silt & Paleontology & \\
\hline 32740 & $1 \mathrm{H}-4,64-66$ & Gritty olive-green clay & Routine chemistry & Quartz, muscovite, chlorite, cristobalite \\
\hline \multirow[t]{2}{*}{32742} & $1 \mathrm{H}-5,78-80$ & Pumiceous gravel & Routine chemistry & Noncrystalline $\mathrm{SiO}_{2}$, quartz, halite, muscovite (trace) \\
\hline & \multicolumn{4}{|l|}{ 331-C0014G- } \\
\hline 32825 & $1 \mathrm{H}-1,0-2$ & Oxidized foraminiferal sand & Routine chemistry & Quartz, muscovite, calcite, chlorite, halite, cristobalite, pyrite (trace) \\
\hline 32823 & $1 \mathrm{H}-2,20-22$ & Olive-green reduced clay & Routine chemistry & Quartz, muscovite, calcite, chlorite, halite, pyrite, cristobalite \\
\hline 32816 & $1 \mathrm{H}-3,120-122$ & Olive-green reduced clay & Routine chemistry & Quartz, muscovite, pyrite, cristobalite, chlorite \\
\hline 32820 & $1 \mathrm{H}-5,10-12$ & Gray hydrothermal clay & Routine chemistry & Quartz, muscovite, anorthite, pyrite, Mg chlorite (trace) \\
\hline 32813 & $1 \mathrm{H}-6,36-38$ & Tube pumice & Routine chemistry & Noncrystalline $\mathrm{SiO}_{2}$, halite \\
\hline
\end{tabular}


Table T7 (continued). (Continued on next page.)

\begin{tabular}{|c|c|c|c|c|}
\hline $\begin{array}{l}\text { Sample } \\
\text { number }\end{array}$ & $\begin{array}{l}\text { Core, section, } \\
\text { interval }(\mathrm{cm})\end{array}$ & Lithology & Subsampled for & Result \\
\hline 32809 & $1 \mathrm{H}-7,48-50$ & Sugary, partially devitrified pumice & Routine chemistry & Noncrystalline $\mathrm{SiO}_{2}$, halite, quartz \\
\hline 32867 & $2 \mathrm{H}-1,42-44$ & Pumice clast & Routine chemistry & Noncrystalline $\mathrm{SiO}_{2}$, quartz, halite, pyrite \\
\hline 32878 & $2 \mathrm{H}-2,37.5-40$ & Pumice clast—black & Routine chemistry & Noncrystalline $\mathrm{SiO}_{2}$, halite, pyrite \\
\hline 32875 & $2 \mathrm{H}-4,88-90$ & Altered clay matrix, pumice horizon & Routine chemistry & Quartz, muscovite \\
\hline 32881 & $2 \mathrm{H}-4,115-117$ & Melting pumice & Routine chemistry & Muscovite, halite, pyrite, quartz \\
\hline 32880 & $2 \mathrm{H}-5,45-47$ & Chlorite and pyrite alteration, $\mathrm{H}_{2} \mathrm{~S}$ smell & Routine chemistry & Muscovite, pyrite, quartz, halite (trace) \\
\hline 32884 & $2 \mathrm{H}-6,26-28$ & Clay, dark brown & Routine chemistry & Quartz, muscovite/illite/montmorillonite, pyrite, cristobalite (minimal), halite \\
\hline 32886 & $2 \mathrm{H}-7,80-82$ & Clay, dark brown & Routine chemistry & Quartz, muscovite, pyrite, Mg chlorite \\
\hline 32955 & $3 \mathrm{H}-1,8-10$ & Gray clay & Routine chemistry & Quartz, muscovite, pyrite, Mg chlorite \\
\hline 32959 & $3 \mathrm{H}-2,26-28$ & Gray clay & Routine chemistry & Pyrite, muscovite/illite/montmorillonite, anorthite, quartz, halite (trace) \\
\hline 32960 & $3 \mathrm{H}-3,19-20$ & Interesting sand & XRD only & Quartz, anorthite, pyrite, muscovite \\
\hline 32961 & $3 \mathrm{H}-3,30-32$ & Gray clay & Routine chemistry & Quartz, muscovite, pyrite \\
\hline 32965 & $3 \mathrm{H}-4,96-98$ & Gray clay & Routine chemistry & Quartz, muscovite, pyrite, halite \\
\hline 32968 & $3 \mathrm{H}-4,28.5-30.5$ & Light gray clay & Routine chemistry & Muscovite/lllite/montmorillonite, pyrite, halite \\
\hline 32970 & $3 \mathrm{H}-5,27-29$ & Gray clay & Routine chemistry & Quartz, pyrite, muscovite \\
\hline 32971 & $3 \mathrm{H}-5,83-85$ & Gray clay and white spots & Routine chemistry & Pyrite, muscovite, illite/montmorillonite \\
\hline 32974 & $3 \mathrm{H}-7,50-52$ & Gray clay & Routine chemistry & Dolomite, quartz, pyrite, muscovite/illite/montmorillonite \\
\hline 32975 & $3 \mathrm{H}-8,116-118$ & Dark gray clay & Routine chemistry & Quartz, pyrite, muscovite, Mg chlorite (trace) \\
\hline 32995 & $3 \mathrm{H}-9,85-87$ & White to gray mottled & Routine chemistry & Muscovite/Illite/Montmorillonite, pyrite, copper sulfide, quartz \\
\hline 32997 & $3 \mathrm{H}-10,40-42$ & Dark gray clay & Routine chemistry & Quartz, Pyrite, muscovite \\
\hline 32998 & $3 \mathrm{H}-\mathrm{CC}, 70-72$ & Dark gray clay & Routine chemistry & Quartz, dolomite, muscovite, pyrite, Mg chlorite \\
\hline 33220 & $4 \mathrm{H}-1,47-49$ & Dark gray clay & Routine chemistry & Mg chlorite, pyrite, dolomite, clinopyroxene ???, halite \\
\hline 33181 & $4 \mathrm{H}-2,2-4$ & Sulfate-carbonate concretions & XRD only & Monetite $\left(\mathrm{CaHPO}_{4}\right)$, calcite, quartz \\
\hline 33222 & $4 \mathrm{H}-5,80-82$ & Pale gray mottled clay & Routine chemistry & Mg chlorite, pyrite, quartz (trace) \\
\hline 33224 & $4 \mathrm{H}-6,80-82$ & Dark gray clay & Routine chemistry & Mg chlorite, pyrite, muscovite \\
\hline 33226 & $4 \mathrm{H}-7,70-72$ & Very pale gray clay & Routine chemistry & Mg chlorite, muscovite, pyrite \\
\hline 33228 & $4 \mathrm{H}-8,91-93$ & Silicified altered volcaniclastic clast & Routine chemistry & Quartz, pyrite, muscovite \\
\hline 33230 & $4 \mathrm{H}-10,60-62$ & Pale gray mottled clay & Routine chemistry & Mg chlorite, pyrite, muscovite, quartz \\
\hline 33232 & $4 \mathrm{H}-\mathrm{CC}, 14-16$ & Very pale gray clay & Routine chemistry & Quartz, pyrite, Mg chlorite, muscovite \\
\hline 33254 & $5 \mathrm{H}-3,45-47$ & Pale indurated clay & Routine chemistry & Mg chlorite, pyrite, muscovite, quartz \\
\hline 33256 & $5 \mathrm{H}-4,30-32$ & Soupy pale gray clay & Routine chemistry & Pyrite, muscovite, Mg chlorite \\
\hline 33258 & $5 \mathrm{H}-5,68-70$ & Sandy clay with quartz & Routine chemistry & Quartz, pyrite, muscovite, wairakite $\left[\mathrm{CaAl}_{2} \mathrm{Si}_{4} \mathrm{O}_{10} \cdot 2 \mathrm{H}_{2} \mathrm{O}\right]$ ??? \\
\hline 33286 & $6 \mathrm{H}-2,38-40$ & Indurated pale gray clay & Routine chemistry & Quartz, muscovite, pyrite, halite \\
\hline 33288 & $6 \mathrm{H}-3,80-82$ & Indurated pale gray clay & Routine chemistry & Quartz, muscovite, Mg chlorite, pyrite, halite \\
\hline 33290 & $6 \mathrm{H}-5,6 \mathrm{H}-7-6 \mathrm{H}-9$ & Hard silicified gray volcaniclastic clast & Routine chemistry & Quartz, muscovite, pyrite \\
\hline 33292 & $6 \mathrm{H}-\mathrm{CC}, 10-12$ & Soupy pale gray clay & Routine chemistry & Mg chlorite, muscovite, quartz, pyrite \\
\hline 33303 & $8 \mathrm{H}-\mathrm{CC}, 6-8$ & Sticky pale gray clay with redrill fragments & Routine chemistry & Quartz, Mg chlorite, muscovite, pyrite (3 last phases trace) \\
\hline 33326 & $9 \mathrm{X}-1,14-16$ & Silicified sugary altered volcaniclastic clast & Routine chemistry & Quartz, muscovite, Mg chlorite, pyrite \\
\hline 33327 & $9 X-2,64-66$ & Gritty sticky gray clay & Routine chemistry & Quartz, muscovite, Mg chlorite, pyrite \\
\hline 33330 & $9 \mathrm{X}-\mathrm{CC}, 27-29$ & Very hard indurated gray clay & Routine chemistry & Quartz, Mg chlorite, anhydrite, pyrite \\
\hline 33332 & $10 \mathrm{H}-\mathrm{CC}, 5-7$ & Silicified volcanic rock & Routine chemistry & Quartz, Mg chlorite, muscovite, pyrite (3 last phases trace) \\
\hline 33333 & $11 X-1,3-5$ & Silicified feldsparphyric volcanic rock & Routine chemistry & Quartz, pyrite, Mg chlorite, anhydrite, muscovite \\
\hline 33335 & $11 X-C C, 30-32$ & Hard indurated clay with anhydrite veining & Routine chemistry & Quartz, anhydrite, Mg chlorite, muscovite, pyrite (trace) \\
\hline 33362 & $12 \mathrm{H}-2,74-76$ & Hard indurated clay with anhydrite veining & Routine chemistry & Anhydrite, quartz, muscovite, pyrite, Mg chlorite (trace) \\
\hline 33387 & $13 \mathrm{~T}-1,28-30$ & Unconsolidated gray mud & Routine chemistry & Quartz, muscovite, Mg chlorite, pyrite \\
\hline 33389 & $13 \mathrm{~T}-1,46-47$ & Consolidated gray clast & XRD only & Quartz, pyrite, muscovite, Mg chlorite (trace) \\
\hline 33390 & $13 \mathrm{~T}-2,79.5-81.5$ & Gray mud matrix & Routine chemistry & Quartz, muscovite, Mg chlorite, anhydrite, pyrite \\
\hline 33393 & $13 \mathrm{~T}-3,59-61$ & Gray mud matrix with clast & Routine chemistry & Quartz, muscovite, Mg chlorite, halite, pyrite \\
\hline 33394 & $13 T-4,22-24$ & Gray mud matrix with clast & Routine chemistry & Quartz, muscovite, Mg chlorite, halite, pyrite \\
\hline 33415 & $14 \mathrm{~T}-1,18-20$ & Gray mud matrix & Routine chemistry & Mg chlorite, pyrite, quartz \\
\hline 33417 & $14 \mathrm{~T}-2,51-53$ & Hard dark gray clast with white spots & Routine chemistry & Quartz, muscovite, anhydrite, pyrite \\
\hline
\end{tabular}


Table T7 (continued).

\begin{tabular}{|c|c|c|c|c|}
\hline $\begin{array}{l}\text { Sample } \\
\text { number }\end{array}$ & $\begin{array}{l}\text { Core, section, } \\
\text { interval }(\mathrm{cm})\end{array}$ & Lithology & Subsampled for & Result \\
\hline 33420 & $14 \mathrm{~T}-3,42-44$ & Gray mud matrix & Routine chemistry & Quartz, muscovite, pyrite, Mg chlorite \\
\hline 33408 & 15T-CC, 17-19 & Gray hydrothermal clay & Routine chemistry & Quartz, muscovite, Mg chlorite, pyrite \\
\hline 33431 & $16 \mathrm{~T}-1,7-9$ & Gray hydrothermal clay, with silica-anhydrite veins & Routine chemistry & Quartz, muscovite, pyrite, Mg chlorite, anhydrite \\
\hline 33433 & $16 \mathrm{~T}-2,10-12$ & Gray hydrothermal clay, with silica-anhydrite veins & Routine chemistry & Quartz, pyrite, muscovite, halite \\
\hline 33612 & $17 \mathrm{~T}-1,34-36$ & Gray hydrothermal clay, with silica-anhydrite veins & Routine chemistry & Quartz, pyrite, anhydrite, muscovite \\
\hline 33614 & 17T-2, 20-22 & Gray hydrothermal clay, with silica-anhydrite veins & Routine chemistry & Muscovite, pyrite, quartz, Mg chlorite, anhydrite \\
\hline 33617 & $17 \mathrm{~T}-3,40-42$ & Gray hydrothermal clay, with silica-anhydrite veins & Routine chemistry & Anhydrite, quartz, muscovite, pyrite \\
\hline 33619 & $17 \mathrm{~T}-4,40-42$ & Gray hydrothermal clay, with silica-anhydrite veins & Routine chemistry & Anhydrite, pyrite, muscovite, quartz \\
\hline 33632 & $18 \mathrm{~T}-2,34-36$ & Dark gray indurated mud & Routine chemistry & Pyrite, muscovite, Mg chlorite \\
\hline 33634 & $18 \mathrm{~T}-3,83-85$ & Pale bluish gray clay with anhydrite & Routine chemistry & Anhydrite, muscovite, pyrite, unidentified phyllosilicate (maybe kaolinite ???) \\
\hline 33636 & 18T-CC, $12-14$ & Pale green clay & Routine chemistry & Mg chlorite, quartz, unidentified phyllosilicate (maybe kaolinite ???) \\
\hline 33638 & 19T-CC, 15-17 & Gray clay with silicified volcaniclastic fragments & Routine chemistry & Quartz, anhydrite, pyrite, muscovite \\
\hline 33652 & $20 \mathrm{~T}-1,30-32$ & Pale gray siliceous sand and hydrothermal clay & Routine chemistry & Quartz, muscovite, pyrite \\
\hline 33654 & 20T-CC, 36.5-39 & Siliceous nodule & Routine chemistry & Quartz, pyrite (trace) \\
\hline 33679 & $21 \mathrm{~T}-2,74-76$ & Sugary white sandy clay & Routine chemistry & Quartz, muscovite, unidentified phyllosilicate (maybe kaolinite ???) \\
\hline 33681 & $21 \mathrm{~T}-3,79-81$ & Hydrothermal breccia, with clast and clay & Routine chemistry & Quartz, anhydrite, pyrite, muscovite, Mg chlorite, siderite ??? \\
\hline 33656 & $22 \mathrm{X}-1,7-10$ & Silica clay altered volcaniclastic clast & Routine chemistry & Quartz, pyrite, muscovite \\
\hline 33658 & $22 \mathrm{X}-\mathrm{CC}, 3-5$ & Pale gray laminated indurated clay & Routine chemistry & Muscovite, pyrite, Mg chlorite, anhydrite \\
\hline 33660 & $22 \mathrm{X}-\mathrm{CC}, 10-12$ & Dark gray indurated clay & Routine chemistry & Quartz, anhydrite, muscovite, Mg chlorite, pyrite \\
\hline 33940 & $23 X-1,5-8$ & White silicified vesicular volcanic clast with pyrite & Routine chemistry & Quartz, muscovite, pyrite \\
\hline 33942 & $23 X-2,13-15$ & Pale gray gritty hydrothermal clay & Routine chemistry & Quartz, muscovite, pyrite \\
\hline 34021 & $24 \mathrm{~T}-1,11-13$ & White silicified vesicular volcanic clast with pyrite & Routine chemistry & Quartz, Mg chlorite, muscovite, pyrite, halite \\
\hline 34023 & $24 \mathrm{~T}-1,22-24$ & Pale gray gritty hydrothermal clay & Routine chemistry & Quartz, muscovite, pyrite, anhydrite, Mg chlorite \\
\hline 34037 & $24 \mathrm{~T}-2,11-12$ & White silicified vesicular volcanic clast with pyrite & XRD only_mineralogy of clast & Quartz, muscovite, pyrite, Mg chlorite \\
\hline 34035 & $24 \mathrm{~T}-2,90-92$ & Pale gray gritty hydrothermal clay & Routine chemistry & Quartz, muscovite, Mg chlorite, pyrite \\
\hline 34034 & $24 \mathrm{~T}-3,55-57$ & Pale gray gritty hydrothermal clay & Routine chemistry & Quartz, muscovite, Mg chlorite, anhydrite, pyrite \\
\hline 34038 & $24 \mathrm{~T}-4,49.5-51.5$ & Pale gray gritty hydrothermal clay & Routine chemistry & Quartz, muscovite, Mg chlorite, pyrite \\
\hline 34040 & $24 \mathrm{~T}-\mathrm{CC}, 40-42$ & Silicified flow-banded volcanic clast & Routine chemistry & Quartz, muscovite, Mg chlorite, pyrite \\
\hline 34059 & $25 \mathrm{~T}-1,28.5-30.5$ & Pale gray gritty hydrothermal clay & Routine chemistry & Quartz, muscovite, Mg chlorite, pyrite \\
\hline 34062 & $25 \mathrm{~T}-\mathrm{CC}, 0-4$ & Silicified brecciated volcanic clast & Routine chemistry & Quartz, pyrite, muscovite, halite \\
\hline 34091 & $26 \mathrm{~T}-\mathrm{CC}, 0-1$ & Silicified pebbles of redrill & Routine chemistry & Quartz, pyrite, anhydrite, muscovite \\
\hline 34463 & $30 \mathrm{X}-1,10-12$ & Silicified pumiceous altered volcanic clast & Routine chemistry & Quartz, Mg chlorite \\
\hline
\end{tabular}

Phases listed in approximate order of decreasing abundance.

Table T8. Composition of interstitial pore water, Site C0014. This table is available in an oversized format. 
Table T9. Concentrations of hydrocarbons observed in safety gas vials, Site C0014.

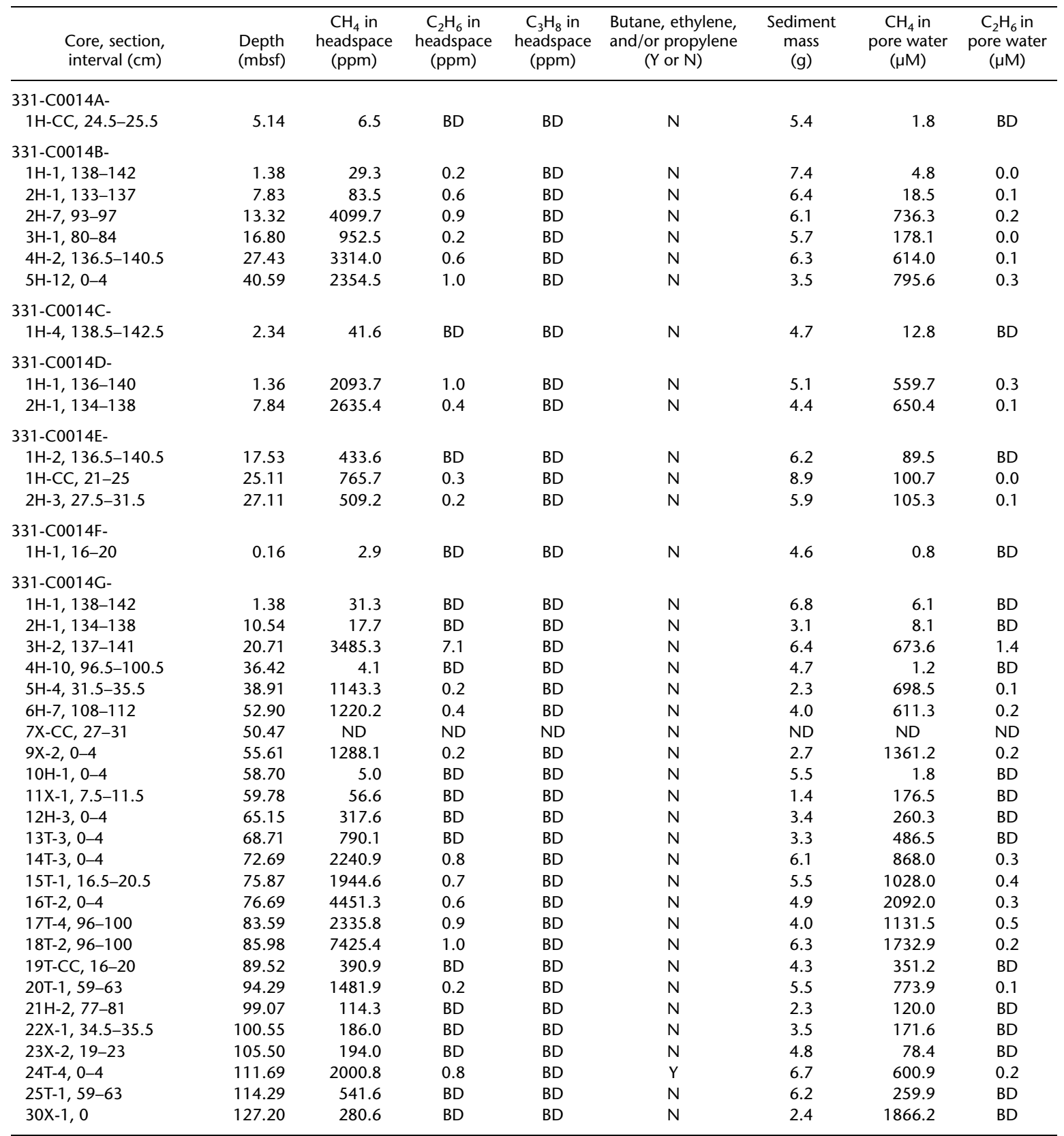

$\mathrm{BD}=$ below detection, $\mathrm{ND}=$ no data 
Table T10. Concentrations of hydrocarbons observed in void gas samples, Site C0014.

\begin{tabular}{|c|c|c|c|c|c|c|c|c|}
\hline $\begin{array}{l}\text { Hole, core, section, } \\
\text { interval }(\mathrm{cm})\end{array}$ & $\begin{array}{l}\text { Depth } \\
\text { (mbsf) }\end{array}$ & $\begin{array}{c}\mathrm{CH}_{4} \text { in } \\
\text { headspace } \\
(\mathrm{ppm})\end{array}$ & $\begin{array}{c}\mathrm{C}_{2} \mathrm{H}_{6} \text { in } \\
\text { headspace } \\
(\mathrm{ppm})\end{array}$ & $\begin{array}{c}\mathrm{C}_{3} \mathrm{H}_{8} \text { in } \\
\text { headspace } \\
(\mathrm{ppm})\end{array}$ & Methane/Ethane & $\begin{array}{l}\text { Gas injected } \\
\text { into vial } \\
(\mathrm{mL})\end{array}$ & $\begin{array}{c}\text { Gas } \mathrm{CH}_{4} \\
\text { content } \\
(\%)\end{array}$ & $\begin{array}{c}\text { Gas } \mathrm{C}_{2} \mathrm{H}_{6} \\
\text { content } \\
(\mathrm{ppm})\end{array}$ \\
\hline \multicolumn{9}{|l|}{$331-$} \\
\hline C0014B-2H-4, 67 & 10.65 & ND & ND & ND & ND & ND & ND & ND \\
\hline C0014D-2H-6, 0 & 12.61 & $15,762.0$ & 2.2 & 0 & 7,073 & 4 & 9.5 & 13.4 \\
\hline C0014B-2H-7, 40 & 12.79 & ND & ND & ND & ND & ND & ND & ND \\
\hline C0014B-3H-3, 100 & 18.61 & ND & ND & ND & ND & ND & ND & ND \\
\hline C0014B-3H-5, 32 & 20.18 & $41,595.0$ & 5.4 & 0 & 7,681 & 4 & 25.0 & 32.5 \\
\hline C0014E-1H-4, 25 & 19.22 & $16,619.0$ & 2.1 & 0 & 7,836 & 4 & 10.0 & 12.7 \\
\hline C0014E-1H-5, 98 & 21.36 & $7,514.0$ & 0.9 & 0 & 8,115 & 4 & 4.5 & 5.6 \\
\hline C0014B-3H-7, 118 & 23.03 & ND & ND & ND & ND & ND & ND & ND \\
\hline C0014B-4H-4, 46 & 29.34 & $43,591.0$ & 6.3 & 0 & 6,878 & 4 & 26.2 & 38.0 \\
\hline C0014E-2H-6, 71 & 30.67 & ND & ND & ND & ND & ND & ND & ND \\
\hline C0014B-4H-7, 68.5 & 32.62 & $26,764.1$ & 3.8 & 0 & 6,966 & 5 & 16.1 & 23.1 \\
\hline C0014G-3H-6, 22.5 & 24.21 & $74,392.7$ & 9.4 & 0 & 7,933 & 4 & 44.6 & 56.3 \\
\hline C0014G-3H-7, 34 & 24.81 & $28,968.1$ & 3.8 & 0 & 7,585 & 4 & 17.4 & 22.9 \\
\hline
\end{tabular}

$\mathrm{ND}=$ no data

Table T11. Concentrations of hydrocarbons observed in safety gas vials, Site C0014. (Continued on next two pages.)

\begin{tabular}{|c|c|c|c|c|c|c|}
\hline $\begin{array}{l}\text { Core, section, } \\
\text { interval }(\mathrm{cm})\end{array}$ & $\begin{array}{l}\text { Depth } \\
\text { (mbsf) }\end{array}$ & $\begin{array}{c}\mathrm{H}_{2} \text { in } \\
\text { science gas } \\
\text { (ppm) }\end{array}$ & $\begin{array}{c}\mathrm{CH}_{4} \text { in } \\
\text { science gas } \\
(\mathrm{ppm})\end{array}$ & $\begin{array}{l}\text { Sample } \\
\text { mass } \\
(\mathrm{g})\end{array}$ & $\begin{array}{l}\mathrm{H}_{2} \text { in } \\
\text { pore water } \\
(\mathrm{nM})\end{array}$ & $\begin{array}{l}\mathrm{CH}_{4} \text { in } \\
\text { pore water } \\
(\mu \mathrm{M})\end{array}$ \\
\hline \multicolumn{7}{|l|}{ 331-C0014A- } \\
\hline $1 \mathrm{H}-3,0-4$ & 1.90 & $\mathrm{BD}$ & 156.5 & 7.97 & $\mathrm{BD}$ & 8.5 \\
\hline $1 \mathrm{H}-4,0-4$ & 2.80 & $\mathrm{BD}$ & 306.8 & 7.39 & BD & 21.1 \\
\hline $1 \mathrm{H}-5,4-5$ & 4.31 & 1.0429 & 7.9 & 4.63 & 123.9 & 0.9 \\
\hline $1 \mathrm{H}-5,58-62$ & 4.85 & $\mathrm{BD}$ & 74.2 & 4.08 & $\mathrm{BD}$ & 10.0 \\
\hline $1 \mathrm{H}-\mathrm{CC}, 24.5-25.5$ & 5.14 & 0.09 & $\mathrm{BD}$ & 3.41 & 20.2 & $\mathrm{BD}$ \\
\hline \multicolumn{7}{|l|}{ 331-C0014B- } \\
\hline $1 \mathrm{H}-1,138-142$ & 1.38 & $\mathrm{BD}$ & 9.3 & 6.38 & BD & 0.8 \\
\hline $1 \mathrm{H}-2,135-139$ & 2.77 & BD & $1,459.5$ & 5.56 & BD & 149.5 \\
\hline $1 \mathrm{H}-3,138-142$ & 4.19 & $\mathrm{BD}$ & $4,087.4$ & 5.58 & BD & 438.2 \\
\hline $1 \mathrm{H}-4,137-141$ & 5.60 & $\mathrm{BD}$ & $3,252.5$ & 4.12 & BD & 628.8 \\
\hline $1 \mathrm{H}-5,103-107$ & 6.67 & $\mathrm{BD}$ & $2,575.8$ & 6.46 & BD & 285.0 \\
\hline $2 \mathrm{H}-1,133-137$ & 7.83 & $\mathrm{BD}$ & 79.0 & 5.79 & BD & 8.2 \\
\hline $2 \mathrm{H}-2,66-70$ & 8.53 & $\mathrm{BD}$ & 27.0 & 2.88 & BD & 8.0 \\
\hline $2 \mathrm{H}-3,137-141$ & 9.94 & $\mathrm{BD}$ & 310.9 & 6.64 & $\mathrm{BD}$ & 19.6 \\
\hline $2 \mathrm{H}-4,71-75$ & 10.69 & 0.1 & $1,104.1$ & 4.99 & 12.7 & 119.2 \\
\hline $2 \mathrm{H}-5,100-104$ & 11.73 & $\mathrm{BD}$ & $6,980.4$ & 7.07 & $\mathrm{BD}$ & 492.2 \\
\hline $2 \mathrm{H}-6,58-62$ & 12.35 & BD & $4,808.7$ & 6.52 & BD & 343.5 \\
\hline $2 \mathrm{H}-7,93-97$ & 13.32 & $\mathrm{BD}$ & $2,441.3$ & 6.25 & BD & 173.1 \\
\hline $2 \mathrm{H}-8,47.5-51.5$ & 13.84 & $\mathrm{BD}$ & 275.0 & 5.24 & $\mathrm{BD}$ & 30.4 \\
\hline $3 \mathrm{H}-1,80-84$ & 16.80 & 1.8 & 12.9 & 5.76 & 120.7 & 0.9 \\
\hline $3 \mathrm{H}-2,73-77$ & 17.57 & $\mathrm{BD}$ & 807.2 & 5.25 & $\mathrm{BD}$ & 73.1 \\
\hline $3 \mathrm{H}-3,97-101$ & 18.58 & BD & 593.3 & 5.59 & BD & 39.6 \\
\hline $3 \mathrm{H}-4,119.5-123.5$ & 19.82 & $\mathrm{BD}$ & 249.4 & 5.43 & $\mathrm{BD}$ & 22.2 \\
\hline $3 \mathrm{H}-5,135-139$ & 21.21 & $\mathrm{BD}$ & 176.5 & 6.58 & BD & 10.0 \\
\hline $3 \mathrm{H}-6,59-63$ & 21.84 & $\mathrm{BD}$ & 864.9 & 4.95 & $\mathrm{BD}$ & 86.5 \\
\hline $3 \mathrm{H}-7,115-119$ & 23.03 & $\mathrm{BD}$ & 923.0 & 4.95 & BD & 141.5 \\
\hline $4 \mathrm{H}-2,136.5-140.5$ & 27.43 & $\mathrm{BD}$ & $5,753.3$ & 5.56 & $\mathrm{BD}$ & 589.2 \\
\hline $4 \mathrm{H}-3,137-141$ & 28.84 & $\mathrm{BD}$ & $3,014.6$ & 6.74 & BD & 286.4 \\
\hline $4 \mathrm{H}-4,118.5-122.5$ & 30.07 & BD & 389.0 & 5.68 & BD & 46.9 \\
\hline $4 \mathrm{H}-6,135-139$ & 31.89 & $\mathrm{BD}$ & 185.4 & 4.43 & BD & 22.5 \\
\hline $4 \mathrm{H}-7,137-141$ & 33.30 & $\mathrm{BD}$ & 256.3 & 6.00 & BD & 22.7 \\
\hline $4 \mathrm{H}-8,137-141$ & 34.71 & $\mathrm{BD}$ & 258.3 & 5.07 & $\mathrm{BD}$ & 27.2 \\
\hline $5 \mathrm{H}-12,0-4$ & 40.59 & $\mathrm{BD}$ & 513.0 & 2.72 & $\mathrm{BD}$ & 111.5 \\
\hline $5 \mathrm{H}-13,106-110$ & 42.55 & 18.3 & 339.5 & 5.48 & $1,768.7$ & 32.8 \\
\hline $5 \mathrm{H}-14,123.5-127.5$ & 43.82 & 71.4 & 70.1 & 3.44 & $24,658.5$ & 24.2 \\
\hline \multicolumn{7}{|l|}{ 331-C0014C- } \\
\hline $1 \mathrm{H}-4,138.5-142.5$ & 2.34 & $\mathrm{BD}$ & 8.2 & 4.73 & 0.0 & 1.1 \\
\hline $1 \mathrm{H}-5,140-144$ & 3.78 & 0.2 & 70.0 & 5.03 & 23.8 & 8.2 \\
\hline
\end{tabular}


Table T11 (continued). (Continued on next page.)

\begin{tabular}{|c|c|c|c|c|c|c|}
\hline $\begin{array}{l}\text { Core, section, } \\
\text { interval }(\mathrm{cm})\end{array}$ & $\begin{array}{l}\text { Depth } \\
\text { (mbsf) }\end{array}$ & $\begin{array}{c}\mathrm{H}_{2} \text { in } \\
\text { science gas } \\
(p p m)\end{array}$ & $\begin{array}{c}\mathrm{CH}_{4} \text { in } \\
\text { science gas } \\
\text { (ppm) }\end{array}$ & $\begin{array}{l}\text { Sample } \\
\text { mass } \\
\text { (g) }\end{array}$ & $\begin{array}{l}\mathrm{H}_{2} \text { in } \\
\text { pore water } \\
(\mathrm{nM})\end{array}$ & $\begin{array}{c}\mathrm{CH}_{4} \text { in } \\
\text { pore water } \\
(\mu \mathrm{M})\end{array}$ \\
\hline $1 \mathrm{H}-6,116.5-120.5$ & 4.99 & 0.3 & 52.9 & 3.16 & 52.0 & 9.0 \\
\hline \multicolumn{7}{|l|}{ 331-C0014D- } \\
\hline $1 \mathrm{H}-1,136-140$ & 1.36 & $\mathrm{BD}$ & 279.3 & 5.06 & $\mathrm{BD}$ & 32.5 \\
\hline $1 \mathrm{H}-2,136.5-140.5$ & 2.77 & $\mathrm{BD}$ & 36.8 & 2.44 & $\mathrm{BD}$ & 10.3 \\
\hline $1 \mathrm{H}-3,138-142$ & 4.19 & 1.4 & 66.0 & 4.47 & 128.8 & 6.2 \\
\hline $1 \mathrm{H}-4,85-89$ & 5.08 & $\mathrm{BD}$ & 8.1 & 4.86 & $\mathrm{BD}$ & 0.8 \\
\hline $2 \mathrm{H}-1,134-138$ & 7.84 & 0.2 & $1,238.7$ & 4.29 & 21.2 & 145.8 \\
\hline $2 \mathrm{H}-2,137-141$ & 9.25 & $\mathrm{BD}$ & 549.3 & 4.79 & $\mathrm{BD}$ & 44.3 \\
\hline $2 \mathrm{H}-3,139-143$ & 10.68 & $\mathrm{BD}$ & 133.7 & 5.02 & $B D$ & 12.0 \\
\hline $2 \mathrm{H}-4,123.5-127.5$ & 11.96 & $\mathrm{BD}$ & 28.4 & 4.41 & $\mathrm{BD}$ & 4.4 \\
\hline $2 \mathrm{H}-6,95.5-99.5$ & 13.56 & $\mathrm{BD}$ & 147.2 & 6.36 & $\mathrm{BD}$ & 13.1 \\
\hline \multicolumn{7}{|l|}{ 331-C0014E- } \\
\hline $1 \mathrm{H}-2,136.5-140.5$ & 17.53 & $\mathrm{BD}$ & 317.2 & 5.76 & $\mathrm{BD}$ & 29.8 \\
\hline $1 \mathrm{H}-3,136.5-140.5$ & 18.93 & 0.4 & 33.0 & 7.03 & 51.1 & 3.8 \\
\hline $1 \mathrm{H}-4,137-141$ & 20.34 & BD & 117.7 & 5.86 & $\mathrm{BD}$ & 10.9 \\
\hline $1 \mathrm{H}-5,94-98$ & 21.32 & $\mathrm{BD}$ & 691.2 & 5.86 & $\mathrm{BD}$ & 51.1 \\
\hline $1 \mathrm{H}-6,128.5-132.5$ & 22.65 & $\mathrm{BD}$ & 124.0 & 7.58 & $\mathrm{BD}$ & 12.4 \\
\hline $1 \mathrm{H}-\mathrm{CC}, 21-25$ & 25.11 & 0.7 & 346.1 & 6.41 & 82.7 & 40.8 \\
\hline $2 \mathrm{H}-3,27.5-31.5$ & 27.11 & $\mathrm{BD}$ & 97.7 & 4.67 & $\mathrm{BD}$ & 10.9 \\
\hline $2 \mathrm{H}-4,136-140$ & 28.51 & $\mathrm{BD}$ & 115.6 & 5.87 & $\mathrm{BD}$ & 11.6 \\
\hline $2 \mathrm{H}-5,137-141$ & 29.92 & $\mathrm{BD}$ & 50.3 & 4.01 & $\mathrm{BD}$ & 6.0 \\
\hline $2 \mathrm{H}-6,137.5-141.5$ & 31.33 & 6.8 & 726.9 & 5.44 & $1,290.8$ & 138.1 \\
\hline \multicolumn{7}{|l|}{ 331-C0014F- } \\
\hline $1 \mathrm{H}-1,17-21$ & 0.17 & $1,385.0$ & $\mathrm{BD}$ & 4.60 & $166,790.1$ & $\mathrm{BD}$ \\
\hline $1 \mathrm{H}-2,96.5-100.5$ & 1.18 & 52.0 & 5.5 & 3.52 & $8,842.0$ & 0.9 \\
\hline \multicolumn{7}{|l|}{ 331-C0014G- } \\
\hline $1 \mathrm{H}-1,138-142$ & 1.42 & $\mathrm{BD}$ & 10.4 & 6.38 & $\mathrm{BD}$ & 0.9 \\
\hline $1 \mathrm{H}-2,137-141$ & 2.83 & BD & 19.5 & 3.82 & BD & 3.3 \\
\hline $1 \mathrm{H}-3,135.5-139.5$ & 4.19 & $\mathrm{BD}$ & 10.0 & 4.27 & $\mathrm{BD}$ & 1.7 \\
\hline $1 \mathrm{H}-4,137.5-141.5$ & 5.64 & $\mathrm{BD}$ & 23.7 & 6.97 & $\mathrm{BD}$ & 2.2 \\
\hline $1 \mathrm{H}-5,137-141$ & 7.05 & 0.6 & 3.2 & 1.34 & 415.0 & 2.0 \\
\hline $1 \mathrm{H}-6,137-141$ & 8.46 & $\mathrm{BD}$ & 2.9 & 1.80 & $\mathrm{BD}$ & 1.1 \\
\hline $2 \mathrm{H}-1,134-138$ & 10.58 & $\mathrm{BD}$ & 5.0 & 1.37 & $\mathrm{BD}$ & 2.7 \\
\hline $2 \mathrm{H}-2,136.5-140.5$ & 11.99 & 0.5 & 6.4 & 1.88 & 125.6 & 1.8 \\
\hline $2 \mathrm{H}-3,136.5-140.5$ & 13.39 & 0.8 & 10.9 & 2.32 & 174.5 & 2.5 \\
\hline $2 \mathrm{H}-4,136.5-140.5$ & 14.80 & 2.8 & 12.8 & 2.80 & 582.6 & 2.7 \\
\hline $2 \mathrm{H}-5,138-142$ & 16.22 & $\mathrm{BD}$ & $1,952.7$ & 5.33 & $\mathrm{BD}$ & 173.5 \\
\hline $2 \mathrm{H}-6,140.5-144.5$ & 17.66 & $\mathrm{BD}$ & 488.8 & 4.15 & $\mathrm{BD}$ & 89.8 \\
\hline $3 \mathrm{H}-2,137-141$ & 20.75 & 1.2 & $1,050.8$ & 5.73 & 121.3 & 104.3 \\
\hline $3 \mathrm{H}-4,137-141$ & 22.58 & $\mathrm{BD}$ & 197.4 & 6.43 & $\mathrm{BD}$ & 16.9 \\
\hline $3 \mathrm{H}-6,45-49$ & 24.47 & $\mathrm{BD}$ & 292.8 & 4.02 & $\mathrm{BD}$ & 56.2 \\
\hline $3 \mathrm{H}-7,68.5-72.5$ & 25.20 & 4.8 & 350.3 & 3.91 & 896.1 & 65.0 \\
\hline $3 \mathrm{H}-8,142-146$ & 26.66 & 3.2 & 538.0 & 6.18 & 625.9 & 106.6 \\
\hline $3 \mathrm{H}-10,50.5-54.5$ & 28.21 & $\mathrm{BD}$ & 514.6 & 4.31 & $\mathrm{BD}$ & 86.2 \\
\hline $4 \mathrm{H}-4,50-54$ & 30.41 & $\mathrm{BD}$ & 1.3 & 4.88 & $\mathrm{BD}$ & 0.2 \\
\hline $4 \mathrm{H}-6,97-101$ & 32.43 & $\mathrm{BD}$ & 15.2 & 4.13 & $\mathrm{BD}$ & 2.4 \\
\hline $4 \mathrm{H}-7,96.5-100.5$ & 33.43 & 3.9 & 30.8 & 5.31 & 271.7 & 2.2 \\
\hline $4 \mathrm{H}-9,96.5-100.5$ & 35.45 & $2,186.6$ & 37.7 & 3.53 & $381,717.7$ & 6.6 \\
\hline $4 \mathrm{H}-10,96.5-100.5$ & 36.46 & 0.2 & 6.6 & 6.82 & 11.8 & 0.4 \\
\hline $5 \mathrm{H}-4,31.5-35.5$ & 38.95 & 942.2 & 114.1 & 2.34 & $451,124.6$ & 54.6 \\
\hline $6 \mathrm{H}-3,0-4$ & 48.38 & 232.4 & $1,016.9$ & 6.89 & $14,510.5$ & 63.5 \\
\hline $7 X-C C, 27-31$ & 50.51 & 6.0 & 77.5 & 3.59 & $1,494.7$ & 19.2 \\
\hline $9 X-2,0-4$ & 55.65 & 3.1 & 133.8 & 1.17 & $3,108.2$ & 132.7 \\
\hline $10 \mathrm{H}-1,0-4$ & 58.74 & 98.6 & 14.2 & 7.13 & $14,451.4$ & 2.1 \\
\hline $11 X-1,7.5-11.5$ & 59.82 & 1.1 & 30.6 & 1.33 & $1,278.0$ & 34.8 \\
\hline $12 \mathrm{H}-2,0-4$ & 64.37 & $1,418.0$ & 4.9 & 4.60 & $381,635.0$ & 1.3 \\
\hline $12 \mathrm{H}-3,0-4$ & 65.19 & 19.6 & 186.6 & 4.55 & $4,693.4$ & 44.7 \\
\hline 13T-1, 96-100 & 67.70 & 155.5 & 178.9 & 2.20 & $108,767.6$ & 125.2 \\
\hline $13 \mathrm{~T}-3,0-4$ & 68.75 & 24.7 & 91.2 & 2.87 & $8,855.7$ & 32.6 \\
\hline 14T-1, 43.5-47.5 & 71.68 & 46.0 & 581.4 & 3.16 & $17,446.4$ & 220.4 \\
\hline $14 \mathrm{~T}-3,0-4$ & 72.73 & 104.2 & $1,487.7$ & 5.37 & $23,868.2$ & 340.8 \\
\hline 15T-1, 16.5-20.5 & 75.91 & 16.9 & 368.7 & 3.08 & $8,466.4$ & 184.6 \\
\hline $16 \mathrm{~T}-2,0-4$ & 76.73 & 47.7 & 918.7 & 5.14 & $10,453.8$ & 201.3 \\
\hline 17T-2, 96.5-100.5 & 81.62 & 876.8 & 778.5 & 3.53 & $329,086.2$ & 292.2 \\
\hline 17T-4, 96-100 & 83.63 & 8.6 & 416.5 & 4.62 & $1,661.9$ & 80.2 \\
\hline $18 \mathrm{~T}-2,96-100$ & 86.02 & 77.8 & 523.3 & 3.23 & $20,256.8$ & 136.3 \\
\hline $18 \mathrm{~T}-3,96.5-100.5$ & 87.02 & 109.8 & $1,120.5$ & 3.63 & $25,279.6$ & 257.9 \\
\hline
\end{tabular}


Table T11 (continued).

\begin{tabular}{|c|c|c|c|c|c|c|}
\hline $\begin{array}{l}\text { Core, section, } \\
\text { interval }(\mathrm{cm})\end{array}$ & $\begin{array}{l}\text { Depth } \\
\text { (mbsf) }\end{array}$ & $\begin{array}{c}\mathrm{H}_{2} \text { in } \\
\text { science gas } \\
\text { (ppm) }\end{array}$ & $\begin{array}{c}\mathrm{CH}_{4} \text { in } \\
\text { science gas } \\
\text { (ppm) }\end{array}$ & $\begin{array}{c}\text { Sample } \\
\text { mass } \\
(g)\end{array}$ & $\begin{array}{l}\mathrm{H}_{2} \text { in } \\
\text { pore water } \\
(\mathrm{nM})\end{array}$ & $\begin{array}{l}\mathrm{CH}_{4} \text { in } \\
\text { pore water } \\
(\mu \mathrm{M})\end{array}$ \\
\hline 19T-CC, 16-20 & 89.56 & 5.0 & 237.7 & 3.79 & $2,644.9$ & 126.8 \\
\hline 20T-1, 59-63 & 94.33 & 2.6 & 271.0 & 5.85 & 624.4 & 64.0 \\
\hline $21 \mathrm{H}-2,77-81$ & 99.11 & $1,421.1$ & 428.0 & 5.91 & $291,669.7$ & 87.8 \\
\hline $22 X-1,34.5-35.5$ & 100.56 & 9.6 & 117.7 & 2.82 & $5,431.6$ & 66.9 \\
\hline $23 X-2,19-23$ & 105.54 & 2.0 & 84.9 & 1.82 & $1,240.1$ & 52.5 \\
\hline 24T-2, 96-100 & 110.70 & $1,656.1$ & 357.5 & 2.21 & $983,851.4$ & 212.4 \\
\hline $24 \mathrm{~T}-4,0-4$ & 111.73 & 276.2 & $1,068.2$ & 5.15 & $50,637.3$ & 195.8 \\
\hline 25T-1, 59-63 & 114.33 & 75.3 & 311.6 & 6.16 & $11,107.2$ & 46.0 \\
\hline $30 X-1,0-4$ & 127.20 & 109.8 & 44.6 & 1.07 & $811,305.1$ & 329.9 \\
\hline 3H-2, 137-141 (2 days) & 20.75 & BD & $1,116.0$ & 5.73 & BD & 110.7 \\
\hline $3 \mathrm{H}-7,68.5-72.5$ (2 days) & 25.20 & $\mathrm{BD}$ & 340.7 & 3.91 & $\mathrm{BD}$ & 63.2 \\
\hline $3 \mathrm{H}-10,50.5-54.5$ (2 days) & 28.21 & $\mathrm{BD}$ & 487.2 & 4.31 & $\mathrm{BD}$ & 81.6 \\
\hline $4 \mathrm{H}-4,50-54$ (2 days) & 30.41 & 0.8 & 7.3 & 4.88 & 128.2 & 1.1 \\
\hline $4 \mathrm{H}-6,97-101$ (2 days) & 32.43 & $\mathrm{BD}$ & 15.2 & 4.13 & $\mathrm{BD}$ & 2.4 \\
\hline $4 \mathrm{H}-7,96.5-100.5$ (2 days) & 33.43 & 20.8 & 47.8 & 5.31 & $1,458.1$ & 3.3 \\
\hline $4 \mathrm{H}-9,96.5-100.5$ (2 days) & 35.45 & $6,650.8$ & 49.6 & 3.53 & $1,161,049.3$ & 8.7 \\
\hline $4 \mathrm{H}-10,96.5-100.5$ (2 days) & 36.46 & 3.8 & 11.6 & 6.82 & 262.0 & 0.8 \\
\hline $5 \mathrm{H}-4,31.5-35.5$ (2 days) & 38.95 & $2,484.1$ & 137.3 & 2.34 & $1,189,436.7$ & 65.7 \\
\hline $6 \mathrm{H}-3,0-4$ (2 days) & 48.38 & $3,011.9$ & $1,265.6$ & 6.89 & $188,043.4$ & 79.0 \\
\hline 7X-CC, 27-31 (2 days) & 50.51 & 35.3 & 376.5 & 3.59 & $8,737.0$ & 93.2 \\
\hline $14 \mathrm{~T}-3,0-4$ (2 days) & 72.73 & 605.4 & $1,376.6$ & 5.37 & $138,675.4$ & 315.3 \\
\hline 16T-2, $0-4$ (2 days) & 76.73 & $9,959.5$ & $1,721.4$ & 5.14 & $2,182,552.3$ & 377.2 \\
\hline $17 \mathrm{~T}-4,96-100$ (2 days) & 83.63 & 11.6 & 651.7 & 4.62 & $2,224.6$ & 125.5 \\
\hline $18 \mathrm{~T}-2,96-100$ (2 days) & 86.02 & $6,040.7$ & $1,205.0$ & 3.23 & $1,573,117.4$ & 313.8 \\
\hline 20T-1, 59-63 (2 days) & 94.33 & 20.2 & 927.0 & 5.85 & $4,780.1$ & 218.9 \\
\hline $24 \mathrm{~T}-2,96-100$ (slimy) & 110.70 & $1,273.4$ & 171.9 & 2.56 & $218,441.8$ & 29.5 \\
\hline $22 X-1,5-9$ (slimy) & 100.29 & 28.0 & 29.1 & 2.65 & $5,164.9$ & 5.4 \\
\hline $21 \mathrm{H}-2,0-4$ (slimy) & 98.34 & $5,579.8$ & 80.4 & 6.12 & $261,943.8$ & 3.8 \\
\hline
\end{tabular}

$\mathrm{BD}=$ below detection. 2 days $=$ samples after 2 days. Slimy = slimy samples. 
Table T12. Carbon, nitrogen, and sulfur, Site C0014. (Continued on next two pages.)

\begin{tabular}{|c|c|c|c|c|c|c|c|c|}
\hline $\begin{array}{l}\text { Core, section, } \\
\text { interval }(\mathrm{cm})\end{array}$ & $\begin{array}{l}\text { Depth } \\
\text { (mbsf) }\end{array}$ & $\begin{array}{c}\text { IC } \\
\text { (wt\%) }\end{array}$ & $\begin{array}{l}\mathrm{CaCO}_{3} \\
\text { (wt\%) }\end{array}$ & $\begin{array}{c}\text { TN } \\
\text { (wt\%) }\end{array}$ & $\begin{array}{c}\text { TC } \\
\text { (wt\%) }\end{array}$ & $\begin{array}{c}\text { TS } \\
\text { (wt\%) }\end{array}$ & $\begin{array}{l}\text { TOC } \\
\text { (wt\%) }\end{array}$ & TOC/TN \\
\hline \multicolumn{9}{|l|}{ 331-C0014A- } \\
\hline $1 \mathrm{H}-1,30.0$ & 0.30 & 1.439 & 11.988 & 0.080 & 2.115 & 0.759 & 0.676 & 8.505 \\
\hline $1 \mathrm{H}-3,30.0$ & 2.20 & 1.203 & 10.024 & 0.086 & 1.945 & 1.587 & 0.742 & 8.674 \\
\hline $1 \mathrm{H}-5,30.0$ & 4.57 & 0.045 & 0.376 & 0.036 & 0.332 & 1.316 & 0.287 & 8.039 \\
\hline $1 \mathrm{H}-\mathrm{CC}, 20.0$ & 5.09 & 0.004 & 0.034 & 0.014 & 0.106 & 1.160 & 0.102 & 7.209 \\
\hline \multicolumn{9}{|l|}{ 331-C0014B- } \\
\hline 1H-1, 19.0 & 0.19 & 3.9172 & 32.642 & 0.053 & 4.375 & 0.27 & 0.458 & 8.562 \\
\hline $1 \mathrm{H}-3,60.0$ & 3.41 & 1.6452 & 13.7095 & 0.079 & 2.261 & 1.607 & 0.616 & 7.803 \\
\hline $1 \mathrm{H}-5,52.0$ & 6.16 & 2.0719 & 17.2651 & 0.071 & 2.683 & 1.210 & 0.611 & 8.554 \\
\hline $2 \mathrm{H}-1,70.0$ & 7.20 & 0.0169 & 0.1408 & 0.088 & 0.797 & 2.032 & 0.780 & 8.887 \\
\hline $2 \mathrm{H}-2,54.0$ & 8.41 & 0.3073 & 2.5607 & 0.037 & 0.622 & 1.942 & 0.314 & 8.442 \\
\hline $2 \mathrm{H}-3,117.0$ & 9.74 & 0.0227 & 0.1892 & 0.063 & 0.634 & 2.540 & 0.611 & 9.701 \\
\hline $2 \mathrm{H}-4,10.0$ & 10.08 & 0.0288 & 0.24 & 0.037 & 0.394 & 2.148 & 0.365 & 9.844 \\
\hline $2 \mathrm{H}-6,11.0$ & 11.88 & 0.0055 & 0.0458 & 0.062 & 1.206 & 6.063 & 1.201 & 19.325 \\
\hline $2 \mathrm{H}-6,57.0$ & 12.34 & 0.001 & 0.0083 & 0.006 & 0.177 & 5.185 & 0.176 & 27.749 \\
\hline $2 \mathrm{H}-9,56.0$ & 14.44 & 0.0055 & 0.0458 & 0.031 & 0.153 & 3.843 & 0.147 & 4.799 \\
\hline $2 \mathrm{H}-11,2.0$ & 15.39 & 0.0038 & 0.0317 & 0.008 & 0.073 & 6.23 & 0.069 & 8.372 \\
\hline $2 \mathrm{H}-12,0.0$ & 16.13 & BD & BD & 0.359 & 0.033 & 5.890 & 0.033 & 0.093 \\
\hline $3 \mathrm{H}-1,48.0$ & 16.48 & 0.0041 & 0.0342 & 0.419 & 0.082 & 4.704 & 0.078 & 0.186 \\
\hline $3 \mathrm{H}-2,24.0$ & 17.08 & 0.0022 & 0.0183 & 0.361 & 0.122 & 5.899 & 0.120 & 0.332 \\
\hline $3 \mathrm{H}-3,44.0$ & 18.05 & 0.0054 & 0.045 & 0.01 & 0.05 & 5.306 & 0.045 & 4.963 \\
\hline $3 \mathrm{H}-4,54.0$ & 19.16 & 0.0016 & 0.0133 & 0.361 & 0.061 & 3.22 & 0.059 & 0.163 \\
\hline $3 \mathrm{H}-5,80.0$ & 20.66 & 0.0018 & 0.015 & 0.258 & 0.037 & 6.124 & 0.036 & 0.138 \\
\hline $3 \mathrm{H}-8,95.0$ & 24.02 & 0.0029 & 0.0242 & 0.018 & 0.020 & 3.614 & 0.017 & 0.936 \\
\hline $3 \mathrm{H}-10,43.0$ & 25.49 & 0.0038 & 0.0317 & 0.035 & 0.058 & 6.702 & 0.054 & 1.563 \\
\hline $4 \mathrm{H}-1,42.0$ & 25.92 & 0.0053 & 0.0442 & $\mathrm{BD}$ & 0.045 & 5.697 & 0.040 & NA \\
\hline $4 \mathrm{H}-2,89.0$ & 26.96 & 0.0015 & 0.0125 & 0.007 & 0.355 & 4.776 & 0.354 & 53.168 \\
\hline $4 \mathrm{H}-3,12.0$ & 27.59 & 0.0033 & 0.0275 & 0.010 & 0.047 & 4.627 & 0.044 & 4.519 \\
\hline $4 \mathrm{H}-4,58.0$ & 29.46 & 0.0031 & 0.0258 & $\mathrm{BD}$ & 0.257 & 4.046 & 0.254 & 4.05 \\
\hline $4 \mathrm{H}-6,13.0$ & 30.67 & 0.0027 & 0.0225 & 0.023 & 0.030 & 2.787 & 0.028 & 1.222 \\
\hline $4 \mathrm{H}-7,39.0$ & 32.32 & BD & BD & $\mathrm{BD}$ & 0.27 & 4.49 & 0.274 & NA \\
\hline $4 \mathrm{H}-8,18.0$ & 33.52 & 0.0016 & 0.0133 & BD & 0.017 & 3.141 & 0.015 & NA \\
\hline $4 \mathrm{H}-9,40.0$ & 35.15 & 0.0014 & 0.0117 & BD & 0.016 & 2.025 & 0.014 & NA \\
\hline $5 \mathrm{H}-3,21.5$ & 35.75 & 0.0046 & 0.0383 & $\mathrm{BD}$ & 0.030 & 3.717 & 0.025 & NA \\
\hline $5 \mathrm{H}-4,30.0$ & 36.79 & 0.0351 & 0.2925 & BD & 0.064 & 3.790 & 0.029 & NA \\
\hline $5 \mathrm{H}-5,12.0$ & 38.01 & 0.0007 & 0.0058 & $\mathrm{BD}$ & 0.081 & 5.812 & 0.080 & NA \\
\hline $5 \mathrm{H}-6,24.0$ & 39.51 & 0.0031 & 0.0258 & 0.008 & 0.054 & 2.727 & 0.051 & 6.499 \\
\hline $5 \mathrm{H}-11,80.0$ & 40.50 & 0.0026 & 0.0217 & $\mathrm{BD}$ & 0.073 & 3.046 & 0.071 & NA \\
\hline $5 \mathrm{H}-12,80.0$ & 41.39 & BD & BD & 0.012 & 0.119 & 5.336 & 0.119 & 10.197 \\
\hline $5 \mathrm{H}-13,104.0$ & 42.53 & 0.0014 & 0.0117 & $\mathrm{BD}$ & 0.019 & 2.393 & 0.018 & NA \\
\hline $5 \mathrm{H}-15,0.0$ & 43.86 & 0.001 & 0.008 & 0.009 & 0.033 & 3.282 & 0.032 & 3.403 \\
\hline \multicolumn{9}{|l|}{ 331-C0014C- } \\
\hline $1 \mathrm{H}-1,12.0$ & 0.12 & 0.001 & 0.004 & 0.047 & 0.605 & 1.684 & 0.604 & 12.956 \\
\hline $1 \mathrm{H}-4,29.0$ & 1.25 & BD & $\mathrm{BD}$ & 0.007 & 0.101 & 0.56 & 0.101 & 14.252 \\
\hline $1 \mathrm{H}-4,97.0$ & 1.93 & 0.001 & 0.006 & $\mathrm{BD}$ & 0.075 & 0.42 & 0.074 & NA \\
\hline $1 \mathrm{H}-6,37.5$ & 4.20 & BD & $\mathrm{BD}$ & $\mathrm{BD}$ & 0.099 & 0.65 & 0.099 & NA \\
\hline \multicolumn{9}{|l|}{ 331-C0014D- } \\
\hline $1 \mathrm{H}-1,2.0$ & 0.02 & 0.75 & 6.25 & 0.015 & 0.834 & 1.113 & 0.083 & 5.485 \\
\hline $1 \mathrm{H}-1,98.0$ & 0.98 & 0.01 & 0.11 & 0.069 & 0.712 & 1.626 & 0.699 & 10.158 \\
\hline $1 \mathrm{H}-2,108.0$ & 2.48 & BD & $\mathrm{BD}$ & 0.006 & 0.067 & 0.989 & 0.067 & 11.050 \\
\hline $1 \mathrm{H}-3,80.0$ & 3.61 & $\mathrm{BD}$ & $\mathrm{BD}$ & $\mathrm{BD}$ & 0.058 & 0.12 & 0.058 & NA \\
\hline $1 \mathrm{H}-4,80.0$ & 5.03 & BD & $\mathrm{BD}$ & BD & 0.075 & 0.26 & 0.075 & NA \\
\hline $2 \mathrm{H}-1,30.0$ & 6.80 & 0.00 & 0.03 & 0.006 & 0.076 & 2.563 & 0.072 & 11.841 \\
\hline $2 \mathrm{H}-2,30.0$ & 8.18 & 0.002 & 0.013 & 0.009 & 0.137 & 3.771 & 0.136 & 14.351 \\
\hline $2 \mathrm{H}-3,37.0$ & 9.66 & BD & $\mathrm{BD}$ & 0.016 & 0.285 & 5.429 & 0.285 & 18.369 \\
\hline $2 \mathrm{H}-3,115.0$ & 10.44 & 0.001 & 0.01 & 0.013 & 0.156 & 8.132 & 0.155 & 12.389 \\
\hline $2 \mathrm{H}-3,132.5$ & 10.62 & 0.001 & 0.01 & 0.029 & 0.116 & 4.092 & 0.114 & 3.950 \\
\hline $2 \mathrm{H}-5,20.0$ & 12.20 & BD & $\mathrm{BD}$ & 0.010 & 0.110 & 3.850 & 0.110 & 11.234 \\
\hline $2 \mathrm{H}-6,60.0$ & 13.21 & $\mathrm{BD}$ & BD & 0.035 & 0.087 & 4.044 & 0.087 & 2.515 \\
\hline $2 \mathrm{H}-7,50.0$ & 14.10 & $\mathrm{BD}$ & $\mathrm{BD}$ & 0.028 & 0.114 & 15.739 & 0.114 & 4.041 \\
\hline $2 \mathrm{H}-8,30.0$ & 14.91 & BD & BD & 0.023 & 0.070 & 5.830 & 0.070 & 2.967 \\
\hline \multicolumn{9}{|l|}{ 331-C0014E- } \\
\hline $1 \mathrm{H}-2,40.0$ & 16.56 & 0.001 & 0.006 & 0.013 & 0.045 & 3.093 & 0.044 & 3.570 \\
\hline $1 \mathrm{H}-3,134.0$ & 18.91 & BD & $\mathrm{BD}$ & 0.021 & 0.084 & 3.395 & 0.084 & 4.002 \\
\hline $1 \mathrm{H}-4,125.0$ & 20.22 & $\mathrm{BD}$ & 0.001 & 0.009 & 0.021 & 4.861 & 0.021 & 2.353 \\
\hline $1 \mathrm{H}-5,80.0$ & 21.18 & $\mathrm{BD}$ & $\mathrm{BD}$ & 0.016 & 0.033 & 4.854 & 0.033 & 2.035 \\
\hline $1 \mathrm{H}-6,30.0$ & 21.66 & $\mathrm{BD}$ & BD & 0.015 & 0.065 & 3.682 & 0.065 & 4.169 \\
\hline
\end{tabular}


Table T12 (continued). (Continued on next page.)

\begin{tabular}{|c|c|c|c|c|c|c|c|c|}
\hline $\begin{array}{l}\text { Core, section, } \\
\text { interval }(\mathrm{cm})\end{array}$ & $\begin{array}{l}\text { Depth } \\
\text { (mbsf) }\end{array}$ & $\begin{array}{c}\text { IC } \\
\text { (wt\%) }\end{array}$ & $\begin{array}{l}\mathrm{CaCO}_{3} \\
\text { (wt\%) }\end{array}$ & $\begin{array}{c}\mathrm{TN} \\
\text { (wt\%) }\end{array}$ & $\begin{array}{c}\text { TC } \\
\text { (wt\%) }\end{array}$ & $\begin{array}{c}\text { TS } \\
\text { (wt\%) }\end{array}$ & $\begin{array}{c}\text { TOC } \\
\text { (wt\%) }\end{array}$ & TOC/TN \\
\hline $1 \mathrm{H}-7,75.0$ & 23.44 & $\mathrm{BD}$ & $\mathrm{BD}$ & 0.023 & 0.057 & 3.993 & 0.057 & 2.502 \\
\hline $1 \mathrm{H}-8,40.0$ & 23.94 & $\mathrm{BD}$ & 0.002 & 0.021 & 0.041 & 7.058 & 0.041 & 1.931 \\
\hline $1 \mathrm{H}-9,20.0$ & 24.27 & $\mathrm{BD}$ & $\mathrm{BD}$ & 0.033 & 0.162 & 5.606 & 0.162 & 4.846 \\
\hline $2 \mathrm{H}-1,92.0$ & 26.42 & 0.509 & 4.237 & 0.011 & 0.021 & 2.993 & $\mathrm{BD}$ & 1.919 \\
\hline $2 \mathrm{H}-4,85.0$ & 28.00 & 0.682 & 5.682 & 0.009 & 0.074 & 4.862 & $\mathrm{BD}$ & 8.329 \\
\hline $2 \mathrm{H}-5,123.0$ & 29.78 & 0.010 & 0.084 & 0.007 & 0.028 & 2.753 & 0.018 & 4.044 \\
\hline $2 \mathrm{H}-6,107.0$ & 31.03 & 0.002 & 0.013 & 0.011 & 0.022 & 2.657 & 0.020 & 1.919 \\
\hline $2 \mathrm{H}-7,44.0$ & 31.81 & 0.037 & 0.308 & 0.008 & 0.070 & 8.597 & 0.033 & 8.329 \\
\hline $2 \mathrm{H}-8,110.0$ & 33.88 & $\mathrm{BD}$ & 0.003 & 0.018 & 0.046 & 4.770 & 0.046 & 2.538 \\
\hline \multicolumn{9}{|l|}{ 331-C0014F- } \\
\hline $1 \mathrm{H}-1,5.0$ & 0.05 & 3.167 & 26.387 & 0.04 & 3.48 & 0.06 & 0.309 & 90.187 \\
\hline $1 \mathrm{H}-2,80.0$ & 1.01 & 0.869 & 7.240 & 0.09 & 1.63 & 1.458 & 0.760 & 18.747 \\
\hline $1 \mathrm{H}-4,64.0$ & 2.86 & 0.003 & 0.021 & 0.036 & 0.484 & 1.857 & 0.481 & 13.607 \\
\hline $1 \mathrm{H}-5,78.0$ & 4.01 & 0.004 & 0.029 & 0.009 & 0.096 & 1.224 & 0.092 & 10.952 \\
\hline \multicolumn{9}{|l|}{ 331-C0014G- } \\
\hline $1 \mathrm{H}-1,0.0$ & 0.00 & 0.467 & 3.893 & 0.393 & 1.236 & 0.68 & 0.769 & 1.955 \\
\hline $1 \mathrm{H}-2,20.0$ & 1.62 & 0.826 & 6.886 & 0.595 & 1.549 & 1.63 & 0.723 & 1.214 \\
\hline $1 \mathrm{H}-3,120.0$ & 4.03 & 0.024 & 0.200 & 0.564 & 0.745 & 1.42 & 0.721 & 1.280 \\
\hline $1 \mathrm{H}-5,10.0$ & 5.74 & 0.005 & 0.043 & 0.060 & 0.143 & 1.90 & 0.138 & 2.313 \\
\hline $1 \mathrm{H}-6,36.0$ & 7.41 & 0.004 & 0.036 & $\mathrm{BD}$ & 0.039 & 0.23 & 0.034 & NA \\
\hline $1 \mathrm{H}-7,48.0$ & 8.94 & 0.002 & 0.015 & $\mathrm{BD}$ & 0.037 & 0.30 & 0.035 & NA \\
\hline $2 \mathrm{H}-1,42.0$ & 9.62 & 0.034 & 0.280 & 0.010 & 0.131 & 0.655 & 0.097 & 9.325 \\
\hline $2 \mathrm{H}-2,37.5$ & 10.96 & 0.002 & 0.016 & 0.009 & 0.097 & 1.736 & 0.095 & 10.123 \\
\hline $2 \mathrm{H}-4,88.0$ & 14.27 & 0.003 & 0.025 & 0.035 & 0.097 & 1.561 & 0.094 & 2.683 \\
\hline $2 \mathrm{H}-4,115.0$ & 14.54 & 0.004 & 0.033 & $\mathrm{BD}$ & 0.039 & 1.781 & 0.035 & NA \\
\hline $2 \mathrm{H}-5,45.0$ & 15.25 & 0.003 & 0.028 & 0.022 & 0.087 & 4.193 & 0.084 & 3.817 \\
\hline $2 \mathrm{H}-6,26.0$ & 16.48 & 0.001 & 0.004 & 0.018 & 0.152 & 3.050 & 0.151 & 8.407 \\
\hline $2 \mathrm{H}-7,80.0$ & 18.46 & 0.002 & 0.017 & 0.576 & 0.411 & 3.472 & 0.409 & 0.711 \\
\hline $3 \mathrm{H}-1,8.0$ & 18.78 & 0.233 & 1.937 & 0.007 & 0.519 & 3.830 & 0.286 & 38.326 \\
\hline $3 \mathrm{H}-2,26.0$ & 19.60 & 0.005 & 0.041 & 0.008 & 0.077 & 6.434 & 0.072 & 9.376 \\
\hline $3 \mathrm{H}-3,30.0$ & 21.05 & 0.003 & 0.025 & 0.035 & 0.073 & 3.696 & 0.070 & 2.026 \\
\hline $3 \mathrm{H}-4,28.5$ & 21.46 & 0.003 & 0.028 & 0.035 & 0.080 & 5.777 & 0.077 & 2.201 \\
\hline $3 \mathrm{H}-4,96.0$ & 22.13 & 0.003 & 0.025 & 0.006 & 0.026 & 2.979 & 0.023 & 3.787 \\
\hline $3 \mathrm{H}-5,27.0$ & 22.85 & 0.003 & 0.024 & 0.030 & 0.054 & 4.337 & 0.051 & 1.704 \\
\hline $3 \mathrm{H}-5,83.0$ & 23.41 & 0.003 & 0.023 & 0.006 & 0.024 & 5.443 & 0.021 & 3.291 \\
\hline $3 \mathrm{H}-7,50.0$ & 24.97 & 3.972 & 33.096 & $\mathrm{BD}$ & 4.104 & 1.994 & 0.133 & NA \\
\hline $3 \mathrm{H}-8,116.0$ & 26.36 & 0.010 & 0.087 & 0.015 & 0.123 & 2.905 & 0.113 & 7.381 \\
\hline $3 \mathrm{H}-9,85.0$ & 27.51 & 0.012 & 0.103 & $\mathrm{BD}$ & 0.197 & 7.650 & 0.184 & NA \\
\hline $3 \mathrm{H}-10,40.0$ & 28.07 & 0.040 & 0.333 & 0.016 & 0.285 & 3.241 & 0.245 & 15.363 \\
\hline $4 \mathrm{H}-1,47.0$ & 28.67 & 0.982 & 8.181 & $\mathrm{BD}$ & 1.242 & 4.838 & 0.261 & NA \\
\hline $3 \mathrm{H}-\mathrm{CC}, 70.0$ & 28.91 & 2.115 & 17.622 & 0.014 & 2.388 & 2.836 & 0.273 & 19.068 \\
\hline $4 \mathrm{H}-5,0.0$ & 30.41 & 0.006 & 0.047 & 0.000 & 0.024 & 5.260 & 0.018 & NA \\
\hline $4 \mathrm{H}-6,80.0$ & 32.22 & 0.042 & 0.346 & 0.005 & 0.127 & 8.433 & 0.086 & 16.834 \\
\hline $4 \mathrm{H}-7,70.0$ & 33.13 & 0.005 & 0.043 & $\mathrm{BD}$ & 0.014 & 1.921 & 0.009 & NA \\
\hline $4 \mathrm{H}-8,91.0$ & 34.34 & 0.002 & 0.018 & $\mathrm{BD}$ & 0.013 & 1.279 & 0.011 & NA \\
\hline $4 \mathrm{H}-10,60.0$ & 36.05 & 0.006 & 0.048 & 0.000 & 0.015 & 6.604 & 0.010 & NA \\
\hline $4 \mathrm{H}-\mathrm{CC}, 14.0$ & 37.60 & 0.041 & 0.339 & 0.009 & 0.060 & 2.742 & 0.019 & 2.165 \\
\hline $5 \mathrm{H}-3,45.0$ & 38.49 & 0.000 & BD & $\mathrm{BD}$ & 0.016 & 7.938 & 0.016 & NA \\
\hline $5 \mathrm{H}-4,30.0$ & 38.90 & 0.000 & $\mathrm{BD}$ & 0.018 & 0.020 & 14.040 & 0.020 & 1.089 \\
\hline $5 \mathrm{H}-5,68.0$ & 39.63 & 0.012 & 0.097 & 0.018 & 0.015 & 5.694 & 0.004 & 0.191 \\
\hline $6 \mathrm{H}-2,38.0$ & 47.72 & 0.023 & 0.193 & 0.013 & 0.033 & 2.812 & 0.010 & 0.787 \\
\hline $6 \mathrm{H}-3,80.0$ & 49.14 & 0.000 & $\mathrm{BD}$ & 0.009 & 0.009 & 3.207 & 0.009 & 0.937 \\
\hline $6 \mathrm{H}-\mathrm{CC}, 10.0$ & 50.27 & 0.000 & $\mathrm{BD}$ & 0.011 & 0.011 & 4.097 & 0.011 & 1.058 \\
\hline $6 \mathrm{H}-5,67.0$ & 50.36 & 0.001 & 0.008 & 0.007 & 0.006 & 1.601 & 0.005 & 0.651 \\
\hline $8 \mathrm{H}-\mathrm{CC}, 6.0$ & 53.57 & 0.096 & 0.801 & 0.007 & 0.116 & 3.078 & 0.020 & 2.775 \\
\hline $9 X-1,14.0$ & 54.34 & $\mathrm{BD}$ & 0.002 & 0.01 & 0.02 & 2.476 & 0.015 & 1.661 \\
\hline $9 X-2,64.0$ & 56.25 & $\mathrm{BD}$ & $\mathrm{BD}$ & 0.014 & 0.008 & 2.051 & 0.008 & 0.593 \\
\hline $9 X-C C, 27.0$ & 57.16 & $\mathrm{BD}$ & BD & $\mathrm{BD}$ & 0.007 & 1.885 & 0.007 & NA \\
\hline $10 \mathrm{H}-\mathrm{CC}, 5.0$ & 59.50 & $\mathrm{BD}$ & $\mathrm{BD}$ & 0.006 & 0.007 & 1.499 & 0.007 & 1.039 \\
\hline $11 X-1,3.0$ & 59.73 & 0.001 & 0.005 & 0.006 & 0.011 & 1.495 & 0.010 & 1.760 \\
\hline $11 \mathrm{X}-\mathrm{CC}, 30.0$ & 60.12 & 0.000 & 0.000 & 0.008 & 0.009 & 2.955 & 0.009 & 1.131 \\
\hline $12 \mathrm{H}-2,74.0$ & 65.07 & 0.002 & 0.021 & 0.015 & 0.007 & 6.507 & 0.004 & 0.266 \\
\hline $13 \mathrm{~T}-1,28.0$ & 66.98 & $\mathrm{BD}$ & $\mathrm{BD}$ & 0.010 & 0.007 & 2.788 & 0.007 & 0.655 \\
\hline $13 \mathrm{~T}-2,79.5$ & 68.50 & $\mathrm{BD}$ & $\mathrm{BD}$ & 0.016 & 0.006 & 2.513 & 0.006 & 0.396 \\
\hline $13 \mathrm{~T}-3,59.0$ & 69.30 & $\mathrm{BD}$ & $\mathrm{BD}$ & 0.013 & 0.047 & 2.442 & 0.047 & 3.592 \\
\hline $13 \mathrm{~T}-4,22.0$ & 69.93 & 0.001 & 0.011 & 0.013 & 0.008 & 1.782 & 0.007 & 0.531 \\
\hline 14T-1, 18.0 & 71.38 & 0.002 & 0.015 & $\mathrm{BD}$ & 0.016 & 1.858 & 0.015 & NA \\
\hline 14T-2, 51.0 & 72.19 & $\mathrm{BD}$ & 0.000 & 0.013 & 0.008 & 3.016 & 0.008 & 0.653 \\
\hline
\end{tabular}


Table T12 (continued).

\begin{tabular}{|c|c|c|c|c|c|c|c|c|}
\hline $\begin{array}{l}\text { Core, section, } \\
\text { interval }(\mathrm{cm})\end{array}$ & $\begin{array}{l}\text { Depth } \\
\text { (mbsf) }\end{array}$ & $\begin{array}{c}\text { IC } \\
(w t \%)\end{array}$ & $\begin{array}{l}\mathrm{CaCO}_{3} \\
\text { (wt\%) }\end{array}$ & $\begin{array}{c}\mathrm{TN} \\
(\mathrm{wt} \%)\end{array}$ & $\begin{array}{c}\text { TC } \\
\text { (wt\%) }\end{array}$ & $\begin{array}{c}\text { TS } \\
\text { (wt\%) }\end{array}$ & $\begin{array}{l}\text { TOC } \\
\text { (wt\%) }\end{array}$ & $\mathrm{TOC} / \mathrm{TN}$ \\
\hline $14 \mathrm{~T}-3,42.0$ & 73.11 & 0.002 & 0.017 & $\mathrm{BD}$ & 0.006 & 3.495 & 0.004 & NA \\
\hline $16 \mathrm{~T}-1,7.0$ & 75.97 & $\mathrm{BD}$ & $\mathrm{BD}$ & 0.020 & 0.009 & 2.880 & 0.009 & 0.458 \\
\hline 15T-CC, 17.0 & 76.08 & $\mathrm{BD}$ & $\mathrm{BD}$ & 0.016 & 0.010 & 2.904 & 0.010 & 0.588 \\
\hline $16 \mathrm{~T}-2,10.0$ & 76.79 & $\mathrm{BD}$ & $\mathrm{BD}$ & 0.031 & 0.008 & 3.663 & 0.008 & 0.271 \\
\hline 17T-1, 34.0 & 80.54 & $\mathrm{BD}$ & $\mathrm{BD}$ & 0.030 & 0.008 & 2.696 & 0.008 & 0.273 \\
\hline $17 \mathrm{~T}-2,20.0$ & 80.81 & $\mathrm{BD}$ & $\mathrm{BD}$ & 0.039 & 0.009 & 2.096 & 0.009 & 0.238 \\
\hline $17 \mathrm{~T}-3,40.0$ & 82.02 & $\mathrm{BD}$ & $\mathrm{BD}$ & 0.031 & 0.008 & 3.325 & 0.008 & 0.268 \\
\hline $17 \mathrm{~T}-4,40.0$ & 83.03 & $\mathrm{BD}$ & $\mathrm{BD}$ & 0.060 & 0.010 & 5.322 & 0.010 & 0.169 \\
\hline $18 \mathrm{~T}-2,34.0$ & 85.36 & $\mathrm{BD}$ & $\mathrm{BD}$ & 0.026 & 0.010 & 3.482 & 0.010 & 0.382 \\
\hline $18 \mathrm{~T}-3,83.0$ & 86.85 & $\mathrm{BD}$ & $\mathrm{BD}$ & 0.009 & 0.008 & 4.767 & 0.008 & 0.957 \\
\hline 18T-CC, 12.0 & 88.15 & 0.006 & 0.053 & $\mathrm{BD}$ & 0.012 & 0.707 & 0.005 & NA \\
\hline 19T-CC, 15.0 & 89.51 & $\mathrm{BD}$ & $\mathrm{BD}$ & 0.010 & 0.005 & 1.373 & 0.005 & 0.478 \\
\hline 20T-1, 30.0 & 94.00 & 0.004 & 0.033 & 0.013 & 0.008 & 0.56 & 0.004 & 0.330 \\
\hline 20T-CC, 36.5 & 94.70 & $\mathrm{BD}$ & $\mathrm{BD}$ & $\mathrm{BD}$ & 0.006 & 0.21 & 0.006 & NA \\
\hline $21 \mathrm{H}-2,74.0$ & 99.04 & 0.004 & 0.036 & 0.036 & 0.011 & 1.938 & 0.007 & 0.182 \\
\hline $21 \mathrm{H}-3,79.0$ & 99.90 & 0.010 & 0.08 & 0.032 & 0.007 & 2.409 & $\mathrm{BD}$ & NA \\
\hline $22 X-1,7.0$ & 100.27 & $\mathrm{BD}$ & 0.002 & 0.012 & 0.008 & 1.156 & 0.008 & 0.613 \\
\hline $22 \mathrm{X}-\mathrm{CC}, 3.0$ & 100.59 & $\mathrm{BD}$ & $\mathrm{BD}$ & 0.043 & 0.007 & 6.418 & 0.007 & 0.168 \\
\hline $22 \mathrm{X}-\mathrm{CC}, 10.0$ & 100.66 & 0.004 & 0.029 & 0.336 & 0.101 & 2.117 & 0.098 & 0.291 \\
\hline $23 X-1,5.0$ & 104.75 & $\mathrm{BD}$ & $\mathrm{BD}$ & 0.033 & 0.007 & 1.462 & 0.007 & 0.218 \\
\hline $23 X-2,13.0$ & 105.44 & 0.001 & 0.008 & 0.027 & 0.006 & 1.297 & 0.005 & 0.178 \\
\hline $24 \mathrm{~T}-1,11.0$ & 109.31 & 0.001 & 0.004 & 0.009 & 0.006 & 0.45 & 0.006 & 0.657 \\
\hline $24 \mathrm{~T}-1,22.0$ & 109.42 & 0.005 & 0.042 & 0.370 & 0.006 & 1.775 & 0.001 & 0.004 \\
\hline 24T-2, 90.0 & 110.60 & $\mathrm{BD}$ & $\mathrm{BD}$ & 0.02 & 0.03 & 1.548 & 0.034 & NA \\
\hline $24 \mathrm{~T}-3,55.0$ & 111.25 & 0.003 & 0.028 & 0.014 & 0.005 & 1.638 & 0.001 & 0.106 \\
\hline $24 \mathrm{~T}-4,49.5$ & 112.18 & $\mathrm{BD}$ & $\mathrm{BD}$ & 0.018 & 0.006 & 1.251 & 0.006 & 0.306 \\
\hline $24 \mathrm{~T}-\mathrm{CC}, 40.0$ & 113.19 & $\mathrm{BD}$ & $\mathrm{BD}$ & $\mathrm{BD}$ & 0.007 & 0.727 & 0.007 & NA \\
\hline $25 \mathrm{~T}-1,28.5$ & 113.99 & $B D$ & $\mathrm{BD}$ & 0.016 & 0.011 & 0.938 & 0.011 & 0.704 \\
\hline $25 \mathrm{~T}-\mathrm{CC}, 0.0$ & 114.33 & $\mathrm{BD}$ & $\mathrm{BD}$ & 0.013 & 0.006 & 0.73 & 0.006 & 0.450 \\
\hline 26T-CC, 0.0 & 118.20 & $\mathrm{BD}$ & $\mathrm{BD}$ & 0.014 & 0.012 & 1.450 & 0.012 & 0.913 \\
\hline $30 X-1,10.0$ & 127.30 & $\mathrm{BD}$ & $\mathrm{BD}$ & $\mathrm{BD}$ & 0.01 & 0.22 & 0.006 & NA \\
\hline
\end{tabular}

$\mathrm{IC}=$ inorganic carbon, $\mathrm{TN}=$ total nitrogen, $\mathrm{TC}=$ total carbon, $\mathrm{TS}=$ total sulfur, $\mathrm{TOC}=$ total organic carbon. $\mathrm{BD}=$ below detection, $\mathrm{NA}=$ not applicable. 
Table T13. Results of direct cell counting, Site C0014.

\begin{tabular}{|c|c|c|}
\hline Core, section & $\begin{array}{l}\text { Depth } \\
\text { (mbsf) }\end{array}$ & $\begin{array}{l}\text { Cells } / \mathrm{mL} \\
\text { sediment }\end{array}$ \\
\hline \multicolumn{3}{|l|}{ 331-C0014B- } \\
\hline $1 \mathrm{H}-1$ & 0.326 & $1.78 \mathrm{E}+07$ \\
\hline $1 \mathrm{H}-1$ & 1.138 & $1.02 \mathrm{E}+07$ \\
\hline $1 \mathrm{H}-2$ & 2.35 & $1.74 \mathrm{E}+06$ \\
\hline $1 \mathrm{H}-3$ & 3.6 & ND \\
\hline $1 \mathrm{H}-4$ & 4.971 & ND \\
\hline $1 \mathrm{H}-5$ & 5.959 & ND \\
\hline $2 \mathrm{H}-3$ & 8.536 & ND \\
\hline $2 \mathrm{H}-7$ & 12.232 & ND \\
\hline $2 \mathrm{H}-10$ & 14.327 & $3.78 \mathrm{E}+06$ \\
\hline $3 \mathrm{H}-2$ & 17.206 & ND \\
\hline $3 \mathrm{H}-5$ & 19.185 & ND \\
\hline $3 \mathrm{H}-7$ & 21.671 & ND \\
\hline $3 \mathrm{H}-9$ & 23.236 & ND \\
\hline $4 \mathrm{H}-2$ & 26.213 & ND \\
\hline $4 \mathrm{H}-3$ & 27.495 & ND \\
\hline $4 \mathrm{H}-4$ & 28.838 & ND \\
\hline $4 \mathrm{H}-6$ & 31.066 & ND \\
\hline $4 \mathrm{H}-7$ & 32.623 & ND \\
\hline $5 \mathrm{H}-12$ & 40.609 & ND \\
\hline $5 \mathrm{H}-15$ & 43.78 & ND \\
\hline \multicolumn{3}{|l|}{ 331-C0014D- } \\
\hline $1 \mathrm{H}-1$ & 0.23 & $4.72 \mathrm{E}+08$ \\
\hline $1 \mathrm{H}-2$ & 1.97 & $4.11 \mathrm{E}+07$ \\
\hline $1 \mathrm{H}-3$ & 3.075 & $3.01 \mathrm{E}+06$ \\
\hline $1 \mathrm{H}-4$ & 4.225 & $1.87 \mathrm{E}+06$ \\
\hline $2 \mathrm{H}-1$ & 6.67 & $1.55 \mathrm{E}+06$ \\
\hline $2 \mathrm{H}-2$ & 8.63 & $8.94 \mathrm{E}+06$ \\
\hline $2 \mathrm{H}-3$ & 10.17 & $2.81 \mathrm{E}+06$ \\
\hline $2 \mathrm{H}-4$ & 11.38 & ND \\
\hline $2 \mathrm{H}-6$ & 12.795 & ND \\
\hline \multicolumn{3}{|l|}{ 331-C0014E- } \\
\hline $1 \mathrm{H}-3$ & 18.515 & ND \\
\hline $1 \mathrm{H}-4$ & 19.67 & ND \\
\hline $1 \mathrm{H}-5$ & 20.69 & ND \\
\hline $1 \mathrm{H}-6$ & 22.06 & $3.70 \mathrm{E}+06$ \\
\hline $1 \mathrm{H}-9$ & 24.385 & ND \\
\hline $2 \mathrm{H}-4$ & 27.395 & ND \\
\hline $2 \mathrm{H}-5$ & 29.145 & ND \\
\hline $2 \mathrm{H}-6$ & 30.805 & ND \\
\hline $2 \mathrm{H}-8$ & 33.33 & ND \\
\hline \multicolumn{3}{|l|}{ 331-C0014G- } \\
\hline $1 \mathrm{H}-1$ & 0.271 & $3.28 \mathrm{E}+07$ \\
\hline $1 \mathrm{H}-2$ & 1.811 & $3.74 \mathrm{E}+06$ \\
\hline $1 \mathrm{H}-3$ & 3.709 & $1.31 \mathrm{E}+06$ \\
\hline $1 \mathrm{H}-4$ & 4.092 & ND \\
\hline $1 \mathrm{H}-5$ & 5.869 & ND \\
\hline $2 \mathrm{H}-5$ & 15.828 & ND \\
\hline $2 \mathrm{H}-7$ & 17.648 & ND \\
\hline $3 \mathrm{H}-2$ & 19.889 & ND \\
\hline $6 \mathrm{H}-3$ & 47.791 & ND \\
\hline $12 \mathrm{H}-3$ & 65.4 & ND \\
\hline $14 \mathrm{~T}-2$ & 71.675 & ND \\
\hline $24 \mathrm{~T}-2$ & 110.09 & ND \\
\hline
\end{tabular}

ND = not detected (see Expedition 331 Scientists, 2011b). 
Table T14. Cultivation experiment results for putative iron-oxidizers, Site C0014.

\begin{tabular}{|c|c|c|c|c|c|}
\hline \multicolumn{2}{|c|}{ Depth (mbsf) } & \multirow{2}{*}{$\begin{array}{l}\text { Hole, core, section, } \\
\text { interval }(\mathrm{cm})\end{array}$} & \multirow{2}{*}{$\begin{array}{l}\text { Cultivation } \\
\text { time (days) }\end{array}$} & \multicolumn{2}{|c|}{ Growth media } \\
\hline Top & Bottom & & & ASW A & ASW B \\
\hline & & $331-$ & & & \\
\hline 0.23 & 0.38 & C0014D-1H-1, 23-38 & $5-6$ & - & ND \\
\hline 0.27 & 0.39 & C0014G-1H-1, 28-40 & 4.5 & ++ & ++ \\
\hline 0.33 & 0.42 & C0014B-1H-1, 35-45 & $5-6$ & +++ & ND \\
\hline 1.81 & 1.93 & C0014G-1H-2, 45-57 & 4.5 & + & ND \\
\hline 2.35 & 2.44 & C0014B-1H-2, 110-120 & $5-6$ & - & ND \\
\hline 8.54 & 8.67 & C0014B-2H-3, 20-35 & 6 & - & - \\
\hline 8.63 & 8.83 & C0014D-2H-2, 75-95 & $5-6$ & - & ND \\
\hline 12.23 & 12.41 & C0014B-2H-7, 50-70 & 6 & - & ND \\
\hline 18.52 & 18.67 & C0014E-1H-3, 95-110 & 6 & - & - \\
\hline 19.67 & 19.87 & C0014E-1H-4, 70-90 & $5-6$ & - & ND \\
\hline 20.69 & 20.84 & C0014E-1H-5, 31-46 & 6 & - & ND \\
\hline 21.67 & 21.84 & C0014B-3H-7, 99-119 & 6 & - & - \\
\hline 27.40 & 27.55 & C0014E-2H-4, 25-40 & 6 & - & - \\
\hline 42.31 & 42.45 & C0014B-5H-14, 33-48 & 6 & - & - \\
\hline
\end{tabular}

$+++=$ good growth (lots of cells) $++=$ medium growth,$+=$ little growth $($ f few cells $),-=$ no growth. ND = no data. 
Table T15. Results of contamination tests using fluorescent microspheres, Site C0014.

\begin{tabular}{|c|c|c|c|}
\hline \multirow[b]{2}{*}{ Core, section } & \multirow{2}{*}{$\begin{array}{l}\text { Depth } \\
\text { (mbsf) }\end{array}$} & \multicolumn{2}{|c|}{ Spheres $/ \mathrm{mL}$ sediment } \\
\hline & & Interior & Outer edge \\
\hline \multicolumn{4}{|l|}{ 331-C0014B- } \\
\hline $1 \mathrm{H}-1$ & 0.326 & ND & ND \\
\hline $1 \mathrm{H}-1$ & 1.138 & ND & ND \\
\hline $1 \mathrm{H}-2$ & 2.35 & ND & ND \\
\hline $2 \mathrm{H}-3$ & 8.536 & ND & $3.64 \mathrm{E}+04$ \\
\hline $2 \mathrm{H}-7$ & 12.232 & $1.82 \mathrm{E}+02$ & ND \\
\hline $2 \mathrm{H}-10$ & 14.327 & ND & $6.29 \mathrm{E}+03$ \\
\hline $3 \mathrm{H}-5$ & 19.185 & ND & ND \\
\hline $4 \mathrm{H}-2$ & 26.213 & ND & $5.81 E+02$ \\
\hline $4 \mathrm{H}-6$ & 31.066 & ND & ND \\
\hline $5 \mathrm{H}-12$ & 40.609 & ND & ND \\
\hline \multicolumn{4}{|l|}{ 331-C0014D- } \\
\hline $1 \mathrm{H}-1$ & 0.23 & ND & ND \\
\hline $1 \mathrm{H}-2$ & 1.97 & ND & $3.63 \mathrm{E}+02$ \\
\hline $1 \mathrm{H}-3$ & 3.075 & ND & ND \\
\hline $1 \mathrm{H}-4$ & 4.225 & ND & $5.48 \mathrm{E}+02$ \\
\hline $2 \mathrm{H}-1$ & 6.67 & $1.43 \mathrm{E}+04$ & $7.75 \mathrm{E}+03$ \\
\hline $2 \mathrm{H}-2$ & 8.63 & ND & ND \\
\hline $2 \mathrm{H}-3$ & 10.17 & ND & $3.87 \mathrm{E}+02$ \\
\hline $2 \mathrm{H}-4$ & 11.38 & ND & $1.45 \mathrm{E}+02$ \\
\hline $2 \mathrm{H}-6$ & 12.795 & ND & $1.21 \mathrm{E}+03$ \\
\hline \multicolumn{4}{|l|}{ 331-C0014E- } \\
\hline $1 \mathrm{H}-3$ & 18.515 & ND & $9.37 E+03$ \\
\hline $1 \mathrm{H}-5$ & 20.69 & ND & ND \\
\hline $1 \mathrm{H}-6$ & 22.06 & ND & NT \\
\hline $2 \mathrm{H}-4$ & 27.395 & ND & ND \\
\hline $2 \mathrm{H}-7$ & 32.02 & ND & ND \\
\hline $2 \mathrm{H}-8$ & 33.33 & ND & ND \\
\hline \multicolumn{4}{|l|}{ 331-C0014G- } \\
\hline $1 \mathrm{H}-1$ & 0.271 & ND & ND \\
\hline $1 \mathrm{H}-2$ & 1.811 & ND & ND \\
\hline $1 \mathrm{H}-3$ & 3.709 & $1.94 \mathrm{E}+02$ & $2.52 E+03$ \\
\hline $1 \mathrm{H}-4$ & 4.092 & ND & ND \\
\hline $1 \mathrm{H}-6$ & 7.844 & $2.91 \mathrm{E}+02$ & ND \\
\hline $2 \mathrm{H}-5$ & 15.828 & ND & $1.45 \mathrm{E}+02$ \\
\hline $3 \mathrm{H}-5$ & 22.708 & ND & ND \\
\hline $4 \mathrm{H}-2$ & 29.155 & ND & ND \\
\hline $4 \mathrm{H}-9$ & 34.645 & $3.99 \mathrm{E}+03$ & $3.27 \mathrm{E}+03$ \\
\hline $4 \mathrm{H}-11$ & 37.105 & ND & $1.45 \mathrm{E}+03$ \\
\hline $5 \mathrm{H}-3$ & 38.145 & ND & ND \\
\hline $6 \mathrm{H}-2$ & 47.577 & ND & ND \\
\hline $12 \mathrm{H}-3$ & 65.4 & ND & ND \\
\hline
\end{tabular}

ND $=$ not detected, $\mathrm{NT}=$ not tested 
Table T16. Results of contamination tests using perfluorocarbon tracer (PFT), Site C0014.

\begin{tabular}{|c|c|c|c|c|c|c|c|}
\hline \multirow[b]{2}{*}{ Core, section } & \multirow{2}{*}{$\begin{array}{l}\text { Depth } \\
\text { (mbsf) }\end{array}$} & \multicolumn{2}{|c|}{$\begin{array}{l}\text { PFT in test vial gas phase } \\
(\mathrm{ppm})\end{array}$} & \multicolumn{2}{|c|}{$\begin{array}{l}\text { Sample weight } \\
\text { in test vial }(\mathrm{g})\end{array}$} & \multicolumn{2}{|c|}{$\begin{array}{c}\text { PFT per g sample } \\
(\mathrm{ppm})\end{array}$} \\
\hline & & Interior & Outer edge & Interior & Outer edge & Interior & Outer edge \\
\hline \multicolumn{8}{|l|}{ 331-C0014B- } \\
\hline $1 \mathrm{H}-1$ & 1.138 & $9.50 \mathrm{E}-03$ & 4.67E-02 & 2.17 & 2.12 & $4.38 \mathrm{E}-03$ & $2.20 \mathrm{E}-02$ \\
\hline $1 \mathrm{H}-2$ & 2.35 & ND & $1.32 \mathrm{E}-02$ & 2.60 & 2.57 & ND & $5.14 \mathrm{E}-03$ \\
\hline $2 \mathrm{H}-3$ & 8.536 & ND & $9.97 \mathrm{E}-02$ & 2.04 & 3.99 & ND & $2.50 \mathrm{E}-02$ \\
\hline $2 \mathrm{H}-10$ & 14.327 & ND & 1.07E-02 & 3.15 & 2.84 & ND & $3.77 \mathrm{E}-03$ \\
\hline $3 \mathrm{H}-5$ & 19.185 & $2.20 \mathrm{E}-03$ & 1.37E-01 & 3.37 & 3.81 & $6.53 \mathrm{E}-04$ & $3.60 \mathrm{E}-02$ \\
\hline $3 \mathrm{H}-9$ & 23.236 & $1.29 \mathrm{E}-03$ & $1.82 \mathrm{E}-02$ & 2.85 & 3.36 & $4.53 \mathrm{E}-04$ & $5.42 \mathrm{E}-03$ \\
\hline $4 \mathrm{H}-3$ & 27.495 & ND & $7.13 \mathrm{E}-03$ & 2.29 & 3.29 & ND & $2.17 \mathrm{E}-03$ \\
\hline $4 \mathrm{H}-8$ & 33.741 & ND & ND & 3.14 & 1.99 & ND & ND \\
\hline $5 \mathrm{H}-12$ & 40.609 & $4.04 \mathrm{E}-02$ & $1.11 \mathrm{E}+00$ & 2.83 & 3.55 & $1.43 \mathrm{E}-02$ & $3.13 \mathrm{E}-01$ \\
\hline $5 \mathrm{H}-15$ & 43.78 & $2.52 \mathrm{E}+00$ & $2.53 \mathrm{E}+04$ & 2.81 & 3.27 & 8.97E-01 & $7.74 \mathrm{E}+03$ \\
\hline \multicolumn{8}{|l|}{ 331-C0014D- } \\
\hline $1 \mathrm{H}-1$ & 0.23 & ND & ND & 2.88 & 3.28 & ND & ND \\
\hline $1 \mathrm{H}-3$ & 3.075 & $4.20 \mathrm{E}-02$ & $4.06 \mathrm{E}-03$ & 3.79 & 3.75 & $1.11 \mathrm{E}-02$ & $1.08 \mathrm{E}-03$ \\
\hline $1 \mathrm{H}-4$ & 4.225 & $8.03 \mathrm{E}-03$ & $1.86 \mathrm{E}-01$ & 1.61 & 2.33 & $4.99 \mathrm{E}-03$ & $7.98 \mathrm{E}-02$ \\
\hline $2 \mathrm{H}-1$ & 6.67 & $9.23 \mathrm{E}-02$ & $1.31 \mathrm{E}-01$ & 1.87 & 2.48 & $4.94 \mathrm{E}-02$ & $5.28 \mathrm{E}-02$ \\
\hline $2 \mathrm{H}-2$ & 8.63 & $3.00 \mathrm{E}-03$ & $1.51 \mathrm{E}-02$ & 2.51 & 2.07 & $1.20 \mathrm{E}-03$ & $7.29 \mathrm{E}-03$ \\
\hline $2 \mathrm{H}-4$ & 11.38 & ND & $3.22 \mathrm{E}-03$ & 3.37 & 3.51 & ND & $9.17 \mathrm{E}-04$ \\
\hline $2 \mathrm{H}-6$ & 12.795 & ND & $2.24 \mathrm{E}-03$ & 2.65 & 2.73 & ND & $8.21 \mathrm{E}-04$ \\
\hline \multicolumn{8}{|l|}{ 331-C0014E- } \\
\hline $1 \mathrm{H}-4$ & 19.67 & ND & $1.22 \mathrm{E}+02$ & 1.79 & 4.10 & ND & $2.98 \mathrm{E}+01$ \\
\hline $1 \mathrm{H}-6$ & 22.06 & ND & ND & 2.25 & 4.21 & ND & ND \\
\hline $2 \mathrm{H}-6$ & 30.805 & ND & $1.98 \mathrm{E}+02$ & 3.73 & 2.01 & ND & $9.85 \mathrm{E}+01$ \\
\hline $2 \mathrm{H}-8$ & 33.33 & ND & $3.85 \mathrm{E}+02$ & 2.64 & 1.76 & ND & $2.19 \mathrm{E}+02$ \\
\hline \multicolumn{8}{|l|}{ 331-C0014G- } \\
\hline $1 \mathrm{H}-1$ & 0.271 & $1.39 \mathrm{E}-03$ & $1.62 \mathrm{E}+00$ & 2.92 & 3.91 & $4.76 \mathrm{E}-04$ & $4.14 \mathrm{E}-01$ \\
\hline $1 \mathrm{H}-4$ & 4.092 & $2.61 \mathrm{E}-03$ & $3.49 \mathrm{E}-01$ & 3.48 & 3.39 & $7.50 \mathrm{E}-04$ & $1.03 \mathrm{E}-01$ \\
\hline $2 \mathrm{H}-5$ & 15.828 & ND & ND & 3.27 & 3.04 & ND & ND \\
\hline $3 \mathrm{H}-5$ & 22.708 & ND & NT & 2.98 & NT & ND & NT \\
\hline $4 \mathrm{H}-2$ & 29.155 & ND & ND & 2.59 & 1.53 & ND & ND \\
\hline $5 \mathrm{H}-3$ & 38.145 & ND & $2.27 \mathrm{E}-01$ & 2.77 & 3.24 & ND & $7.01 \mathrm{E}-02$ \\
\hline $6 \mathrm{H}-3$ & 47.791 & $1.46 \mathrm{E}-03$ & $5.69 \mathrm{E}-03$ & 3.99 & 3.37 & $3.66 \mathrm{E}-04$ & $1.69 \mathrm{E}-03$ \\
\hline $9 X-2$ & 55.705 & $1.91 \mathrm{E}-02$ & 7.36E-01 & 1.15 & 3.41 & $1.66 \mathrm{E}-02$ & $2.16 \mathrm{E}-01$ \\
\hline $12 \mathrm{H}-3$ & 65.4 & ND & $1.96 \mathrm{E}-03$ & 1.69 & 2.40 & ND & 8.17E-04 \\
\hline $13 \mathrm{~T}-1$ & 67.45 & ND & NT & 2.41 & NT & ND & NT \\
\hline $14 \mathrm{~T}-2$ & 71.675 & $3.33 \mathrm{E}-03$ & $3.93 \mathrm{E}-01$ & 4.76 & 5.07 & $7.00 \mathrm{E}-04$ & $7.75 \mathrm{E}-02$ \\
\hline $16 \mathrm{~T}-1$ & 76.42 & $6.45 \mathrm{E}-03$ & $4.20 \mathrm{E}-03$ & 0.87 & 1.63 & $7.41 \mathrm{E}-03$ & $2.58 \mathrm{E}-03$ \\
\hline 17T-2 & 81.19 & $1.50 \mathrm{E}-03$ & $1.09 \mathrm{E}-02$ & 2.84 & 2.18 & $5.28 \mathrm{E}-04$ & $5.00 \mathrm{E}-03$ \\
\hline
\end{tabular}

$\mathrm{ND}=$ not detected, $\mathrm{NT}=$ not tested

Table T17. Average porosity, bulk density, grain density, thermal conductivity, and formation factor, Site C0014.

\begin{tabular}{cccccc}
\hline Hole & $\begin{array}{c}\text { Porosity } \\
(\%)\end{array}$ & $\begin{array}{c}\text { Bulk density } \\
\left(\mathrm{g} / \mathrm{cm}^{3}\right)\end{array}$ & $\begin{array}{c}\text { Grain density } \\
\left(\mathrm{g} / \mathrm{cm}^{3}\right)\end{array}$ & $\begin{array}{c}\text { Thermal } \\
\text { conductivity } \\
(\mathrm{W} /[\mathrm{m} \cdot \mathrm{K}])\end{array}$ & $\begin{array}{c}\text { Formation } \\
\text { factor }\end{array}$ \\
\hline 331- & & & & & \\
C0014A & $0.72 \pm 0.04$ & $1.48 \pm 0.06$ & $2.65 \pm 0.19$ & $0.85 \pm 0.09$ & $2.90 \pm 1.1$ \\
C0014B & $0.75 \pm 0.07$ & $1.48 \pm 0.11$ & $2.86 \pm 0.17$ & $0.96 \pm 0.22$ & $4.92 \pm 2.5$ \\
C0014C & $0.71 \pm 0.05$ & $1.43 \pm 0.07$ & $2.42 \pm 0.23$ & $0.66 \pm 0.08$ & $3.97 \pm 1.2$ \\
C0014D & $0.76 \pm 0.05$ & $1.41 \pm 0.11$ & $2.64 \pm 0.22$ & $0.64 \pm 0.11$ & $3.66 \pm 0.73$ \\
C0014E & $0.71 \pm 0.12$ & $1.57 \pm 0.18$ & $2.96 \pm 0.30$ & $0.95 \pm 0.19$ & $6.42 \pm 1.2$ \\
C0014F & $0.71 \pm 0.03$ & $1.50 \pm 0.07$ & $2.70 \pm 0.10$ & $0.79 \pm 0.06$ & $2.65 \pm 0.52$ \\
C0014C & $0.62 \pm 0.14$ & $1.70 \pm 0.26$ & $2.82 \pm 0.32$ & $1.30 \pm 0.59$ & $6.00 \pm 3.4$ \\
Average: & $0.71 \pm 0.05$ & $1.51 \pm 0.1$ & $2.72 \pm 0.18$ & $0.88 \pm 0.22$ & $4.36 \pm 1.5$ \\
\hline
\end{tabular}

Error is the standard deviation of the average. 
Table T18. APCT3 temperature measurements, Site C0014.

\begin{tabular}{cccc}
\hline Hole, core & $\begin{array}{c}\text { Depth } \\
\mathrm{CSF}(\mathrm{m})\end{array}$ & $\begin{array}{c}\text { Bottom water } \\
\text { temperature } \\
\left({ }^{\circ} \mathrm{C}\right)\end{array}$ & $\begin{array}{c}\text { Equilibrium } \\
\text { temperature } \\
\left({ }^{\circ} \mathrm{C}\right)\end{array}$ \\
\hline $331-$ & & & \\
C0014F-1H & 4.2 & 4.33 & 21.69 \\
C0014C-1H & 6.5 & 4.41 & 22.75 \\
C0014G-1H & 9.2 & 4.62 & 15.72 \\
C0014D-2H & 16 & 4.69 & 55.15 \\
\hline
\end{tabular}

